

\title{
FORMULASI KEBIJAKAN PUBLIK : Studi Relokasi Pasar
}

\author{
AMTAI ALASLAN
}

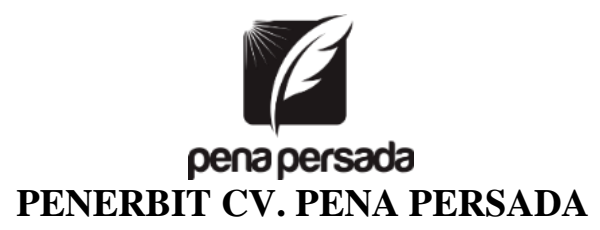




\section{FORMULASI KEBIJAKAN PUBLIK : \\ Studi Relokasi Pasar}

Penulis:

Amtai Alaslan

ISBN : 978-623-315-170-2

Design Cover :

Retnani Nur Briliant

Layout :

Nisa Falahia

\section{Penerbit CV. Pena Persada}

Redaksi :

Jl. Gerilya No. 292 Purwokerto Selatan, Kab. Banyumas

Jawa Tengah

Email : penerbit.penapersada@gmail.com Website

: penapersada.com Phone : (0281) 7771388

Anggota IKAPI

All right reserved

Cetakan pertama : 2021

Hak Cipta dilindungi oleh undang-undang. Dilarang memperbanyak karya tulis ini dalam bentuk apapun tanpa izin penerbit 


\section{KATA PENGANTAR}

Ucapan Syukur yang tiada hentinya Kepada Tuhan Yang Maha Esa atas cinta kasih dan pertolongan-Nya sehingga penyusun dapat menyelesaikan buku "FORMULASI KEBIJAKAN PUBLIK : Studi Relokasi Pasar".

Kajian dalam buku ini bertujuan untuk menjelaskan proses perumusan kebijakan Relokasi Pasar Talok di Jalan Tridarma Gendeng dengan melihat aktor-aktor yang berperan dalam kebijakan ini serta untuk mengetahui maksud dari kebijakan tersebut. Apa saja yang dilakukan pemerintah sehingga kebijakan relokasi ini dapat dilaksanakan dengan baik tanpa ada gejolak yang mengarah pada kekerasan.

Sektor informal khususnya pedagang kaki lima (PKL) dianggap oleh Pemerintah selalu menimbulkan masalah yang harus disingkirkan karena merusak keindahan kota, mengganggu ketertiban masyarakat, menyebabkan kemacetan lalu lintas, menimbulkan masalah kerawanan sosial dan kantong baru kekumuhan kota. Namun tanpa disadari sektor ini mempunyai peranan yang penting bagi pemerintah dalam penyerapan tenaga kerja dan dapat menambah devisa pemerintah lewat pajak dan retribusi yang dibayarkan. Untuk itu kebijakan yang dibuat oleh pemerintah harus benar-benar memperhatikan sektor informal tersebut.

Kebijakan ini diawali dengan adanya desakan dari masyarakat dan pemerhati kota yang menuntut untuk menata Pasar Talok yang banyak menimbulkan masalah. Kemudian Pemerintah Kota merespon aspirasi dari masyarakat tersebut dengan membuat kebijakan untuk merelokasi pasar tersebut. Dalam proses perumusan kebijakannya diawali dengan melakukan studi kelayakan terhadap pasar tersebut oleh Bappeda dan menyiapkan berbagai dokumen yang diperlukan untuk dibahas bersama para pedagang dan masyarakat yang banyak dibantu oleh LSM IMPLAW (Indonesia Monitoring Prosedure of Law). Setelah ada kesepakatan dari masyarakat dan pemerintah terhadap kebijakan ini maka selanjutnya kebijakan tersebut dibahas dengan Legislatif untuk dapat dilaksanakan. 
Dengan demikian maksud dari kebijakan relokasi ini adalah untuk memberikan perlindungan dan kenyamanan pada para pedagang dan pembeli serta masyarakat sekitar. Keberhasilan dari pelaksanaan kebijakan ini tidak terlepas dari berbagai tindakan preventif yang dilakukan oleh Pemerintah Kota Yogyakarta untuk menghindari konflik dengan pendekatan persuasif seperti dialog yang intensif setiap saat dan setiap kondisi yang dibutuhkan akhirnya para pedagang dan masyarakat dapat memahami maksud dari kebijakan tersebut.

Penyusun menyadari bahwa buku ini tidak akan terselesaikan dengan baik tanpa bantuan dari berbagai pihak. Oleh karena itu pada kesempatan ini perkenankanlah penyusun menghaturkan penghargaan dan ucapan terima kasih kepada semua pihak yang telah membantu penyusunan buku ini.

Semoga apa yang dihasilkan dari karya ini dapat bermanfaat bagi semua pihak meskipun masih jauh dari kesempurnaan, untuk itu sangat diharapkan kritik saran demi kempurnaanya di kemudian hari. Terima kasih. 


\section{DAFTAR ISI}

KATA PENGANTAR …......................................................... iii

DAFTAR ISI ....................................................................... v

BAB I

PENDAHULUAN ............................................................... 1

A. Perubahan Sistem Politik dan Pemerintahan.................... 1

B. Perumusan Kebijakan Publik .......................................... 3

C. Pembangunan Sektor Informal ....................................... 5

BAB II

SEKTOR INFORMAL DAN KEBIJAKAN PUBLIK .................... 10

A. Sektor Informal dan PKL .................................................. 10

1. Karakteristik Sektor Informal ...................................... 12

2. Sektor Informal dan Pengembangannya...................... 14

B. Pengertian Kebijakan Publik ............................................ 15

1. Konsep Kebijakan Publik ............................................. 16

2. Tahapan-Tahapan Kebijakan Publik ............................ 18

3. Pembuatan Kebijakan dan Perumusan Kebijakan......... 21

4. Tahapan Formulasi Kebijakan Publik ......................... 22

5. Model-model Formulasi Kebijakan Publik ................... 28

6. Formulasi Kebijakan Publik.......................................... 36

C. Kebijakan Publik Terkait Sektor Informal ......................... 39

BAB III

RASIONALISASI KEBIJAKAN RELOKASI PASAR .................. 42

A. Maksud Kebijakan Relokasi ................................................. 42

B. Karakteristik Kebijakan....................................................... 44

C. Eksistensi Jalan Tridarma ................................................. 50

D. Dinamika Sosial dan Politik .............................................. 53

BAB IV

AKTOR-AKTOR YANG TERLIBAT DALAM RELOKASI .......... 60

A. Ekekutif (Wali Kota) ........................................................... 60

B. Badan Perencanaan dan Pembangunan Daerah

(Bappeda) ...................................................................... 66 

C. Dinas Perindustrian, Perdagangan dan Koperasi (Disperindakop) 68
D. Dinas Pengelolaan Pasar (Dinlopas) ……………….....................69

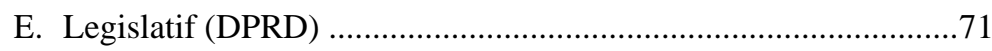

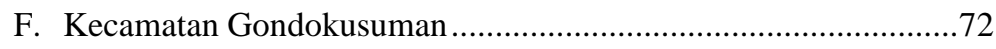

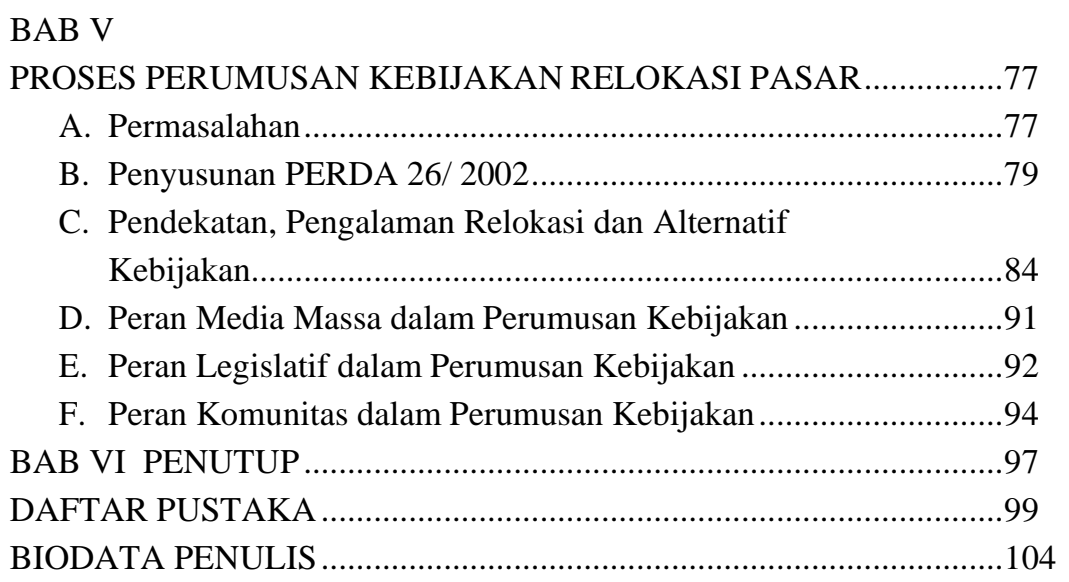





\section{BAB I \\ PENDAHULUAN}

\section{A. Perubahan Sistem Politik dan Pemerintahan}

Sejarah perjalanan pemerintahan Indonesia tidak terlepas dari Rezim pemerintahan Orde Baru yang berkuasa selama lebih dari 32 tahun. Dalam menjalankan pemerintahannya yang didasarkan pada ideologi developmentalisme (pembangunanisme) dengan mengedepankan pertumbuhan ekonomi sebagai aspek utama dan mengabaikan aspek yang lainnya seperti keadilan dll. Ciri khas yang melekat pada rezim ini adalah pendekatan keamanan, represifitas, perampasan terhadap hak-hak sipil, intimidasi terhadap gerakan-gerakan masyarakat sipil dan penyeragaman budaya serta institusi- institusi dalam masyarakat yang sangat heterogen. Partisipasi masyarakat dalam pentas politik sangat jarang bahkan tidak ada sama sekali karena yang terjadi hanyalah partisipasi semu dimana partisipasi masyarakat dalam politik hanya pemilihan umum.

Perubahan di tingkat lokal mulai tampak pada saat reformasi politik yang berhasil menggulingkan Soeharto dari singgasana kekuasaannya pada tahun 1998. Pada saat itulah terjadi pergeseran politik dalam peta politik nasional yang menuntut adanya perubahan yang mendasar dalam sistem pemerintahan Indonesia baik di tingkat nasional maupun pada tataran lokal. Tuntutan adanya demokratisasi dan desentralisasi dalam penyelenggaraan pemerintahan di tingkat lokal pun semakin tak terelakan lagi yang pada akhirnya menghasilkan perubahan yang sangat fundamental dalam tata pemerintahan daerah, dimana Undang-Undamg No 5 Tahun 1974 sebagai landasan regulasinya mengalami perubahan menjadi Undang-undang No 22 Tahun 1999 yang telah direvisi menjadi Undang-undang No 32 Tahun 2004. Dengan perubahan-perubahan tersebut menunjukkan bahwa 
pembenahan sistem pemerintahan daerah terus berjalan dinamis seiring dengan tuntutan dan aspirasi dari masyarakat (Hanif Nurcholis, 2005: 5).

Dari berbagai perubahan peraturan perundangan tentang sistem pemerintahan daerah tersebut, nampak bahwa asas desentralisasi kian mendapatkan kesempatan untuk dapat diimplementasikan. Pembenahan system desentralisasi ini sejalan dengan tuntutan demokratisasi di berbagai belahan dunia. Abdul Wahab mencatat bahwa pengaruh konsep desentralisasi itu sudah terlihat dengan semakin meluasnya tuntutan publik untuk mengadopsi gagasan demokratisasi di bidang pemerintahan mulai dari level nasional hingga level yang terendah. Catatan Bank Dunia juga memperlihatkan bahwa hampir sebagian besar Negara berkembang yang ada di belahan dunia ini sudah mempraktekan demokratisasi dan desentralisasi dengan menjalankan transfer kekuasaan politik ke unitunit politik di tingkat lokal (Abdul Wahab, 2002: 25).

Pada saat yang sama di luar struktur dan institusi pemerintahan telah muncul hasrat yang makin kuat untuk membudayakan demokratisasi dengan memberdayakan masyarakat sipil (civil Society). Keinginan ini terefleksi dengan adanya tuntutan untuk mengubah secara substansial dan fundamental pola hubungan politik yang semakin bercorak egaliter. Ini juga berarti bahwa dalam menjalani kehidupan bernegara dan bermasyarakat, selain ada ruang yang tersedia bagi bekerjanya sektor pemerintah, juga harus tersedia apa yang disebut oleh Habermas sebagai ruang publik (public sphere) bagi masyarakat yaitu ruang yang bukan hanya tersedia untuk melakukan interaksi sosial tetapi lebih dari pada itu merupakan ruang untuk berekspresi dan menyatakan pendapat, sekaligus sebagai sarana publik untuk mempengaruhi kekuasaan (Eddi Wibowo. 2004: 31).

Dilihat dari kebutuhan untuk membangun masyarakat yang mandiri, kokoh dan berdaya, maka adanya ruang publik itu jelas merupakan sebuah keniscayaan. Karena bagaimanapun luasnya ruang publik itu selalu dibayangi oleh 
represi Negara dalam kehidupan berpolitik dan berdemokrasi. Pada ruang publik itulah terbentang medan besar yang berisikan beragam institusi termasuk media dan kekuatan masyarakat lainnya, yang cukup lapang dan terbuka bagi publik guna membicarakan persoalanpersoalan yang dihadapinya secara bebas dan merdeka tanpa ada tekanan dari pihak manapun.

\section{B. Perumusan Kebijakan Publik}

Kebijakan publik sebagai salah satu instrumen pemerintah untuk menyelesaikan berbagai dinamika sosial dan politik yang ada dalam masyarakat. Dalam proses perumusan kebijakannya sangat kompleks karena menyangkut banyaknya kepentingan yang ada didalamnya, berbagai upaya harus dilakukan untuk mengakomodasi kepentingan-kepentingan yang berbeda tersebut. Selain kompleksitas subyek kebijakan yang sangat beragam, kompleksitas kebijakan juga menyangkut kepentingan pemangku kebijakan itu sendiri yang mempunyai rasionalisasi dan logika tersendiri (Budi Winarno, 2007: 20).

Secara umum, kebijakan publik terdiri dari berbagai lapis pemaknaan. Beberapa pemaknaan yang diberikan para ilmuwan terhadap kebijakan publik tak jarang justru mereduksi makna kebijakan itu sendiri. Ketika kebijakan publik hanya dimaknai sebagai proses decision making, maka kebijakan publik merupakan keputusan yang bersifat otoritatif, termasuk keputusan untuk membiarkan sesuatu itu terjadi, demi teratasinya suatu persoalan publik. Kebijakan juga sering dimaknai sebagai proses kerja dari para pembuat kebijakan publik sehingga kebijakan yang dihasilkan bersifat sangat teknokratis dan administratif. Kebijakan semacam ini bukan hanya sulit menjangkau kepentingan masyarakat yang sebenarnya tetapi bisa menjadi alat bagi para pemangku kebijakan untuk memenuhi kepentingan mereka sendiri. Lapis pemaknaan ketiga adalah kebijakan yang dimaknai sebagai bentuk intervensi sosio kultural dengan mendayagunakan berbagai instrumen untuk mengatasi persoalan publik. 
Sedangkan pemaknaan kebijakan yang paling kompleks adalah pemaknaan kebijakan sebagai interaksi negara dengan rakyatnya dalam rangka mengatasi persoalan publik (Joko Widodo, 2007: 14-15)

Pemaknaan kebijakan publik sebagai bentuk interaksi antara negara dan masyarakat akan membawa konsekuensi dalam implementasi dan proses pembuatan kebijakan semakin kompleks. Semakin dalam pemaknaan kebijakan publik, maka akan semakin banyak melibatkan aktor. Pelibatan aktor di luar pemerintah dalam pembuatan kebijakan sangat rentan terhadap konflik, sehingga kebijakan publik juga dimaknai sebagai proses pengelolaan konflik.

Disinilah yang merupakan tuntutan dari demokratisasi yang menghendaki adanya interaksi antar pemerintah dan masyarakat dalam merumuskan dan melaksanakan kebijakan publik sehingga tidak ada dominasi dan hegemoni dari kelompok yang satu terhadap kelompok yang lainnya. Untuk itu partisipasi masyarakat sangat penting dalam mewujudkan dan merumuskan kebijakan sehingga ada keselarasan dan kompromi bersama dalam menyelesaikan persoalan yang dihadapi, dalam konteks inilah yang sering dimaknai sebagai tersalurnya nilai-nilai governance (Pratikno, dkk, 2004: 43)

Sebagaimana yang dikatakan oleh beberapa ahli bahwa dalam merumuskan kebijakan publik itu tidaklah mudah seperti yang kita bayangkan karena melibatkan banyak aspek, proses serta berbagai macam variabel yang harus dikaji seperti yang dikatakan oleh Richard Rose bahwa kebijakan publik itu hendaknya dipahami sebagai sebuah rangkaian kegiatan yang sedikit banyak berhubungan langsung dengan konsekuensi- konsekuensinya bagi mereka yang bersangkutan (Budi Winarno, 2005: 67)

Kebijakan tidak hanya dipahami sebagai sebuah konsep intervensi pemerintah terhadap persoalan publik, tetapi harus dipahami sebagai proses interaksi. Dalam proses ini, terdapat mekanisme pembangunan konsensus antara kepentingan pemerintah dan masyarakat. Suatu interaksi yang ideal pasti 
melibatkan proses partisipasi dari masyarakat, akuntabilitas dari pemerintah dan proses aktualisasi kebijakan. Mekanisme tersebut dapat dipastikan akan melibatkan banyak pihak sehingga konflik menjadi keniscayaan.

\section{Pembangunan Sektor Informal}

Seiring dengan tuntutan zaman dan semakin kompleksnya pembangunan di satu sisi dapat meningkatkan pertumbuhan nasional namun di sisi lain harus bisa menghadirkan lapangan kerja kepada masyarakat. Dengan tantangan yang semakin berat, kesempatan untuk memperoleh pekerjaan di sektor formalpun semakin sulit.

Pada akhirnya pertumbuhan sektor informalpun semakin banyak karena modal yang dibutuhkan relatif kecil ditambah dengan adanya kemauan untuk bekerja maka pilihan untuk berusaha di sektor informal adalah salah satu solusinya.

Pertumbuhan sektor informal semakin meningkat dari tahun ke tahun yang menimbulkan persoalan yang serius bagi pemerintah Kota maupun Kabupaten. Hal ini tidak lepas dari proses urbanisasi penduduk dan migrasi penduduk yang disebabkan karena pertumbuhan ekonomi yang tidak merata di semua daerah. Sutoro Eko (2005: 95) mengatakan ruang-ruang ekonomi desa saat ini sangat terbatas, tidak lagi menjanjikan lapangan pekerjaan yang memadai karena itu sebagian besar generasi muda desa tidak lagi merasa nyaman (edhome) tinggal di desa, mereka melakukan urbanisasi ke kota-kota untuk mencari penghidupan yang lebih menjanjikan. Dengan harapan akan mendapatkan kehidupan yang lebih baik pada daerah yang di tujuh, namun kenyataan yang ada tidak seperti yang diharapkan akhirnya sektor informalah yang menjadi pilihan yang paling cepat dan nyaman untuk berusaha meskipun harus berhadapan dengan aturan yang dibuat oleh pemerintah setempat (Hartati, 2006: 64).

Sektor informal biasanya selalu dikaitkan dengan pedagang kaki lima (PKL) yang bayak disoroti karena masalah tempat kegiatan mereka berusaha/ berdagang. Namun disisi 
lain kegiatan kelompok ini merupakan penyerapan tenaga kerja terutama yang berpendidikan rendah dan juga penyerapan pendapatan daerah lewat retribusi yang dibayarkan. Usaha informal sebagian besar merupakan usaha pokok untuk menghidupi keluarganya. Hal ini membuktikan betapa berperannya sektor ini dalam mendukung penyerapan tenaga kerja dan sebagai usaha peningkatan kesejahteraan keluarga. Meskipun demikian pandangan pemerintah terhadap keberadaan PKL selalu menimbulkan masalah, mengganggu ketertiban, menyebabkan kemacetan dan yang lainnya, jarang sekali pemerintah berpandangan positif terhadap keberadaan sektor ini.

Sektor informal berkembang dengan cepat di Kota Yogyakarta, salah satunya adalah PKL yang keberadaannya tidak hanya di daerah dekat pasar dan sepanjang pertokoan tetapi di setiap jengkal trotoir atau jalan yang masih belum dimanfaatkan. Keberadaan PKL itu sendiri merupakan salah satu sumber lapangan pekerjaan dalam sektor informal yang disadari atau tidak sebenarnya keberadaanya menjadi kutub pengaman bagi kebutuhan masyarakat dalam penyediaan lapangan pekerjaan. Untuk itu salah satu kebijakan publik yang akan menjadi fokus kajian dalam kajian buku ini adalah kebijakan Relokasi Pasar Talok Gendeng. Kebijakan ini merupakan bagian dari upaya Pemerintah kota Yogyakarta dalam mengatasi permasalahan sektor informal. Sektor ini kian dinamis seiring dengan pertumbuhan ekonomi di bidang usaha sektor informal yang disertai dengan berbagai persoalan dan permasalahan yang ditimbulkan.

Menyadari akan begitu pentingnya peranan sektor ini maka Pemerintah Kota Yogyakarta mengeluarkan Peraturan Daerah (PERDA) Nomor 22 Tahun 2002 tentang keberadaan PKL di Kota Yogyakarta yang memuat tentang hak dan kewajiban PKL dalam melaksanakan usahanya. Keberadaan PKL itu pada dasarnya merupakan hak masyarakat untuk memenuhi kebutuhan hidupnya dengan berkewajiban menjaga dan memelihara kebersihan dan ketertiban serta menghormati 
pihak-pihak lain untuk mewujudkan lingkungan kota Yogyakarta yang rapi, bersih, indah, sehat dan nyaman.

Lahirnya regulasi ini dapat dipahami dari dua sisi yaitu disatu sisi regulasi ini merupakan penegasan terhadap kewajiban PKL untuk menjaga ketertiban dan keamanan serta menjaga hak-hak masyarakat dalam menggunakan fasilitas pemerintah. Disisi lain regulasi ini merupakan alat bagi pemerintah dalam melakukan pembinaan dan penataan terhadap PKL. Hal ini menegaskan bahwa bila dipahami dari sudut pandang yang lain, PKL bukanlah semata-mata pengganggu ketertiban umum seperti yang dipersepsikan namun justru dapat mengurangi beban pemerintah dalam menyediakan lapangan pekerjaan. Untuk itu penataan yang baik dari pihak pemerintah akan memudahkan berkembangnya perekonomian masyarakat.

Namun dalam perkembangannya keberadaan PKL di Yogyakarta dari tahun ke tahun semakin meningkat yang justru mengganggu ketertiban dan kepentingan umum. Hal inilah salah satunya terlihat pada Pasar Talok yang merupakan salah satu lokasi berkumpulnya PKL. Pasar ini terletak di Jalan Tridarma Gendeng, Kelurahan Baciro Kecamatan Gondokusuman Yogyakarta dimana keberadaannya terus mengalami perkembangan yang dikuatirkan akan semakin menyebabkan kemacetan pada jalan tersebut dan mengganggu ketertiban serta kebersihan lingkungan setempat sehingga harus dilakukan penataan terhadap pasar tersebut.

Perdagangan di jalan Tridarma Gendeng menimbulkan dampak bagi sektor lain terutama bagi masyarakat sekitar baik dari segi kebersihan lingkungan, disiplin lahan, ketertiban penempatan dagangan yang mengganggu lalulintas kendaraan dan pejalan kaki. Dengan demikian keberadaan pasar tersebut dipandang sebagai salah satu masalah dalam penataan dan pembangunan kota yang harus segera ditata untuk menghindari permasalahan yang lebih besar. 
Dengan berbagai permasalahan yang ditimbulkan dengan keberadaan Pasar Talok tersebut maka Pemerintah Kota Yogyakarta melakukan kebijakan penataan (relokasi) terhadap pasar tersebut ke tanah milik Pemkot yang masih kosong di perkampungan Gendeng samping jalan Tridarma yang berhadapan dengan lintasan kereta api. Kebijakan ini di tuangkan dalam Peraturan Walikota (Perwal) Yogyakarta Nomor : 31/DPA/SKPD/II/2007 tentang Dokumen SKPD untuk Penataan dan Pembangunan Pasar Talok. Dengan adanya kebijakan ini diharapkan dapat mengakomodasi kepentingan dari berbagai kelompok masyarakat tanpa saling merugikan sehingga dalam perumusan kebijakannya perlu memperhatikan masukanmasukan dari berbagai kelompok dan instansi yang terkait

Pada awalnya ketika wacana kebijakan relokasi ini digulirkan sejak tahun 2006 terjadi pro dan kontra terhadap kebijakan ini, namun kebijakan ini tetap dilaksanakan dan pada tahun 2010 dapat diimplementasikan dengan baik tanpa gejolak yang berarti di masyarakat maupun para pedagang. Tentunya kasus relokasi Pasar Talok ini sangat berbeda dengan kasus- kasus relokasi pada daerah lain yang sering kita saksikan lewat media massa dimana selalu terjadi bentrokan antara para pedagang yang menolak direlokasi oleh pemerintah setempat. Hal inilah yang menjadi salah satu persolan yang menarik diketahui proses pembuatan kebijakan dan perumusan kebijakannya serta siapa saja yang terlibat didalamnya.

Dengan demikian, kajian di buku ini difokuskan untuk menganalisis tentang proses formulasi kebijakan publik tersebut melalui studi kasus Pada Pasar Talok Gendeng. Kasus ini diambil terdapat banyak kepentingan dalam proses perumusan kebijakan publik tetapi berbagai kepentingan tersebut dapat diselaraskan sehingga tidak ada konflik pada saat kebijakan ini dilaksanakan. Kebijakan publik dalam kasus ini tidak hanya menyangkut level decision making pemerintah, namun terdapat proses administratif, intervensi dan bentuk interaksi antara pemerintah dan masyarakat.

Secara administratif, Pemkot telah merumuskan kebijakan relokasi dengan menyediakan berbagai bentuk insentif seperti tersedianya lahan baru dan kemudahan dalam hal sewa dan penempatan pedagang. Meskipun demikian, muncul persoalan ketika para pedagang menolak untuk direlokasi dengan berbagai alasan. Namun dengan berbagai pendekatan persuasif yang dilakukan dengan 
penuh kesabaran dalam melaksanakan kebijakan ini maka pada akhirnya kebijakan relokasi Pasar Talok ini dapat direalisasikan pada tahun 2010 dengan lancar tanpa ada gejolak di masyarakat dan para pedagang.

Persoalan relokasi biasanya selalu menimbulkan konflik kekerasan antara Pemerintah dan Masyarakat yang merasa digusur, namun hal tersebut tidak terlihat dalam kasus Relokasi Pasar Talok Gendeng di Jalan Tridarma. Inilah yang menjadi salah satu kasus yang menarik untuk diteliti yakni bagaimana proses perumusan kebijakan relokasi Pasar Talok Gendeng dilakukan. 


\section{BAB II \\ SEKTOR INFORMAL DAN KEBIJAKAN \\ PUBLIK}

Fenomena pedagang Pasar Talok merupakan bagian dari sektor informal yang selalu bertambah setiap tahun. Hal ini dapat menimbulkan masalah bagi ketertiban dan kenyamanan lingkungan di mana mereka berdagang serta bagai pengguna Jalan Tridarma. Keberadaan mereka merupakan masalah bagi masyarakat lain yang merasa hak-haknya terampas dengan keberadaan mereka. Kebijakan pemerintah kota dalam mereloksi pasar tersebut sangat menarik untuk dikaji lebih lanjut agar bermanfaat bagi semua pihak yang menginginkan keindahan, kebersihan dan kenyamanan kota.

Untuk itu mengetahui konsep dan bagaimana pengembangan sektor informal yang tentunya akan membantu dalam memahami kebijakan yang akan dibuat oleh actor-aktor pengambil kebijakan maka akan dibahas beberapa konsep yang terkait sebagai dasar pijakan dalam kajian ini. Selanjutnya mengetahui bagaimana kebijakan publik secara ideal seharusnya dirumuskan dan selanjutnya di implementasikan serta bagaimana kebijakan tersebut diformulasikan sehingga kita mendapatkan gambaran yang seharusnya dari kebijakan Relokasi Pasar Talok tersebut. Lebih jelasnya akan diuraikan dua konsep Dasar dengan berbagai subkonsepnya yaitu yang berkaitan dengan Sektor Informal dan Kebijakan Publik sebagai berikut :

\section{A. Sektor Informal dan PKL}

Swasono (1986: 33) menuliskan timbulnya sektor informal adalah akibat dari dualisme kegiatan ekonomi pada Negara-negara yang sedang berkembang seperti Indonesia, India, Brasil dan kebanyakan Negara Afrika lainnya. Di daerah perkotaan pada Negaranegara tersebut terdapat suatu aktifitas ekonomi yang tidak terorganisir dan tidak terjangkau oleh kebijaksanaan ekonomi pemerintah. Menurut Mubiarto sektor informal diidentikan dengan ekonomi kerakyatan orang kecil 
(wong cilik) yang dalam kegiatannya cenderung berkecimpung dalam kegiatan produksi ekonomi kecil-kecilan. Biasanya dilakukan oleh Petani, Nelayan, Peternak, Pengerajin, Pedagang Kaki Lima (PKL) dll. Sector ini sangat penting bagi masyarakat kecil dalam memenuhi kebutuhan hidupnya (Mubiarto dalam Sutoro Eko, 2005: 97)

Pakar ilmu sosial Mazumdar dalam (Subarsono 1998:84) mendeskripsikan sektor informal sebagai aktor yang tidak terproteksi/terlindungi (underprotected) dan sektor formal sebagai sektor yang terproteksi (proteceted). Untuk itu, Pemerintah Kota Yogyakarta dengan kebijakan relokasi Pasar Talok akan menjadikan mereka berdagang dengan status formal yang telah disediakan bangunan serta lahan bagi mereka untuk berdagang. Dengan diformalkan status mereka sebagai pedagang formal maka keberadaan mereka sudah sesuai dengan regulasi yang ada sehingga tidak akan digusur oleh pemrintah.

Hal itu senada dikatakan oleh De Soto (2006). Ia mengatakan bahwa persoalan di Negara berkembang yang menyebabkan ketertinggalan adalah tertutupnya mata pemerintah terhadap peraturan yang akomodatif untuk mendorong perkembangan dan kemajuan sektor informal. Terlihat dari definisi diatas bahwa Pemerintah Kota Yogyakarta tidak menutup mata terhadap keberadaan sector informal/PKL yang sudah dibuktikan dengan pengakuan eksistensi PKL lewat Perda 26/ 2002 tentang PKL yang pada dasarnya PKL merupakan hak masyarakat untuk memenuhi kebutuhan hidupnya dan berkewajiban menjaga kebersihan dan ketertiban serta menghormati pihak-pihak lain.

Atas dasar itulah maka Pemkot berusaha mendorong perkembangan dan kemajuan sektor informal yang salah satunya terlihat pada Kebijakan penataan Pasar Talok Gendeng Yogyakarta dengan mengeluarkan Peraturan Walikota (Perwal) Yogyakarta Nomor 31/DPA/SKPD/II/ 2007 tentang Dokumen SKPD untuk Penataan dan Pembangunan Pasar Talok agar 
para pedagang merasa aman dan nyaman dalam beraktifitas untuk mencari nafkah.

Pola kegiatan ekonomi perkotaan yang sifatnya kapitalistik cenderung menciptakan persaingan yang tidak seimbang terhadap usaha-usaha berskala kecil yang umumnya dilakukan oleh masyarakat golongan ekonomi lemah. Ketidak seimbangan ini akan menjadi lebih besar lagi apabila dikaitkan dengan terbatasnya sumber daya yang dimiliki (harta benda, keterampilan, permodalan dan informas) serta terbatasnya pilihan bagi masyarakat untuk memilih sektor informal sebagai alternatif lapangan pekerjaannya.

\section{Karakteristik Sektor Informal}

Dari penelitian yang dilakukan oleh para ilmuwan yang mengemukakan bahwa sector informal di Indonesia mempunyai ciri pokok yang bersifat kualitatif sebagai berikut :

a. Kegiatan usaha tidak terorganisasi secara baik, karena timbulnya unit usaha yang tidak mempergunakan fasilitas yang tidak tersedia di sektor formal.

b. Pada umumnya unit usaha tidak mempunyai izin usaha serta pola kegiatan usaha tidak teratur baik itu lokasi maupun waktu kerja.

c. Pada umumnya proteksi/ bantuan dari pemerintah untuk membantu ekonomi lemah tidak menyentuh sektor ini.

d. Unit usaha mudah keluar dan masuk dari satu sektor ke sub sektor lain

e. Teknologi yang dipergunakan bersifat primitif

f. Modal dan perputaran usaha relatif kecil, sehingga skala operasinya relatif kecil juga.

g. Tidak memerlukan pendidikan formal dalam menjalankan usaha tetapi yang diperlukan adalah pengalaman sambil bekerja.

h. Pada umumnya unit usaha termasuk golongan "one-manenterprise" dan kalau mengerjakan buruh berasal dari keluarga. 
i. Sumber dana modal usaha pada umumnya berasal dari tabungan sendiri atau dari lembaga keuangan tidak resmi.

j. Hasil produksi atau usaha terutama dikonsumsikan oleh golongan masyarakat kota/ desa berpenghasilan rendah dan kadang-kadang juga yang berpengalaman menengah (Emmanuel Subangun, 1991: 15).

Karakter yang khusus dari sektor informal tersebut diatas harus dikenali oleh pemerintah daerah manapun khususnya Pemerintah Kota Yogyakarta sehingga setiap kebijakan yang diambil sudah mempertimbangkan hal-hal tersebut. dengan demikian antisipasi sudah mulai dipikirkan sejak perumusan kebijakan yang akan dibahas untuk dijadikan landasan kebijakan publik.

Perbedaan karakteristik antara sektor informal dan sektor formal diklasifikasikan oleh Hidayat sebagai berikut :

Tabel 1. Perbedaan Karakteristik Sektor Formal dan Sektor Informal

\begin{tabular}{|l|l|l|}
\hline Karakteristik & Sektor Formal & \multicolumn{1}{|c|}{ Sektor Informal } \\
\hline Modal & $\begin{array}{l}\text { Relatif mudah } \\
\text { diperoleh }\end{array}$ & Sukar diperoleh \\
\hline Teknologi & Padat modal & Padat karya \\
\hline Organisasi & Birokrasi & $\begin{array}{l}\text { Menyerupai } \\
\text { organisasi keluarga }\end{array}$ \\
\hline Kredit & $\begin{array}{l}\text { Dari lembaga } \\
\text { keuangan resmi }\end{array}$ & $\begin{array}{l}\text { Dari kembaga } \\
\text { keuangan tidak resmi }\end{array}$ \\
\hline Serikat buruh & Sangat berperan & Tidak berperan \\
\hline $\begin{array}{l}\text { Bantuan } \\
\text { Pemerintah }\end{array}$ & $\begin{array}{l}\text { Penting untuk } \\
\text { kelangsungan } \\
\text { usaha }\end{array}$ & Tidak ada \\
\hline $\begin{array}{l}\text { Hubungan } \\
\text { dengan Desa }\end{array}$ & $\begin{array}{l}\text { One-way-traffic } \\
\text { untuk kepentingan } \\
\text { sektor formal }\end{array}$ & Saling menguntungkan \\
\hline
\end{tabular}




\begin{tabular}{|l|l|lr|}
\hline $\begin{array}{l}\text { Sifat Wiraswasta } \\
\text { (berdikari) }\end{array}$ & $\begin{array}{l}\text { Sangat tergantung } \\
\text { dari perlindungan } \\
\text { pemerintah }\end{array}$ & Berdikari \\
\hline $\begin{array}{l}\text { Persediaan } \\
\text { barang }\end{array}$ & $\begin{array}{l}\text { Jumlah besar } \\
\text { dan kualitas } \\
\text { baik }\end{array}$ & $\begin{array}{l}\text { Jumlah kecil dan } \\
\text { kualitas berubah- } \\
\text { ubah }\end{array}$ \\
\hline $\begin{array}{l}\text { Hubungan kerja } \\
\text { majikan- } \\
\text { buruh }\end{array}$ & $\begin{array}{l}\text { Berdasarkan } \\
\text { kontark kerja }\end{array}$ & $\begin{array}{l}\text { Berdasarkan aling percaya } \\
\text { sala }\end{array}$ \\
\hline
\end{tabular}

Sumber : Hidayat, (1978: 9)

\section{Sektor Informal dan Pengembangannya}

Skala prioritas pengembangan Kota Yogyakarta yang berpihak pada usaha skala makro telah menjadikan pengembangan sektor informal tidak berjalan dengan baik. Program penataan PKL mulai intensif dilakukan sejak tahun 2004. Bahkan konflik penataan muncul karena pedagang merasa terancam hidupnya. Dalam aksi 'Warga Yogyakarta Menuntut Keadilan, Tolak Penggusuran', oleh PK1 Angkringan Maliobordo dll (Republika, 09/03/2004) mereka menolak diadakan penataan karena penghasilan mereka menurun dengan dipindahkan ke lokasi baru.

Pengembangan sektor informal dalam ketentuan konsep pembangunan adalah pengembangan sektor informal menjadi satu kekuatan yang mampu mengarahkan perilaku hubungan yang lebih adil dengan sektor lain dan mandiri sebagai mana ditulis Swasono (1986: 47). Sementara itu Weeks dalam Burgers (1985: 15), menyebutkan bahwa perbedaan antara sektor informal dan formal yang membuat adalah pemerintah sehingga pemerintah memperlakukan kedua sector tersebut berbeda dengan mengembangkan perlindungan dan dukungan kewirausahaan kepada sektor formal sedang pada sektor informal dibiarkan bergerak di luar sistem. 
Pandangan pemerintah Kota Yogyakrta untuk pengembangan sector informal dengan pendekatan hubungan yang lunak secara efisien dan akan memperoleh nilai yang lebih bila diinvestasikan kembali secara tepat. Pada era otonomi daerah sekarang ini di mana peran masyarakat sangat penting dalam penyusunan kebijakan publik, sehingga kita akan melihat bagaimana kebijakan publik tentang Relokasi Pasar Talok tersebut dirumuskan. Cara pandang pelaku kebijakan terhadap sector informal akan mempengaruhi kebijakan yang akan diambil. Apakah hal itu merupakan hambatan dalam pembangunan kota atau merupakan sebagian solusi dari masalah yang kompleks di perkotaan.

\section{B. Pengertian Kebijakan Publik}

Secara etimologis, istilah kebijakan berasal dari Yunani, Sansekerta dan Latin. Akar kata dalam bahasa latin yaitu Polieta (Negara) dan akhirnya kedalam bahasa Inggris Pertengahan yaitu Police, berkenaan dengan pengendalian masalah publik dan administrasi. Asal kata Policy sama dengan kata lainya police dan politiks (Dunn dalam Muhajir Darwin 1990: 10)

Istilah kebijakan dalam bahasa Inggris 'policy' harus dibedakan dari kata 'kebijaksanaan' (wisdom) maupun kebajikan (virtues), karena sering kali pengunaan kata kebijakan dan kebijaksanaan digunakan untuk dengan maksud dan tujuan yang sama. Seringkali istilah Policy digunakan untuk istilah-istilah seperti tujuan (goals), program, keputusan, undang-undang, ketentuan-ketentuan, usulanusulan dan rancangan-rancangan besar (Wahab, 1997: 11-12)

Menurut Ealau dan Prewitt, kebijakan adalah sebuah ketepatan yang berlaku dan dicirikan oleh perilaku yang konsisten dan berulang, baik dari yang membuatnya maupun yang menaatinya. Kemudian Titmuss mendefenisikan kebijakan sebagai prinsip- prinsip yang mengatur tindakan yang diarahkan pada tujuan-tujuan tertentu, sehingga kebijakan itu senantiasa berorientasi pada masalah (problemoriented) dan berorientasi pada tindakan 
(action-oriented). Dengan demikian kebijakan adalah suatu ketepatan yang memuat prinsip-prinsip atau cara bertindak yang dibuat secara terencana dan konsisten untuk mengarahkan pengambilan keputusan dalam mencapai tujuan tertentu.

\section{Konsep Kebijakan Publik}

Istilah kebijakan publik (public policy) yang sering kita dengar dalam kehidupan sehari-hari baik dalam kegiatan perkuliahan akademis maupun dalam kehidupan politik dan pemerintahan. Menurut Robert Eyestone kebijakan public secara luas dapat didefinisikan sebagai 'hubungan suatu unit pemerintah dengan lingkungannya'. Konsep ini kelihatannya sangat luas dan menyangkut banyak hal, sehingga Thomas R. Dye memberikan salah satu batasan yang mengatakan bahwa kebijakan publik itu merupakan suatu 'pilihan oleh pemerintah untuk dilakukan dan tidak dilakukan'. Walaupun batasan ini agak tepat namun, tidak cukup untuk memberikan pembedaan yang jelas antara apa yang diputuskan oleh pemerintah untuk dilakukan dan apa yang seharusnya dilakukan oleh pemerintah (Budi Winarno, 2007 : 15).

Sementara itu Richard Rose menyarankan bahwa kebijakan publik itu hendaknya dipahami sebagai 'serangkaian kegiatan yang sedikit banyak berhubungan beserta konsekuensikonsekuensinya bagi mereka yang bersangkutan dari pada suatu keputusan sendiri'. Kelihatanya defenisi ini masih bersifat ambigu, namun dapat dipahami sebagai satu pola atau arah kegiatan dan bukan sekedar suatu keputusan untuk melakukan sesuatu. Lain halnya dengan Carl Friedrich yang melihat bahwa kebijakan publik itu sebagai 'Suatu usulan arah tindakan atau kebijakan yang diajukan oleh seseorang, kelompok, atau pemerintah guna mengatasi hambatan atau untuk memanfaatkan kesempatan pada suatu lingkungan tertentu dalam rangka mencapai suatu tujuan atau merealisasikan suatu sasaran'. Pandangan ini kelihatannya sudah menyangkut perilaku dari tindakan yang dilakukan oleh pemerintah, kelompok maupun individu tetapi definisi ini 
masih cukup luas tidak begitu mudah dipahami (Widodo C. Putro, 2009: 8)

Merujuk pada berbagai definisi mengenai kebijakan publik yang telah dijelaskan diatas maka dalam kajian ini dimaksudkan untuk memahami tentang posisi penting masyarakat dalam proses pembuatan kebijakan. Dalam pemahaman ini, kebijakan publik yang dibuat oleh pemerintah (kelompok-kelompok elit yang ada di dalamnya) diasumsikan sebagai dependent variabel yang dipengaruhi oleh interaksi sosial-politik yang ada di dalam masyarakat. Konsep Kebijakan inilah yang dimaknai oleh James Anderson sebagai 'suatu bentuk tindakan yang dilakukan dan ditetapkan oleh seorang aktor atau sekelompok aktor untuk mengatasi masalah atau persoalan yang dihadapi', di sinilah terjadi interaksi yang melibatkan aktor-aktor dalam proses perumusan dan pembuatan kebijakan publik.

Pemaknaan kebijakan publik sebagai bentuk interaksi antara negara dan masyarakat akan membawa konsekuensi bahwa implementasi dan proses pembuatan kebijakan tersebut akan semakin kompleks. Semakin dalam pemaknaan kebijakan publik, maka akan semakin banyak melibatkan aktor. Pelibatan aktor di luar pemerintah dalam pembuatan kebijakan sangat rentan terhadap konflik, sehingga kebijakan publik bisa dimaknai pula sebagai proses pengelolaan konflik.

Kebijakan tidak hanya dipahami sebagai sebuah konsep intervensi pemerintah terhadap persoalan publik, tetapi dipahami sebagai proses interaksi. Dalam proses ini, terdapat mekanisme pembangunan konsensus antara kepentingan pemerintah dan masyarakat. Suatu interaksi yang ideal pasti melibatkan proses partisipasi dari masyarakat, akuntabilitas dari pemerintah dan proses aktualisasi kebijakan.

Dengan demikian kebijakan publik adalah segala sesuatu yang dikerjakan oleh pemerintah dengan melihat berbagai persoalan yang ada di lapangan dan berusaha 
untuk mengatasinya dalam mewujudkan cita-cita kehidupan bersama yang lebih baik. Persoalan sektor informal di kota besar selalu menjadi agenda penting yang harus diselesaikan dengan bijak supaya tidak terjadi benturan kepentingan antara pemerintah sebagai regulator dan pedagang kaki lima sebagai obyek regulasi. Kebijakan pemerintah dalam melihat permasalahan dan merumuskan masalah akan berpengaruh terhadap kebijakan yang akan diambil terkait dengan keberadaan sektor informal terutama PKL.

Wibawa (2004: 283) menuliskan PKL adalah dilema karena di dalamnya tersimpan konflik kepentingan, nilai, ideologi atau apapun penyebutannya. Sudah menjadi karakter bagi setiap masyarakat, bahwa perbedaan ini bisa dipertemukan atau disinergikan sehingga menjadi suatu kekuatan progresif yang posistif, tetapi sebaliknya dapat pula menjadi benih konflik (seringkali fisik) yang bersifat reduktif terhadap kemajuankemajuan yang telah dicapai oleh masyarakat.

Menurut hampir semua ilmuwan, tidak ada cara yang lebih mujarab dalam mengelola konflik itu dari pada demokrasi yaitu semua pihak harus dipertemukan di sebuah meja bundar, dalam posisi yang sama dan sukarela tidak ada keterpaksaan dan pemaksaan, untuk berdebat dan meraih kompromi. Dengan kata lain, setelah kompromi dicapai haruslah diikuti dengan penegakan hukum, sehingga permasalahan kebijakan publik sendiri akhirnya berkaitan dengan keputusan seperti apa yang seharusnya tepat untuk ditetapkan sebagai bentuk perwujudan kebijakan yang ideal.

\section{Tahapan-Tahapan Kebijakan Publik}

Dengan melihat pada berbagai definisi dari para ahli tersebut diatas maka kebijakan publik itu tidak begitu saja lahir, namun melalui berbagai proses dan tahapan yang cukup panjang. Oleh karena itu beberapa ahli politik yang 
berminat pada proses perumusan kebijakan publik membagi proses-proses perumusan kebijakan publik ke dalam beberapa tahap. Tujuanya adalah untuk memudahkan kita dalam mengkaji kebijakan publik itu sendiri.

Anderson (1979) membedakan lima langkah dalam proses kebijakan yaitu Agenda setting, policy formulation, policy adoption, policy implementation dan policy assessment/ evaluasi. Sementara itu, Ripley membedakan proses kebijakan itu dalam empat tahapan yaitu : Agenda setting, formulation dan legitimation of goal and program, program implementation termasuk performance dan impact, serta decision about the future of the policy and program. Sama halnya, dengan Thomas R. Dye yang membedakan menjadi beberapa bagian utama yaitu Identification of policy, Agenda setting, policy formulation, legitimation of policies, policy implementation dan policy evaluation (Joko Widodo, 2007: 16)

Dari beberapa tahapan dalam kebijakan publik tersebut diatas pada umumnya terdiri dari empat tahapan utama yaitu :

a. Tahap Penyusunan agenda (Agenda Setting), pada tahap ini merupakan proses untuk membuat masalah publik itu menjadi masalah kebijakan, sehingga sangat perlu kecermatan dalam menilai dan mengkaji masalah yang muncul tersebut.

b. Tahap perumusan kebijakan (Policy Formulation), Pada tahap ini masalah yang telah masuk dalam agenda kebijakan akan dibahas oleh para pembuat kebijakan, di sinilah masalah itu akan dirumuskan menjadi salah satu pilihan alternatif dari berbagai alternatif yang ada untuk memecahkan masalah yang dihadapi. Tahap ini akan mengalami masalah yang cukup rumit karena akan melibatkan berbagai aktor dalam proses perumusannya sehingga berbagai kepentingan itu akan sulit disatukan jika tidak ada kompromi atau kesepahaman bersama untuk memecahkan masalah yang dihadapi. 
c. Tahap Implementasi (policy Implementation), Pada tahap ini, maka program yang telah dirumuskan dan diambil sebagai salah satu alternatif pemecahan masalah tersebut kemudian diimplementasikan atau dilaksanakan oleh badan-badan administrasi maupun agen-agen atau birokrasi pemerintah ditingkat bawah. Pada tahap berbagai kepentingan akan saling bersaing sehingga dalam pelaksanaannya ada yang mendukung maupun kadang pula mendapatkan penolakan dari berbagai pihak yang terkait.

d. Tahap Evaluasi kebijakan (Policy Evaluation), Pada tahap ini kebijakan yang telah dijalankan tersebut akan dinilai atau dievaluasi untuk melihat sejauh mana kebijakan itu mampu memecahkan permasalahan yang dihadapi. Dampak yang ditimbulkan dari kebijakan tersebut akan menjadi salah satu ukuran dalam proses penilaian dan evaluasi sehingga ada ukuran-ukuran tertentu yang menjadi dasar untuk melakukan evaluasi terhadap kebijakan tersebut. (Budi Winarno, 2007: 2830, bandingkan dengan Joko Widodo, 2007: 16-17)

Dengan melihat pada tahapan-tahapan dalam kebijakan publik yang tersebut diatas, maka penelitian ini hanya memfokuskan pada agenda setting dan proses perumusan masalah dari kebijakan relokasi pasar Talok tersebut. Tentunya tidak ada maksud sedikitpun dari kajian ini untuk menyepelekan tahapan yang lainya karena semua tahapan itu merupakan suatu proses yang tidak mudah dan begitu komleks sehingga dalam kaitannya dengan kebijakan relokasi Pasar Talok ini, maka penelitan ini hanya difokuskan pada proses formulasi kebijakannya dengan melihat interaksi antara aktor-aktor yang terlibat di dalamnya. 


\section{Pembuatan Kebijakan dan Perumusan Kebijakan}

Jika dilihat secara sekilas konsep pembuatan kebijakan dan perumusan kebijakan merupakan konsep yang hampir mirip, namun sebenarnya merupakan konsep yang sama sekali berbeda walaupun antara keduanya tidak dapat dipisahkan secara tegas. Proses pembuatan kebijakan publik melibatkan aktivitas pembuatan keputusan yang cenderung mempunyai percabangan luas, mempunyai perspektif jangka panjang dan penggunaan sumberdaya yang kritis untuk meraih kesempatan yang diterima dalam kondisi kesempatan yang berubah (Frank T. Paine dan William Naumes, dalam Budi Winarno, 2007: 68) Sementara itu menurut pandangan Tjokroamidjojo, dimana dibedakan antara policy formulating (perumusan kebijakan) mencakup proses pembuatan kebijakan (policy making) dengan konsepsi pengambilan keputusan (decision making).

Pengambilan keputusan (decision making) adalah pengambilan pilihan sesuatu alternatif yang bersaing mengenai suatu hal. Sedangkan pembuatan kebijakan (policy making) meliputi banyak pengambilan keputusan (decision making). Apabila pemilihan alternatif itu selesai dilakukan dan selesai, maka kegiatan itu disebut sebagai pengambilan keputusan (decision making), sedangkan jika hal yang sama dilakukan secara terus menerus maka disebut sebagai perumusan kebijakan (policy formulation), (Tjokroamidjojo dalam H.M. Safi'i, 2008; 88)

Disisi yang lain menurut Anderson perumusan kebijakan itu menyangkut upaya menjawab pertanyaan bagaimana berbagai alternatif disepakati untuk masalah- masalah yang dikembangkan dan siapa yang berpartisipasi didalamnya. Ini merupakan proses yang secara spesifik ditujukan untuk menyelesaikan persoalanpersoalan khusus. Sedangkan pembuatan kebijakan lebih merujuk pada aspek-aspek seperti bagaimana masalah-masalah publik menjadi perhatian para membuat kebijakan, bagaimana proposal kebijakan dirumuskan untuk masalah-masalah 
khusus, dan bagaimana proposal tersebut dipilih diantara berbagai alternatif yang saling berkompetisi, pembuatan kebijakan itu merupakan keseluruhan tahap dalam kebijakan publik yang berupa rangkaian keputusan.

\section{Tahapan Formulasi Kebijakan Publik}

Tahapan-tahapan proses kebijakan publik sebagaimana yang telah dikemukakan sebelumnya, biasanya secara teknis hanya dibedakan dalam tiga tahapan yaitu (1) Policy formulation, (2) Policy implementation dan (3) policy evaluation (Joko Widodo, 2007 :43). Sebagaimana yang telah dijelaskan sebelumnya bahwa penelitian ini hanya difokuskan untuk melihat tahap formulasi kebijakan relokasi pasar talok, maka dua tahapan lainya yaitu tahap implementasi dan tahap evaluasi tidak dijelaskan dalam kajian ini.

Tahap formulasi kebijakan ini merupakan tahapan yang sangat penting, manakala ini tidak dilakukan secara tepat dan komprehensif, maka hasil kebijakan yang diformulasikan tidak akan mencapai sasaran yang diharapkan secara optimal. Pada tahap ini paling tidak terdapat empat macam kegiatan atau tahapan yang harus dilalui yaitu : tahap identifikasi masalah, agenda setting, policy problem formulation dan tahap policy desing. Untuk lebih jelasnya dapat dijelaskan sebagai berikut :

a. Identifikasi masalah (Problem Identification)

Pada tahap ini dimaksudkan untuk lebih memahami dan mengenali permasalahan yang akan dijadikan sebagai dasar kebijakan. Untuk itu, langkah penting yang harus dilakukan adalah melakukan pemetaan situasi masalah dengan cara melakukan pencermatan atau mengenali setiap perubahan yang terjadi pada lingkungan. Salah satu metode yang digunakan untuk memahami masalah itu adalah dengan menggunakan iceberg theory atau teori gunung es. (Joko Widodo, 2007 :45) 
Menurut teori ini pemahaman terhadap masalah itu diawali dari adanya kejadian-kejadian (events) yang mengemuka di masyarakat, kemudian dari kejadian itu dapat dikemukakan apa yang menjadi kecenderungan atau pola perilaku (pattern of behavior) dari peristiwa itu. Atas dasar perilaku yang sama ini, kemudian bisa ditemukan apa yang menjadi struktur sistemis (systemic structure) permasalahan masyarakat tersebut, setelah itu dapat ditemukan akar permasalahannya (Mental models) yang merupakan kesimpulan dari peristiwa yang satu dengan yang lainya yang merupakan permasalahan masyarakat. Berdasarkan akar masalah itu, maka dapat ditentukan kerangka intervensi strategis (desain kebijakan) yang perlu dilakukan untuk mengatasi permasalahan itu.

b. Penyusunan Agenda (Agenda Setting)

Agenda setting adalah merupakan kegiatan untuk membuat masalah public (public problem) menjadi masalah kebijakan (policy problem). Agenda diartikan oleh Jones (1984) sebagai "a term commonly used to portray those issues judgel to require public action”. Artinya agenda adalah suatu istilah yang pada umumnya digunakan untuk menggambarkan suatu isu yang dinilai oleh publik perlu diambil suatu tindakan. Sementara itu, Darwin (1995) mengartikan agenda sebagai suatu kesepakatan umum, belum tentu tertulis tentang adanya suatu masalah publik yang perlu menjadi perhatian bersama dan menuntut campur tangan pemerintah untuk memecahkannya. (Joko widodo, 2007: 53).

Proses penyusunan agenda kebijakan menurut Anderson, secara runtut terdiri atas: : Private Problem, public problem, issues, systemic agenda, dan institusional agenda, (Ibidem). Dengan demikian penyusunan agenda diawali dari suatu masalah yang muncul di masyarakat, kemudian masalah itu dapat diungkapkan oleh seseorang sebagai suatu masalah pribadi (private 
problem). Masalah privat ini merupakan masalah-masalah yang mempunyai akibat terbatas atau hanya menyangkut satu atau sejumlah kecil orang yang terlibat secara langsung. Kemudian berkembang lebih lanjut menjadi masalah publik (public problem). Masalah public ini diartikan sebagai masalah yang mempunyai akibat yang luas, termasuk akibat-akibat yang mengenai orang- orang yang terlibat secara tidak langsung.

Dari masalah publik itu kemungkinan akan berkembang menjadi isu kebijakan (issues policy) yang diartikan oleh Jhon (1984) sebagai problema public yang saling bertentangan dan menimbulkan konflik satu sama lain (controversial public problem). Isu ini dapat pula diartikan sebagai perbedaanperbedaan pendapat di masyarakat tentang persepsi dan solusi (policy action) terhadap suatu masalah publik, sehingga isu kebijakan tidak hanya memandang ketidaksepahaman mengenai arah tindakan yang aktual dan potensial, tetapi juga mencerminkan pertentangan pandangan mengenai sifat masalah itu sendiri. Dengan begitu, isu kebijakan merupakan hasil perdebatan tentang definisi, klasifikasi, eksplanasi, dan evaluasi masalah (William Dunn, 1998: 97).

Isu kebijakan tadi kemudian akan mengalir masuk kedalam agenda pemerintah (government agenda) dan kemudian menjadi agenda kebijakan. Agenda pemerintah ini merupakan sejumlah daftar masalah dimana para pejabat publik menaruh perhatian yang serius pada waktu tertentu. Pada agenda pemerintah itulah yang oleh Cobb dan Elder dibedakan menjadi dua macam, yaitu agenda sistemik (systemic agenda) dan agenda institusional (institutional agenda).

Agenda sistemik ini merupakan semua isu yang pada umumnya dirasakan oleh para anggota masyarakat yang patut mendapat perhatian publik dan isu tersebut berada dalam yurisdiksi pemerintah, sementara itu. 
Sementara itu agenda institusional merupakan serangkaian masalah yang secara tegas membutuhkan pertimbanganpertimbangan yang aktif dan serius dari pembuat keputusan yang sah/otoritas (Joko Widodo, 2007: 55).

\section{c. Formulasi Masalah Kebijakan Publik}

Persoalan yang mendasar dalam merumuskan kebijakan publik sebagaimana yang telah dijelaskan sebelumnya adalah merumuskan masalah kebijakan (policy problem). Proses merumuskan masalah kebijakan ini menurut William Dunn dibedakan menjadi empat macam fase yang saling tergantung satu dengan yang lainnya yaitu: Pencarian masalah, Pendefinisian masalah, Spesifikasi masalah, dan Pengendalian masalah (Dunn, 1998: 244, bandingkan dengan Subarsono, 2005: 29)

Perumusan masalah diawali dengan adanya situasi masalah, yakni serangkaian situasi yang menimbulkan rasa ketidakpuasan dan terasa ada sesuatu yang salah kemudian dilakukan scanning (pengenalan masalah). Dari situasi masalah tadi kemudian dicari masalah, selanjutnya lahirlah peta masalah itu. Biasanya yang didapat adalah setumpuk masalah yang saling terkait yang belum terstruktur inilah yang kemudian disebut sebagai peta masalah.

Setumpuk masalah tersebut, dapat dipecahkan secara serentak, namun harus didefinisikan terlebih dahulu masalah mana yang menjadi masalah publik. Hasil dari pendefinisian setumpuk masalah yang belum terstruktur tadi menghasilkan masalah substansif yang kemudian dilakukan spesifikasi terhadap masalah substansif itu yang selanjutnya menghasilkan masalah formal, yakni masalah yang telah dirumuskan secara spesifik dan jelas. 
d. Mendesain Kebijakan (Policy Design)

Berdasarkan masalah kebijakan yang telah dirumuskan menjadi masalah formal tadi kemudian dicarikan solusi berupa kebijakan publik yang perlu diambil. Untuk menemukan kebijakan apa yang sebaiknya diambil perlu dilakukan analisis terhadap masalah kebijakan tersebut. Mustofadidjaja (2003) mengemukakan terdapat tujuh langkah (tahapan) dalam melakukan analisis kebijakan Yaitu :

1) Tahap Pengkajian Persoalan, tujuannya untuk menemukan dan memahami hakikat permasalahan yang berhasil diidentifikasi yang dihadapi oleh organisasi. Tahap ini menghendaki perlunya merumuskan masalah yang dihadapi oleh organisasi secara jelas dan tegas.

2) Tahap Penetapan Tujuan dan Sasaran Kebijakan, setiap kebijakan biasanya bertujuan untuk mencapai kebaikankebaikan lebih banyak dan mencegah timbulnya keburukankeburukan atau kerugian- kerugian semaksimal mungkin. Untuk itu tujuan dan sasaran intervensi kebijakan perlu ditetapkan terlebih dahulu jelas dan tegas, agar dapat dijadikan dasar pijakan dalam merumuskan alternatif intervensi apa yang diperlukan dan dapat dijadikan standar penilaian berhasil tidaknya langkah intervensi yang dilakukan. Jika kebijakan yang dibuat terhadap masalah yang diintervensi mampu mewujudkan tujuan dan sasaran yang hendak dicapai maka intervensi yang dilakukan itu berhasil, namun bila sebaliknya maka dapat dikatakan gagal.

3) Penyusunan Model, penyusunan model ini dimaksudkan untuk memudahkan analisis sekaligus memilih alternatif kebijakan intervensi mana yang harus dipilih. Setelah berhasil menetapkan model ini, tahap selanjutnya memilih alternatif kebijakan terhadap masalah yang dihadapi. 
4) Perumusan Alternatif Kebijakan, alternatif kebijakan ini merupakan sejumlah alat atau cara yang dapat dipergunakan untuk mencapai langsung tujuan dan sasaran yang telah ditetapkan pada tahap sebelumnya, di sinilah kita akan menemukan kemungkinan-kemungkinan yang akan muncul baik bersifat positif maupun negatif dari alternatif kebijakan yang telah ditetapkan. Setelah berhasil mengidentifikasi alternatif intervensi, tahapan selanjunya adalah memilih dan menetapkan alternatif kebijakan intervensi yang mempunyai peluang yang sangat besar untuk dapat mewujudkan tujuan dan sasaran dari masalah yang telah ditetapkan.

5) Penentuan Kriteria Pemilihan Alternatif Kebijakan, pada tahap ini akan ditentukan kriteria atau parameter apa yang dapat digunakan untuk memilih alternatif langkah apa yang perlu dilakukan. Di sinilah beberapa dimensi akan diperhatikan baik dimensi sosial, politik, ekonomi maupun budaya.

6) Penilaian Alternatif Kebijakan, tujuan penilaian alternatif ini adalah untuk mendapatkan gambaran lebih jauh mengenai tingkat efektifitas, efisiensi dan visibilitas dari setiap alternatif kebijakan yang diajukan untuk memecahkan masalah yang dihadapi.

7) Perumusan rekomendasi kebijakan, setelah diketahui alternatif kebijakan yang penilaiannya baik, langkah selanjutnya adalah menyusun rekomendasi alternatif kebijakan untuk masalah yang dihadapi. Pada tahap ini sangat diperhatikan hasil dari proses penilaian terhadap alternatif kebijakan yang dibuat sehingga aspek teknis yang meliputi aspek visibilitas efisien dan efektif dari berbagai dimensi baik secara ekonomis tidak terlalu banyak membutuhkan biaya, secara politik mempunyai dukungan yang kuat serta tingkat urgensi konfliknya relatif kecil serta secara sosial administratif mempunyai kemungkinan besar 
untuk dapat dilaksanakan. Jika penilaian terhadap alternatif kebijakan itu memperoleh dukungan yang baik dari masyarakat maka sebaiknya dijadikan sebagai alternatif kebijakan. (Joko Widodo, 2007: 71- 77)

\section{Model-model Formulasi Kebijakan Publik}

Sebagaimana dalam khasanah ilmu politik dan pemerintahan, proses pembuatan dan perumusan kebijakan itu merupakan sesuatu yang cukup rumit maka beberapa ahli mengembangkan model-model perumusan kebijakan publik untuk mengkaji proses perumusan kebijakan agar lebih mudah untuk dipahami. Model-model formulasi kebijakan ini tujuannya adalah : untuk menyederhanakan dan menjelaskan tentang pemerintahan dan politik, mengidentifikasi dan kepentingan dan kekuatan poltik dalam masyarakat, menjabarkan pengetahuan yang sesuai dengan kehidupan berpolitik serta menjelaskan permasalahan dan pengaruh politik yang terjadi. Begitu juga dengan kebijakan relokasi Pasar Talok, maka model-model formulasi kebijakan ini digunakan untuk menyederhanakan sekaligus untuk memahami proses formulasi kebijakan tersebut.

Berikut ini adalah beberapa model yang dikemukakan oleh Thomas Dye dalam Abdul Wahab (1997) yang membedakan beberapa model formulasi kebijakan yaitu Model Sisyem, Model Rasional, Model Inkremental, Model Elit dan Model Kelompok. Demikian halnya dengan model- model perumusan kebijakan yang dikemukakan oleh Yeheskel yang dikutip oleh Islami, dimana sebenarnya banyak persamaan dengan model yang dikembangkan oleh Dye antara lain : Pure rasionality model, economically rational model, Sequential decision model, Incrementality model, Satisficing model, Extra-rational model, Optimal model, Rasional comprehensive model serta Mixed-scanning model, (Dalam H.M. Safi'i, 2008; 89). 
Namun kajian yang dilakukan oleh Budi Winaro hanya mengelompokkan model-model formulasi kebijakan publik menjadi empat model yaitu Model Sistem, Model rasional, Model Inkremental dan Model Penyelidikan Campuran (mixedscaning), sementara model elitis dan kelompok menurut Thomas Dye di kelompokan ke dalam model-model analisis kebijakan publik (Winaro, 2007: 70)

Dengan melihat pada berbagai model yang telah dikemukakan tersebut, maka secara umum akan dibahas beberapa model perumusan kebijakan publik untuk memahami kebijakan relokasi pasar talok antra lain :

a. Model Rasional Komprehensif

Model ini merupakan model formulasi kebijakan yang memandang pencapaian tujuan secara efisien (policy as efficient goal achievement). Model ini diilhami oleh pendapat Herbert Simon dalam bukunya Administrative Behaviour yang menjelaskan tentang teori- teori administrasi yang harus menempatkan pengambilan keputusan sebagai pusat perhatian utamanya. Sebab tujuan suatu organisasi itu penting dalam mengarahkan perilaku administrasi, sehingga untuk mencapai tujuan suatu organisasi maka para pembuat keputusan rasional harus dihadapkan pada pilihan-pilihan yang tepat dari sejumlah alternatif- alternatif yang ada guna mencapai hasil yang di inginkan, (H.M. Safi'i, 2008: 94).

Sementara itu Budi Winarno mengatakan bahwa model ini merupakan model perumusan kebijakan yang paling terkenal dan juga yang paling luas diterima dalam kalangan pengkaji kebijakan publik. Pada dasarnya model ini dapat memudahkan pembuat keputusan jika dihadapkan pada suatu masalah tertentu. Masalah ini dapat dipisahkan dengan masalah-masalah yang lain atau paling tidak masalah tersebut dapat dipandang bermakna jika dibandingkan dengan masalahmasalah yang lain. 
Dari sini para pembuat keputusan memiliki alternatif beserta konsekuensi-konsekuensi yang memaksimalkan pencapaian tujuan, nilai atau sasaran- sasaran yang hendak dicapai. Keseluruhan dari proses tersebut akan menghasilkan suatu keputusan rasional yaitu keputusan yang efektif untuk mencapai tujuan tertentu (Budi Winarno, 2007: 75)

Dalam masyarakat sebetulnya tak ada nilai-nilai yang disepakati bersama, yang ada hanyalah beberapa nilai-nilai tertentu dari kelompok dan individu tertentu, sehingga nilainilai tersebut tidak bisa dibandingkan atau dilihat bobotnya. Hal inilah yang membuat adanya ketidakcermatan dalam menilai bobot nilai yang ada dalam masyarakat, sehingga tak jarang banyak ahli yang mengecamnya, bahkan ada yang menyebutnya tidak realistis. Meskipun demikian model ini tetap penting untuk digunakan dalam keperluan analisis, karena dapat membantu mengidentifikasikan hambatan-hambatan yang mungkin terjadi jika perumus kebijakan ingin menempuh pembuatan kebijakan yang rasional. (Lihat Winarno, 2002: 75 dan H.M. Safi'i, 2008; 95)

b. Model Penambahan (the Incremental Model)

Kritik terhadap model rasional komprehensif itu akhirnya melahirkan model penambahan atau incrementalisme yang bermaksud untuk menutupi kekurangan yang ada dalam model rasional dengan jalan menghindari banyak masalah yang ditemui dalam model rasional komprehensif. Model ini lebih bersifat deskriptif karena menggambarkan secara aktual caracara yang dipakai para pejabat dalam membuat keputusan. Ada beberapa hal yang harus diperhatikan dalam mempelajari model penambahan ini yaitu :

1) Pemilihan tujuan-tujuan atau sasaran-sasaran dan analisis empirik terhadap tindakan yang dibutuhkan, sehingga keduanya sangat berkaitan erat dan bukan berbeda satu dengan yang lain. 
2) Para pembuat keputusan hanya mempertimbangkan beberapa alternatif untuk menanggulangi masalah yang dihadapi dimana alternatif-alternatif ini hanya berada secara marginal dengan kebijakan yang sudah ada.

3) Untuk setiap alternatif, pembuat keputusan hanya mengevaluasi beberapa konsekuensi yang dianggap penting saja.

4) Masalah yang dihadapi oleh pembuat keputusan dibatasi kembali secara berkesinambungan, untuk itu inkremenlisme dibutuhkan untuk memungkinkan penyesuaian-penyesuaian sarana-tujan dan tujuan- saran sebanyak mungkin sehingga memungkinkan masalah dapat dikendalikan.

5) Tidak ada keputusan tunggal atau penyelesaian masalah yang dianggap tepat karena harus melewati berbagai macam analisis dalam rangka memecahkan persoalan yang dihadapi.

6) Pembuatan keputusan pada dasarnya hanya merupakan remedial dan diarahkan untuk lebih banyak melakukan perbaikan terhadap ketidaksempurnaan sosial yang nyata sekarang ini daripada mempromosikan tujuan sosial dimasa depan.

Lebih jauh model ini lebih mempertimbangkan pluralitas dalam pengambilan keputusan dan kebijakan sehingga merupakan hasil kompromi dan kesepakatan bersama antara banyak partisan. Dalam kondisi yang seperti ini, keputusan yang bijaksana akan lebih mudah mencapai kesepakatan apabila pesoalan-persoalan yang dipersengketakan antara berbagai kelompok dalam masyarakat hanya berupa perubahan-perubahan terhadap program yang sudah ada atau hanya menambah atau mengurangi anggaran belanja. Model ini sangat mempertimbangkan stabilitas dan kelangsungan 
dari sistem serta untung-ruginya, untuk menghindari hal itu maka yang dilakukan hanyalah melakukan perbaikan terhadap program yang sudah ada sebelumnya. Dengan demikian, pembuatan keputusan secara incrementalisme adalah penting dalam rangka mengurangi konflik, memelihara stabilitas dan sistem politik itu sendiri (James Anderson dalam Budi Winarno, 2007: 78)

Dengan melihat pada pandangan dari Aderson tersebut, maka sebetulnya model ini diarhkan bagi para pembuat keputusan dalam melaksanakan tugasnya, mereka berada dibawah keadaan yang tidak pasti karena berhubungan dengan konsekuensi-konsekuensi dari tindakan mereka di masa depan, maka keputusan incremental dapat mengurangi resiko atau biaya dari ketidakpastian itu.

Inkrementalisme juga mempunyai sifat yang realistis karena didasari kenyataan bahwa para pembuat keputusan kurang memiliki waktu, kecakapan dan sumber-sumber yang dibtuhkan untuk melakukan analisis yang menyeluruh terhadap semua penyelesaian alternatif dari masalah-masalah yang ada. Disamping itu, pada hakikatnya orang ingin bertindak pragmatis, tidak selalu mencari cara hingga yang paling baik dalam menanggulangi suatu masalah atau singkatnya inkrementalisme menghasilkan keputusan-keputusan yang terbatas, dapat dilakukan dan diterima.

c. Penyelidikan Campuran (Mixed Scaning)

Adalah Amitai Etzioni, seorang ahli sosiologi organisasi yang pertama kali menyodorkan model ini dengan pendekatan pengamatan terpadu (mixedsaning) sebagai salah satu pendekatan dalam pengambilan keputusan yang memperhitungkan baik kepeutusan- keputusan yang bersifat fundamental maupun keputusan yang bersifat inkremental, dan memberikan urutan teratas bagi proses pembuatan kebijakan fundamental yang memberikan arahan dasar proses- 
proses pembuatan kebijakan inkremental yang melapangkan jalan bagi keputusan-keputusan fundamental sesudah keputusan ini tercapai (Etzioni dalam Abdul Wahab, 1997: 24).

Ide pengamatan terpadu ini sendiri lahir dalam publikasi paper Mixed Scaning (1967), dan disusul dalam paper berikutnya the Active Society (1986), (Parson, 2005 dalam H.M. Safi'i, 2008; 96). Dalam pandangan Etzioni, keputusan yang dibuat para inkrementralis merefleksikan kepentingan kelompok-kelompok yang paling kuat dan teroganisisr dalam masyarakat, sementara kelompok-kelompok yang paling lemah dan tidak terorganisir secara politik diabaikan.

Disamping itu, dengan memfokuskan pada kebijakan-kebijakan jangka pendek dan terbatas, para inkrementalis mengabaikan pembaruan sosial yang mendasar.

Oleh karena itu gaya pembuatan keputusan dengan gaya inkeremntal cenderung menghasilkan kelambanan dan cenderung terpeliharanya status quo, sehingga merintangi upaya penyempurnaan proses pembuatan keputusan itu sendiri

(Budi Winaro, 2007:77)

Pendekatan ini, menurut Etzioni lebih meruapak "is" sekaligus "ought", dimana pendekatan ini berusaha mendeskripsikan tentang realitas starategi pembuatan keputusan seperti yang dipakai dalam berbagai bidang dan juga merupakan model untuk membuat keputusan secara lebih baik. Model ini mengakui bahwa para pembuat keputusan harus mempertimbangkan ongkos pengetahuan yaitu : tak semuanya bisa diamati, jadi para pembuat keputusan harus berusaha untuk mengamati area utama secara penuh dan "secara rasional", sedangkan area yang lainya hanya akan diamati secara "sepotong-potong"

Dengan demikian, penyelidikan campuran ini merupakan suatu bentuk pendekatan "kompromi" yang menggabungkan penggunaan inkrementalisme dan 
rasionalisme sekaligus, sehingga dapat mempromosikan "sebuah masyarakat yang aktif". Masyarakat aktif ini adalah masyarakat dimana orang-orangnya terdapat kolektivitas sosial, bisa lebih memahami diri mereka sendiri dan lebih mampu memformulasikan masyarakat sesuai dengan nilai-nilainya sendiri.

Namun demikian, eztioni tidak memberikan penjelasan yang cukup memadai tentang bagaimana pendekatan ini bisa digunakan dalam prakteknya. Walaupun begitu, pendekatan ini akan membantu mengingatkan kenyataan-kenyataan penting bahwa keputusan itu dapat berubah besar-besaran dan berbeda adalah wajar sejalan dengan sifat keputusan yang berubah-ubah tadi.

\section{d. Model Kelompok}

Model Kelompok sebagaimana ditulis Wibawa (1994: 9) merupakan abstraksi dari proses pembuatan kebijakan yang di dalamnya terdapat beberapa kelompok kepentingan yang berusaha untuk mempengaruhi isi dan bentuk kebijakan secara interaktif. Dengan demikian pembuatan kebijakan itu terlihat sebagai upaya untuk menanggapi tuntutan dari berbagai kelompok kepentingan dengan cara bargaining, negosiasi, dan kompromi. Tuntutan yang saling bersaing diantara kelompokkelompok yang berpengaruh akan dikelola dengan cara ini.

Sebagai hasil persaingan antara kelompok kepentingan, kebijakan negara pada hakekatnya adalah keseimbangan yang tercapai dalam pertarungan antar kelompok dalam memperjuangkan kepentingan masing- masing pada suatu waktu. Agar supaya pertarungan ini tidak bersifat merusak, maka sistem politik berkewajiban untuk mengarahkan konflik kelompok dengan cara : 
1) Menetapkan aturan main bagi kelompok-kelompok yang memperjuangkan kepentingan mereka

2) Mengatur kompromi dan menyeimbangkan kepentingankepentingan

3) Menuangkankompromi-kompromi tersebut sebagai kebijakan publik melaksanakan apa yang telah di kompromikan tersebut.

Kebijakan juga diartikan sebagai suatu tindakan yang mengarah pada tujuan yang diusulkan oleh seseorang, kelompok atau pemerintah dalam lingkungan tertentu sehubungan dengan adanya hambatan- hambatan tertentu, seraya mencari peluang-peluang untuk mencapai tujuan dalam mewujudkan sasaran yang diinginkan (Frederick dalam Wahap, 1997: 13). Dalam pengertian ini usulan kebijakan tidak hanya berasal dari pembuat kebijakan (pemerintah) tetapi dari kelompok yang ingin agar statusnya diperhatikan seperti halnya keberadaan pedagang Pasar Talok yang merasa tidak aman dan nyaman berdagang di lokasi yang sudah dilarang dalam Perda 26/2002 tentang PKL.

Dari berbagai pendekatan atau model-model formulasi kebijakan yang telah dibahas sebelunya, tentunya akan sangat membantu kita dalam mendeskripsikan dan menganalisis proses formulasi kebijakan Relokasi Pasar Talok. Tentunya dari proses yang telah berlangsung cukup lama itu hingga telah dibangunya bangunan sebagai tempat yang baru itu merupakan sebuah proses yang dinamis dan sangat sarat akan berbagai kepentingan yang mewarnai proses pengambilan keputusan tersebut sampai direalisasikan. Karena proses formulasi itu sendiri tidaklah semudah yang kita bayangkan seperti yang telah dibahas sebelumnya cukup rumit, maka dari berbagai pendekatan inilah yang akan digunakan dalam melihat dan mendeskripsikan kebijakan relokasi tersebut. 


\section{Formulasi Kebijakan Publik}

Persoalan pertama yang harus dilakukan dalam formulasi kebijakan publik (public policy formulation) adalah merumuskan masalah kebijakan (policy problem formulation) itu terdahulu. Islamy (1997) menegaskan bahwa hal yang lebih penting agar suatu masalah publik (public problem) bisa menjadi masalah kebijakan (policy problem) tidak cukup hanya dihayati oleh banyak orang sebagai suatu masalah tetapi masyarakat juga perlu memiliki political will untuk memperjuangkan masalah itu menjadi masalah kebijakan dan yang lebih penting lagi hal itu ditanggapi positif oleh pembuat kebijakan (Joko Widodo, 2007 : 51)

Dengan melihat pada apa yang dikemukakan oleh Islami, maka agar masalah publik tadi dapat dipecahkan dengan suatu kebijakan publik, sangat dinuntut adanya perumusan masalah dengan baik dan benar. Hal ini sesuai dengan apa yang dikemukakan oleh Ackoff (1974) bahwa keberhasilan dalam memecahkan masalah menghendaki ditemukannya pemecahan yang benar atas masalah yang benar. Kegagalan sering terjadi karena kita memecahkan masalah yang salah daripada mendapatkan pemecahan yang salah terhadap masalah yang benar, (William Dunn, 1998: 91).

Sebagaimana telah dijelakan sebelumnya, inti dari proses formulasi kebijakan publik adalah sautu tindakan dan interaksi di lingkungan masyarakat yang menghasilkan output (keluaran) dalam berbagai bentuk kebijakan. Guna mencapai tujuan agar kebijakan publik berhasil dengan baik maka diperlukan suatu cara atau teknik dalam pembuatannya atau perlu dilakukan perumusan kebijakan. Lindblom yang dikutip Abdul Wahab (1997: 16) mengatakan bahwa formulasi kebijakan bublik itu adalah :

"An extremely comlex, analitical and poltical proses to which there is no begging or end, and the boundaeies of which are most uncertain, somehow a complex set of forces that we call policy making all taken together, produces effects coled policies", (artinya, suatu proses yang sangat 
kompleks yang bersifat analitis dan politis yang tidak mempunyai awal dan akhir dan batas-batas dari proses tersebut pada umumnya tidak pasti, kadangkala rangkaian kekuatan-kekuatan yang kompleks yang kita sebut pembutan kebijakan itu menghasilkan suatu akibat yang kita namakan sebagai kebijakan).

Dalam formulasi kebijakan publik maka kompromi harus lebih diutamakan dan kepentingan bersama dan kesejahteraan bersama merupakan arah bagi tiap-tiap para perumus kebijakan publik. Setiap pejabat perumus kebijakan publik harus selalu peka dan dapat merasakan apa yang menjadi kebutuhan dan keinginan masyarakat. Setiap perumusan kebijakan negara atau apapun itu kebijakannya jika sesuai dengan kepentingan masyarakat maka pasti akan mendapat dukungan dari masyarakat.

Nakamura dan Smallwood yang (1997) menyatakan bahwa proses kebijakan itu akan mengalami siklus yang meliputi formulasi, implementasi dan evaluasi kebijakan. Untuk meraih keberhasilan dalam implementasi kebijakan maka formulasinya harus terarah dan tepat sasaran serta memahami kebutuhan publik yang berkembang saat itu. Dalam perumusan kebijakan publik pejabat yang bersangkutan perlu memperhatikan langka-langka berikut ini yang meliputi, proses perumusan masalah kebijakan publik, proses memasukan masalah ke dalam agenda pemerintah, perumusan usulan kebijakan publik, proses legitimasi kebijakan publik, pelaksanaan, penilaian sampai evaluasi kebijakan publik (H.M. Safi'i, 2008; 88).

Dalam banyak hal melakukan perumusan kebijakan publik bukanlah merupakan sesuatu hal yang mudah dilakukan oleh pejabat publik ataupun oleh aktor-aktor publik yang bersangkutan, karena proses perumusannya membutuhkan telah yang mendalam dan mendasar serta harus siap untuk bersinggungan dengan adanya benturan 
kepentingan dari kelompok lain yang tidak memiliki visi yang sama dalam suatu perumusan kebijakan publik.

Dilain pihak, kebijakan publik seringkali dibiat oleh suatu kelompok elit tanpa keikut sertaan anggota masyarakat. Tetapi sebaliknya, ada pula kebijakan yang dirumuskan tidak oleh sebuah elite penguasa melainkan oleh beberapa kelompok yang salin mempengaruhi. Isi suatu kebijkan yang dihasilkan baik secara elitis maupun partisipatif tersebut dapat bersifat pengulangan terhadap kebijakan pernah dibuat dan dapat pula bersifat radikal. Kebijakan dengan sifat kedua ini berarti kebijakan tersebut dibuat secara mendasar dengan pertimbangan yang rasional.

Bila diringkas kurang lebih perumusan kebijakan seperti yang tergambar dari bagan berikut ini

\section{Gambar 1. Proses Perumusan Kebijakan}

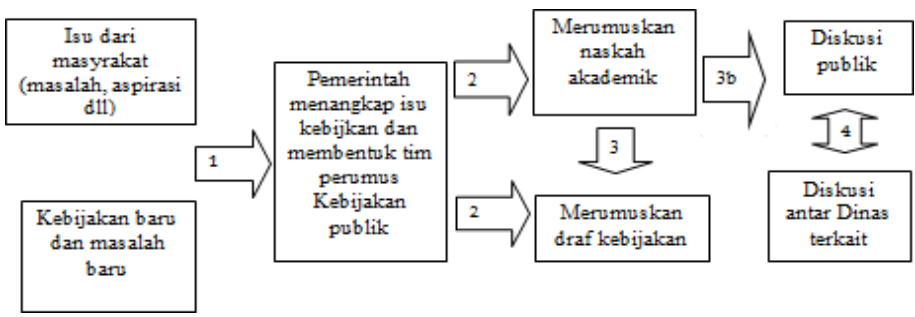

Sumber : Dwidjowijoto (2006: 111)

Membicarakan perumusan kebijkan publik adalah penting untuk melihat siapakah aktor-aktor yang terlibat dalam proses perumusan kebijakan tersebut. Setelah masalah-masalah publik diidentifikasi, maka langkah selanjutnya adalah bagaiman kebijkan bublik harus dirumuskan. Dallam tahap ini maka mengetahui siapa yang terlibat dalam perumusan kebijakan publik mereupakan sesuatu yang esensial. Hal ini karena siapa aktor yang terlibat dalam perumusan kebijakan publik akan menentukan sepeti apakah kebijakan tersebut akan dirumuskan (Winarno, 2007: 100). 
Setiap kebijakan seharusnya mengunkan pendekatan managemen sehingga tercipta penigkatan efisiensi, efektifitas, danperbaikan perekonomian sektor publik dengan menggunakan teknik-teknik yang pernah dianggap sebagai teknik yang cocok bagi sektor yang dihadapi. Ini semua tentunya tidak lepas dari pengalaman yang pernah dilakasanakan sehingga dapat dibuat managemen yang lebih baik dari kebijakan-kebijakan yang telah dibuat sebelumnya oleh Pemerinta Kota Yogyakarta seperti Relokasi Pedagang Shopping Center (2004), Relokasi Pedagang Klithikan (2007) dan berbagai kebijkan lainya untuk mengantisipasi dan dapat mengendalikan konflik yang akan terjadi.

\section{Kebijakan Publik Terkait Sektor Informal}

Subarsono (2006: 91) menyebutkan kebijakan alternatif terhadap sektor informal menurut McGee Yeung ada tiga modal yaitu kebijakan relokasi, kebijakan struktural dan kebijakan edukatif.

Kebijakan relokasi diseain untuk mengatur pola lingkungan yang pantas bagi beroperasinya sektor informal di perkotaan. Contoh yang jelas bagi kebijkan ini adalah sektor informal dilarang beropersi disuatau tempat tertentu atau pemindahan sektor informal dari lokasi yang satu ke lokasi yang lain seperti yang terjadi pada pada pedagang klitikan di Mangkubumi, alun-alun Kidul ke Pasar Pakucen dan juga Relokasi Pasar Talok dari Jalan Tidarma ke Kampung Gendeng agar lebih tertata dengan baik. Hal ini sejalan dengan Perda 26/ 2002 tentang PKL yang mulai intensif dilakukan sejak tahun 2003.

Sedangakan kebijakan struktural adalah adanya regulasi yang dibuat oleh pemerintah untuk membatasi ruang gerak mereka atau aturan-aturan yang mengikat ssuai dengan keberadaab mereka. Seperti kebijakan makro terkait ekonomi makro dan struktur keadilan ekonomi nasional. Kebijakan proteksi yang cenderung melindungi sektor formal sehingga perkembangan sektor informal tidak terkendali. Kebijkan 
ekonomi kerakyatan yang merupakan cara tercepat dan termudah untuk menciptkan pekerjaan bagi orang miskin, serta kebijkan formalisasi sektor informal yang bermaksud memberikan status legal terhadap aset yang dimiliki pelaku usaha sektor informal merupakan contoh dari kebijakan regulasi.

Adapun kebijakan edukatif dilakukan dengan adanya pelatihan manejemen, pwningkTn skill atau metoda pengelolaan produksi yang lebih modern ataupun pengorganisasian lembaga sektor informal agar lebih dapat eksis dan adanya peningkatan pendapatan. Pembinaan dan pelatiahan skill dilakukan Pemerintah Kota Yogyakarta dalam memndukung pengembangan sektor informal.

Hidayat (1978: 66) menuliskan relevansi pengembangan sektor informal sesuai dengan strategi pembagunan yaitu sebagai penyerapan tenaga kerja, menaikan taraf hidup golongan ekonomi lemah dan menampun migran di kota serta membeli kontribusi pendapatn regional. Sayangnnya unit usaha sektor informal tidak tercatat dalam lembaga yang bertugas mengumpulkan data karena tidak berijin. Hal ini berakaibat bila ada bantuan pemerintah yang bertujuan membantu golongan ini tidak dapat terjangkau sehingga proses mempertinggi kesempatan kerja dan percepatan pemerataan pendapatan keluarga terlambat.

Persepsi dan pandangan tentang sektor informal akan mempengaruhi bagaimana kebijakan tentang sektor ini dapat dirumusakan. Kesalahan dalam mendefenisikan dan melakukan interpretasi tentang sektor ini akan berdampak pada implementasi kebijkan yang diterapkan. Kemungkinan kesalahan pemerintah daerah dalam menata sektor ini yang didalammnya kebanyakan PKl adalah anggapan bahwa mereka sebagai hambatan yang harus disingkirkan. Etika bukan hanya sekedar memperbincangkan masalah baik dan buruk tetapi lebih pada keharusan setaip individu untuk bertanggung jawab atas apa yang diperbuat. Secara etis kebijakan sektor informal memperlohatkan adanya usaha untuk mengakomodasi 
kepentingan masyarakat dalam bidang ekonomi agar mereka dapat meningkatkan pendapatan.

Pemerintah Kota Yogayakarta menyadari adanya keterbatasan dalam menyediakan lapangan kerja pada sektor formal sehingga kebijakan yang dibuat sekarang ini lebih diprioritaskan pada sektor informal. Pemberian bantuan kredit lunak kepada kelomppk usaha kecil, pemberian pinjaman tenda untuk PKL, pemberian gerobak jualan bekerja sama dengan pihak ketiga serta kebijakan untuk merelokasi Pasar Talok untuk memberikan kenyaman kepada para pedagang adalah buktinya. Seluruh kebijakan tersebut tidak asal dibuat tetapi harus dirancang berkesinambungan untuk kualitas pelayanan yang lebih baik kepada masyarakat.

Dari berbagai landasan teori yang telah diuraikan tersebut diharapkan menjadi dasar pemahaman dalam menunjang keberhasilan suatu kebijakan dan sekaligus akan menjadi acuan bagi penulis untuk lebih mudah memahami dan membahas serta mengidentifikasi aktor yang terlibat dalam perumusan kebijakan tersebut, bagaimana pendekatan yang dilakukan oleh pemerintah sehingga kebijakan ini dapat dilaksanakan dengan baik tanpa ada konflik yang terjadi dimasyarakat. 


\section{BAB III RASIONALISASI \\ KEBIJAKAN RELOKASI \\ PASAR}

\section{A. Maksud Kebijakan Relokasi}

Di daerah perkotaan usaha sebagai pedagang kecil- kecilan atau pedagan kaki lima (PKL) merupakan salah satu jenis pekerjaan yang relatif khas dibandingkan dengan berbagai usaha pada sektor informal lainya, sama halnya dengan kondisi di Kota Yogyakarta yang masyarakatnya cukup banyak berusaha dalam bidang perdagangan. Sektor informal merupakan usaha berskala kecil yang memproduksi serta mendistribusikan barang dan jasa dengan tujuan pokok menciptakan kesempatan kerja dan pendapatan bagi dirinya masingmasing serta dalam usahanya dibatasi oleh faktor modal dan keterampilan. Inilah yang membuat sektor informal menjadi salah satu pilihan usaha bagi masyarakat ekonomi lemah untuk dapat memenuhi kebutuhan hidupnya (Hidayat, 1988: 53)

Keberadaan PKL merupakan realitas perekonomian kota, dimana keberadaan PKL di satu pihak memberikan keuntungan dalam menampung angkatan kerja yang ada namun di pihak lain dapat mengganggu dalam proses penataan kota. Dengan mempertimbangkan alasan tersebut maka pemerintah Kota Yogyakarta mengeluarkan Peraturan Walikota (Perwal) Nomor 31/DPA/SKPD/II/2007 tentang Dokumen SKPD untuk Penataan dan Pembangunan Pasar Talok sebagai bentuk kepedulian dari pemerintah untuk dapat meningkatkan ekonomi para pedagang pada pasar tersebut. Dengan dikeluarkannya aturan tersebut maka kebijakan untuk merelokasi para pedagang Pasar Talok yang berdada di Jalan Tridarama Kampung Gendeng Baciro ke bangunan yang akan disediakan oleh Pemerintah Kota dapat segera dilaksanakan. Kebijakan ini dimaksudkan selain untuk penataan kota juga untuk memfungsikan jalan Tridarma tersebut agar lalulintas 
kendaraan tidak mengalami kemacetan dan mobilitas pejalan kaki tidak terganggu.

Kebijakan untuk merelokasi para pedagang Pasar Talok dari jalan Tridarma merupakan salah satu usaha yang dilakukan dalam rangka untuk memberikan perlindungan pada para pedagang tersebut apabila turun hujan dan sekaligus untuk memperlancar lalulintas dan mobilitas penduduk setempat pada waktu pagi hari di jalan tersebut yang mengalami kemacetan akibat hampir sebagian bahu jalan digunakan untuk berdagang.

Apapun yang dilakukan pemerintah itu tidak semuanya direspon dengan baik oleh masyarakat dan para pedagang setempat, sehingga dengan mempertimbangkan hal-hal tersebut maka secara rinci maksud dari kebijakan relokasi ini dapat dijelaskan sebagai berikut :

1. Kebijakan ini merupakan perlindungan dan pemberdayaan bagi para pedagang dengan pengakuan terhadap keberadaan pedagang kaki lima di kota Yogyakarta.

2. Melakukan fasilitasi/pembinaan, pengaturan dan penertiban terhadap PKL.

3. Penanganan PKL dapat terkendali dengan menempati fasilitas yang telah disediakan oleh pemerintah.

4. Memperhatikan aspek-aspek ekonomi lemah yang terkait untuk dapat berkembang dan hidup sebagaimana mestinya dengan peningkatan sarana dan prasarana.

5. Penataan kota agar sesuai dengan semboyan Yogyakarta Berhati Nyaman sekaligus untuk membudayakan spirit dan semangat "Pasare resik rejekine apik".

6. Memudahkan masyarakat dalam memenuhi keperluan sehari-hari

7. Sistem pelayanan masyarakat yang disediakan oleh pemerintah dapat dimanfaatkan dan berguna bagi masyarakat secara optimal.

8. Mewujudkan sistem perkotaan Kota Yogyakarta yang seimbang, aman, tertib, lancar dan sehat (Anastasia R. Purnama Sari, 2004: $70)$. 
Namun ternyata tidak semua kebijakan yang di lakukan oleh pemerintah dapat dimengerti oleh masyarakat sebagai sesuatu yang bermanfaat. Untuk itu pemerintah terus melakukan berbagai upaya dengan melakukan sosialisasi, dan berbagai pendekatan persuasif lainya sehingga kebijakan ini dapat dimengerti oleh semua pihak. Hal inilah yang membuat kebijakan relokasi para pedagang pasar Talok ini membutuhkan waktu yang cukup lama untuk dapat di implementasikan.

\section{B. Karakteristik Kebijakan}

Ciri dan sifat suatu kebijakan yang akan di implementasikan dapat menentukan bagaimanakah pelaksanaan kebijakan tersebut. Sifat dari kebijakan yang dimaksudkan tersebut meliputi :

1. Ketersediaan dan Ketepatan Aloksi Sumber-sumber Kebijakan

Pada setiap tahap proses kebijakan harus dijamin tidak terdapat kendala pada sumber-sumber yang diperlukan, perpaduan diantara sumber-sumber tersebut harus benar-benar tersedia. Demikian juga dalam mengalokasikan sumber-sumber kebijakan kepada semua pihak yang memerlukannya harus benar-benar tepat dan sesuai dengan kebutuhan.

Sumber kebijakan yang dimaksud di sini adalah ketersediaan dan ketepatan alokasi sumber-sumber kebijakan relokasi para pedagang Pasar Talok Gendeng berupa waktu, tenaga dan dana.

Dari segi waktu, sejak diwacanakannya kebijakan ini pada tahun 2006 penyelenggaraan pertemuan ataupun rapat koordinasi yang diselenggarakan untuk membahas, merencanakan dan mengevaluasi langkah-langkah pelaksanaan dan pengaturan para pedagang sebelum direlokasi harus disediakan secara rutin oleh pihak yang terkait dalam hal ini Dinas atau Badan Pemerintah Kota Yogyakarta yang terkait. Sampai sejauh ini yang dilakukan 
secara rutin oleh pemerintah adalah penarikan pajak dan retribusi pasar dimana pajak pendapatan para pedagang ditarik satu tahun sekali, sedangkan retribusi dikenakan setiap harinya.

Sementara itu pengontrolan terhadap tempat-tempat yang jelas-jelas melanggar aturan, tidak ada tindakan yang jelas dan tegas. Dari keterangan para pedagang Pasar Talok, salah satunya mengemukakan bahwa petugas hanya mengemukakan jangan berjualan di devinder jalan (tengah jalan) hanya itu saja tidak ada petugas lain lagi yang menegur atau melarang para pedagang untuk berjualan" (Ibu Nunuk, Oktober 2010).

Hal ini sulit dilakukan karena tempat untuk berjualan adalah di tepi atau di pinggiran jalan Tridarma tersebut sehingga teguran itu tidak dapat dilaksanakan karena keramaian pembeli pada waktu pagi hari yang membuat kemacetan bahkan jalan tersebut tidak dapat dilalui oleh kendaraan bermotor. Dari uraian tersebut tentang penggunaan waktu yang disediakan oleh pemerintah sangat minim untuk melakukan koordinasi dalam penataan PKL. Selama ini waktu yang disediakan secara khusus untuk berdialog dengan para pedagang hanya terkait dengan rencana relokasi pasar tersebut.

Dari segi penggunaan tenaga, sebelum kebijakan relokasi ini dilaksanakan banyak sekali Dinas/ Badan pemerintah terkait seperti Dinas Pengelolaan Pasar, Dinas Ketertiban, Kebersihan yang mempunyai kewenangan untuk melakukan penataan terhadap PKL. Namun dalam kenyataannya pelaksanaan penyelenggaraan pengaturan pedagang kaki lima tidak optimal dilaksanakan, akibatnya semakin bertambahnya para pedagang yang berjualan di jalan Tridarma tersebut. Atas ketidak nyamanan masyarakat terhadap akses jalan tersebut maka sering kali yang disalahkan oleh masyarakat adalah pemerintah Kota. Minimnya koordinasi dari instasi pemerintah terkait membuat perkembangan pasar tersebut tidak dapat 
dibendung lagi oleh pemerintah sehingga alternatif solusinya adalah melakukan relokasi. Inilah yang perlu diperhatikan oleh pemerintah terkait dengan tenaga operasional di lapangan sehingga bangunan yang sudah disediakan tersebut harus benar-benar dimanfaatkan oleh para pedagang dengan baik dan benar.

Dari segi penggunaan dana, kenyataan bahwa banyaknya instansi yang terlibat dalam penataan kota khususnya penataan pasar dan pedagang kaki lima serta banyaknya para pegawai dalam instansi tersebut membuat alokasi dana dari pemerintah terkadang tidak mencukupi sehingga keefektifan dalam penataan pasar kurang optimal. Dengan rutinitas dari kewenangan instansi terkait dalam melakukan penertiban terhadap pedagang kaki lima tersebut sering membuat dana opersionalnya membengkak (A.R. Purnama Sari, 2004: 73)

Dengan direlokasikan pasar ini setidaknya dapat memberikan kontribusi terhadap penerimaan daerah lewat pajak dan retribusi pasar serta perparkiran, karena selama ini sebelum direlokasi penerimaan dari sektor tersebut sangat minim karena para pedagang tersebut belum diformalkan. Dari pendanaan ini perlu diperhatikan juga dana opersional yang diperlukan dalam pembangunan pasar baru tersebut agar jangan sampai membebani anggaran daerah namun hasil yang didapat dari penerimaan pasar baru tersebut tidak sesuai dengan pelaksanaan operasionalisasinya yang mengakibatkan terjadinya devisit anggaran biaya operasional.

2. Kejelasan dan Konsistensi Tujuan

Dalam proses pembuatan dan perumusan kebijakan sampai pada tahap implementasinya memerlukan pemahaman yang menyeluruh dari semua pihak, baik pemerintah dan masyarakat untuk mendapatkan sebuah kesepakatan terkait dengan tujuan dan sasaran yang akan dicapai dalam kebijakan tersebut. Tujuan harus dirumuskan 
dengan jelas dan spesifik serta akan lebih baik apabila dapat dirincikan sehingga dapat dipahami dan dapat disepakati oleh seluruh pihak yang terlibat di dalamnya untuk saling melengkapi, mendukung serta mampu berperan dengan baik.

Ketentuan-ketentuan harus diuraikan agar menjadi pedoman bagi para pedagang maupun semua pihak sebelum di relokasi. Untuk para pembuat kebijakan agar dalam membuat dan merumuskan kebijakan ini harus dapat dipastikan semua aspirasi yang ada sudah tersampaikan sehingga tujuan yang sudah ditetapkan dapat tercapai dengan baik. Dengan demikian maka dalam merumuskan kebijakan tersebut harus ada keterlibatan dari semua pihak yang terkait untuk saling melengkapi dan mendukung kebijakan ini.

Tujuan yang akan dicapai juga merupakan tujuan dari organisasi pelaksana dimana, dari satu sisi Pemerintah Kota memberikan kesempatan kepada masyarakat setempat untuk dapat meningkatkan kesejahteraannya melalui kegiatan perekonomian di sekitar pasar, namun di sisi lain harus memperhatikan upaya untuk menciptakan kondisi perkotaan yang aman, tertib dan sehat. Langkah-langkah untuk mencapai tujuan tersebut memerlukan suatu proses pembinaan dan kesadaran yang merupakan tugas dari organisasi pemerintah yang terkait.

Adanya konsistensi dari pemerintah dalam mewujudkan tujuan yang hendak dicapai dalam kebijakan relokasi Pasar Talok ini akan menjadi pedoman bagi para pedagang untuk dapat melaksanakan dan mematuhi kebijakan ini. Di sinilah pemerintah mempunyai peranan yang penting dalam memberikan pemahaman kepada masyarakat terkait dengan aktifitas dan keberadaannya di jalan Tridarma yang tidak memberikan kenyamanan terhadap pengguna jalan karena dipakai untuk berjualan. Konsistensi dari pemerintah dalam mewujudkan kebijakan ini harus dibuktikan dengan melakukan pendataan yang 
tepat sampai pada pembagian lapak pada pasar baru tersebut. Hal ini harus ditindak lanjuti dengan adanya persyaratan yang jelas mengenai ketentuan dan kewajiban dari para pedagang untuk berjualan di tempat yang baru tersebut.

\section{Rasionalisasi Kebijakan}

Keberadaan pedagang kaki lima dapat dipandang sebagai suatu hal yang menguntungkan tetapi juga dapat dipandang sebagai suatu hal yang menimbulkan permasalahan dalam penataan dan kebersihan kota. Ini juga yang menjadi sebuah pertimbangan pemerintah kota terhadap keberadaan Pasar Talok Gendeng yang menggunakan jalan Tridarma sebagai tempat untuk berjualan. Tentunya keberadaan pasar ini sangat mengganggu pengguna jalan tersebut pada waktu pagi hari sehingga upaya untuk mewujudkan kebersihan dan keindahan kota tidak efektif dilaksanakan.

Untuk mewujudkan penataan kota yang tertib, bersih dan sehat tersebut maka Pemerintah Kota membuat kebijakan untuk merelokasi para pedagang tersebut Kampung Gendeng yang lokasinya tidak jauh dari tempat sebelumnya, dimana Pemerintah Kota membuat sebuah bangunan permanen bagi para pedagang pasar tersebut di lahan milik Pemerintah Kota yang masih kosong dan belum dimanfaatkan. Bangunan baru yang disediakan oleh pemerintah tersebut di bangun dengan sumber pembiayannya berasal dari APBD pemerintah kota sehingga tidak memberatkan pihak manapun.

Dengan memperhatikan kebijakan tersebut maka pemerintah telah mempertimbangkan segala aspek dan kemungkinan yang akan terjadi sehingga terus diupayakan pendekatan dengan masyarakat sekitar dan para pedagang setempat untuk dapat mewujudkan kebijakan tersebut. Keterlibatan masyarakat dalam proses pembuatan dan perumusan kebijakan ini menjadikan kebijakan ini dapat 
dilaksanakan dengan baik, meskipun pada awal diwacanakan masyarakat dan pedagang setempat menolak untuk direlokasi.

Namun dengan berbagai upaya dan pendekatan yang dilakukan oleh pemerintah membuat kebijakan ini dapat diimplementasikan dengan baik, inilah sebuah kebijakan pemerintah kota yang cukup rasional karena menyediakan tempat yang permanen dan nyaman bagi para pedagang agar mereka terhindar dari panasnya terik matahari dan hujan yang sewaktuwaktu mengganggu aktifitas mereka.

\section{Latar Belakang Pembuatan Kebijakan}

Kebijakan yang dibuat itu mempunyai konsekuensi hukum dan mengikat semua orang, terlebih lagi apabila kebijakan tersebut dibuat oleh orang yang mempunyai kedudukan yang tinggi di dalam masyarakat, biasanya akan lebih ditaati jika dibandingkan dengan kebijakan yang dibuat oleh orang yang mempunyai kedudukan yang lebih rendah. Demikian juga bentuk dari kebijakan umum tersebut apakah itu dalam bentuk UU, Keppres, Perda atau Surat Keputusan, apabila maksud dan tujuannya baik untuk mewujudkan kesejahteraan masyarakat maka akan ditaati dan diikuti oleh masyarakat meskipun memerlukan waktu yang cukup panjang (A.R. Purnama Sari, 2004: 75).

Latar belakang dibuatnya kebijakan relokasi ini merupakan keprihatinan dan kepedulian dari pemerintah terhadap persoalan dan permasalahan yang dialami oleh masyarakat setempat. Permasalahan perkembangan pedagang yang semakin meningkat dalam menggunakan tempat pada daerah milik jalan secara tidak teratur, maka kebijakan ini dibuat untuk memberikan kenyamanan bagi semua pihak, baik itu pedagang, pengguna jalan, masyarakat setempat dan juga Pemerintah Kota Yogyakarta. 


\section{Eksistensi Jalan Tridarma}

Keberadaan pedagang kaki lima di Yogyakarta memang telah menjadi sorotan utama, hal tersebut bukan saja karena telah merampas hak pejalan kaki namun juga tidak sesuai dengan tata ruang dan penataan kota. Sama halnya dengan keberadaan PKL di Pasar Talok Kampung Gendeng yang jumlah sekitar 120 orang. Keberadaan pasar ini tidak lepas dari kehidupan dan dinamika masyarakat sekitar dalam mencari nafkah untuk kebutuhan hidupnya. Pada awalnya jalan Tridarma ini hanya digunakan oleh tujuh orang untuk berjualan sayuran dan jajanan yang di beli pada pasar terdekat seperti pasar Demangan dan Pasar Sentul, itu pun mereka berjualan bukan di tepi jalan Tridarma melainkan di depan rumah mereka sendiri namun dengan berjalannya waktu para pedagang semakin bertambah dan pasar tersebut semakin ramai dan menimbulkan persoalan yang serius bagi masyarakat pengguna jalan maupun bagi pemerintah sehingga keberadaannya harus ditata untuk menghindari kemacetan pada jalan tersebut.

Sebenarnya pemerintah kota telah memberikan teguran kepada para pedagang tersebut untuk sebaiknya berjualan pada pasar Demangan, namun hal tersebut dirasakan oleh para pedagang kurang menguntungkan karena selain belum tercatat sebagai pedagang permanen yang harus mempunyai kartu tanda pedagang (KTP) juga mereka harus mencari lokasi baru yang kemungkinan sulit untuk didapat pada pasar Demangan karena sudah terisikan oleh para pedagang pada pasar tersebut, lagi pula keberadaan mereka di jalan tersebut sudah diketahui oleh masyarakat sekitar sehingga mereka tidak perlu lagi mencari pelanggan baru apabila mereka pergi berjualan di Pasar Demangan. Dengan pertimbangan alasan tersebut maka para pedagang tetap memilih untuk berjualan di Jalan Tridarma yang sudah banyak diketahui oleh masyarakat sekitar. 
Kelangsungan pedagang di Jalan Tridarma Gendeng memang sekilas sangat menguntungkan karena kebanyakan para pembeli adalah masyarakat sekitar yang tidak perlu berbelanja ke pasar Demangan atau pasar Sentul yang harus menggunakan kendaraan bermotor, hanya dengan berjalan kaki mereka dapat berbelanja pada pasar Talok yang lebih dekat. Namun sebenarnya para pedagang juga harus merasa was-was kalau sewaktu-waktu mereka harus dipaksakan untuk pindah karena status mereka yang belum menjadi pedagang formal. Para pedagang juga harus was-was terhadap gejala alam yang tidak menentu apabila terjadi hujan angin dan badai maka mereka akan sangat kerepotan karena keberadaan mereka di jalan tersebut yang tidak terlindungi dengan bangunan permanen sebagai tempat berjualan.

Beberapa pedagang juga sadar bahwa sebenarnya tempat yang mereka pakai berjualan itu adalah jalan raya, tetapi karena sudah banyak teman yang berjualan pada jalan tersebut maka mereka ikut juga untuk berjualan. Beberapa pedagang mengakui mereka juga membayar retribusi sebesar Rp. 300/ hari ditambah dengan uang kebersihan sehingga setiap harinya mereka harus membayar uang untuk petugas sebesar Rp. 500. Tempat berjualan mereka juga sebenarnya sudah paten dalam arti setiap harinya mereka berada di tempat tersebut untuk berjualan dan sudah membeyar uang retribusi setiap harinya.

Sesuai dengan Peraturan Daerah (Perda) Kota Yogyakarta Nomor 3 tahun 1992 yang telah diperbaharui dengan Perda Nomor 03 tahun 2009 tentang Pasar bahwa dengan berkembangnya perekonomian telah memacu timbulnya keanekaragaman fungsi dan sifat pasar baik yang dikelola oleh Pemda maupun pihak ketiga di wilayah kota Yogyakarta. Pasar adalah suatu lahan pada lokasi yang ditentukan oleh kepala daerah tanpa atau dengan bangunan dengan batas-batas tertentu dan dipergunakan para penjual dan pembeli untuk tempat jual-beli dan atau melakukan pekerjaan jasa secara langsung dan atau tidak langsung dalam 
suatu sistem pengelolaan baik oleh Pemda maupun oleh pihak ketiga dan atau kerja sama antara keduanya.

Pihak ketiga adalah instansi atau badan usaha dan atau perseorangan yang berada diluar organisasi Pemerintah Daerah antara lain Pemerintah Pusat, Pemerintah Daerah lainnya, Badan Usaha Milik Negara (BUMN), Badan Usaha Milik Daerah (BUMD), Koperasi, Swasta Nasional, dan atau Asing yang tunduk pada hukum Indonesia. Dengan demikian secara jelas bahwa perdagangan di Jalan Tridarma bukan merupakan area Pasar. Hal tersebut dapat dilihat pada Perda No 03 tahun 2009 dimana pasar-pasar yang ada di wilayah kota Yogyakarta terbagi dalam pasar umum dan pasar khusus yang di dalamnya tidak terdapat Jalan Tridarma sebagai sebuah areal pasar.

Tentu saja kebijakan dari pemerintah untuk merelokasi para pedagang pasar Talok ini bukan berarti harus di gusur tetapi memberikan peluang tempat usaha yang sesuai dan memadai untuk berdagang, meskipun kebijakan ini mempunyai dampak yang berarti. Upaya dari pemerintah ini tentu saja akan membawa perubahan terhadap pola perdagangan dimana para pedagang tersebut harus bersaing untuk menjajakan dagangannya. Sebagian besar para pedagang Pasar Talok adalah penjual sayur, buah-buahan, dan berbagai jenis jajanan lainnya serta mainan anak-anak. Dengan dengan direlokasinya pasar tersebut maka pembeli yang pada awalnya lebih suka untuk berbelanja di jalan harus masuk kedalam pasar untuk berbelanja.

"Salah satu pembeli mengatakan bahwa dengan dipindahkannya pasar ini kedalam sebuah bangunan maka akan cukup merepotkan bagi kami untuk bernelanja karena pada awalnya pasar ini hanya didepan rumah saya sehingga tidak kerepotan tetepi dengan lokasi pasar yang sekarang, saya harus berjalan cukup jauh atau bahkan kalau perlu dengan motor yang harus membayar parkiran lagi untuk berbelanja di pasar tersebut" (wawancara dengan Ibu Lina). 
Permasalahan dari para pedagang yang berjualan di Jalan Tridarma ini bukan hanya masalah ketertiban atau masalah penataan kota semata tetapi juga merupakan masalah perut, karena para pedagang tersebut bekerja untuk memberikan nafkah bagi keluarganya. Dengan demikian maka kebijakan untuk merelokasi para pedagang tersebut harus benar-benar memastikan dan menjamin bagi para pedagang tersebut bahwa mereka akan tetap mendapatkan hak yang sama pada lokasi baru mereka. Pemerintah harus bisa menjamin untuk pertumbuhan dan perkembangan perekonomian masyarakat lemah seperti yang dihadapi oleh para pedagang tersebut sehingga dengan sendirinya kepercayaan (trust) dari masyarakat terhadap pemerintah tetap terjaga dan terpelihara.

\section{Dinamika Sosial dan Politik}

Aktifitas Perdagangan di jalan Tridarma Pasar Talok merupakan sebuah usaha yang ilegal bagi pemerintah akan tetapi bagi masyarakat setempat merupakan satu pusat kegiatan ekonomi yang sangat bermanfaat serta menjanjikan. Dengan keberadaan pasar tersebut maka selain menguntungkan bagi para pedagang juga akan lebih memudahkan masyarakat setempat untuk berbelanja karena mudah dijangkau. Kondisi kehidupan perdagangan di Pasar tersebut memang sangat kompleks apabila kita mengamatinya lebih jauh sebelum direlokasi, hal tersebut dapat terlihat pada waktu pagi hari ketika kita melewati jalan tersebut maka yang akan kita lihat adalah kemacetan karena hampir semua ruas jalan Tridarma tersebut digunakan untuk berjualan. Dengan alasan kemacetan dan ketertiban inilah yang dijadikan dasar pertimbangan oleh pemerintah untuk merelokasi para pedagang tersebut.

Adapun faktor-faktor yang mempengaruhi kebijakan reloksi Pasar Talok di Jalan Tridarma ini yaitu : 


\section{Faktor Sosial}

Dukungan dan kesadaran dari masyarakat, pedagang dan semua pihak terhadap kebijakan ini akan sangat membantu dalam pelaksanaan kebijakan tersebut. Oleh karena maksud dari kebijakan ini adalah untuk memberikan perlindungan dan pemberdayaan kepada masyarakat dan para pedagang itu sendiri maka dukungan masyarakat sangat diharapkan. Adanya kesepahaman dan saling pengertian antara pemerintah dan masyarakat akan memperlancar kebijakan yang dibuat tersebut.

Dukungan dari masyarakat akan berpengaruh terhadap implementasi kebijakan, karena munculnya isu- isu kebijakan tersebut dapat bersumber dari perhatian dan kepedulian masyarakat atau publik terhadap fenomena tertentu atau yang dialami dan dirasakan secara langsung. Dukungan masyarakat untuk mengimplementasikan suatu kebijakan diperlukan secara terus menerus, karena apabila perhatian publik hanya bersifat sesaat maka akan menyebabkan berkurangnya kesungguhan dari unit-unit atau badan-badan pelaksana dalam proses pembuataan kebijakaan tersebut (A.R. Purnama Sari, 2004: 82).

Sikap dan perilaku masyarakat inilah yang akan menentukan arah dan tujuan dari pembuatan kebijakan tersebut untuk dapat diimplementasikan atau tidak. Karena bagaimanapun bagusnya atau tidaknya suatu kebijakan kalau tidak direspon dengan baik oleh para pedagang maka akan mempersulit implementasi kebijakan tersebut dan tentunya akan menimbulkan permasalahan baru lagi.

Kesadaran para pedagang sebagai suatu individu mungkin akan berbeda dengan kesadaran pedagang sebagai sebuah kelompok dalam memahami kebijakan yang dibuat oleh pemerintah. Tingkat pemahaman sebagai individu mungkin sangat dipengaruhi oleh tingkat pendidikaan ataupun kepedulian individu terhadap kebijakan yang dibuat tersebut. Acap kali para pedagang sebagai individu tidak mempedulikan apa yang dilakukan 
oleh pemerintah, mereka beranggapan tidak ada pengaruhnya dengan kehidupan mereka. Sebagai individu yang tingkat kepeduliannya sangat tinggi terhadap kebijakan yang dibuat maka dia akan selalu mengikuti perkembagan dari kebijakan yang dibuat tersebut.

Lain halnya dengan pemahaman pedagang sebagai sebuah kelompok atau komunitas terhadap kebijakan yang dibuat. Sebagai sebuah kelompok maka akses dan pengetahuan terhadap kebijakan tersebut jauh lebih tinggi karena pemerintah cenderung lebih banyak melibatkan sebuah kelompok atau komunitas dalam pebuatan sebuah kebijakan, disinilah peran pemimpin kelompok dalam memberikan pemahaman dan informasi bagi anggota kelompoknya. Dengan memahami dan mengetahui kebijakan yang dibuat tersebut oleh kelompok sasaran maka akan direspon dengan baik.

Inilah beberapa para pedagang yang merespon kebijakan relokasi pasar tersebut.

Ny. Nunu pedagang buah yang mengatakan bahwah :

"Saya sudah mengetahui pasar ini akan direlokasi dari jalan ini tetapi sejauh ini saya tidak mengetahui proses pembuatan kebijakan tersebut, saya hanya matur aja wong semuanya untuk kebaikan kita ko maksudnya pedagang”

Lain halnya dengan Bapak Tono salah seorang pedagang ayam dan ikan yang mengatakan bahwa :

"Jauh sebelumnya ia telah diberitahu oleh pemerintah bahwa mereka akan direlokasi ke sebuah bangunan yang akan disediakan oleh pemerintah untuk ditempati. Informasi ini diketahui pada saat mengikuti sosialisasi dari pemerintah kecamatan Gondokusuman"

Ini menunjukan bahwa pemahaman dan kepedulian para pedagang terhadap kebijakan yang dibuat oleh pemerintah sangat sangat bervariasi, namun dengan adanya kepedulian terhadap kebijakan ini maka akan sangat 
berguna dalam proses perumusan dan implementasi kebijakan tersebut.

2. Faktor Ekonomi

Ekonomi merupakan salah satu aspek yang perlu dipikirkan dalam pembuatan kebijakan yang berdampak pada masyarakat luas, ekonomi di sini menyangkut dagang dan kesempataan. Kesempatan agar masing-masing pihak mendapatkan keuntungan baik itu pembeli ataupun penjual. Karena dalam sebuah pasar persaingan yang terjadi di dalamnya sangat kompetitif. Sektor inilah yang menjadi salah satu pendorong awal pemulihan ekonomi dimana sektor ini mempunyai peranan dalam pemenuhan konsumsi masyarakat serta sektor yang memiliki nilai tambah lokal yang tinggi (Propenas Tahun 2004 dalam Purnama Sari, 2004: 84).

Dengan struktur perekonomian kota Yogyakarta yang sangat didominasi oleh sektor perdagangan yang sangat beragam menjadikan masyarakat lebih respek terhadap sektor ini untuk berjualan dan mencari nafkah. Usaha yang dilakukanpun harus tetap dalam lingkup peraturan yang berlaku, sehingga sering kali kebijakan yang dibuat tersebut ditanggapi secara beragam oleh masyarakat baik itu yang positif maupun negatif.

Beragamnya respon masyarakat dan para pedagang Pasar Talok terhadap kebijakan ini sangat dipengaruhi oleh dinamika sosial dan politik yang menyertainya. Hal ini tidak lepas dari corak dan budaya kehidupan masyarakat yang sudah ada sejak dulunya dalam menyikapi berbagai persoalan yang dihadapi.

a. Dinamika Politik

Kebijakan relokasi pedagang Pasar Talok dari jalan Tridarma pada awalnya diwacanakan pada tahun 2006. Namun dengan mempertimbangkan aspirasi dari para pedagang setempat yang pada waktu itu menolak untuk direlokasi maka pemerintah Kota melalui Kecamatan Gondokusuman mengajak masyarakat dan para 
pedagang untuk berdiskusi sekaligus mensosialisasikan kebijakan relokasi tersebut. Dalam pembahasan yang dilakukan oleh pemerintah tersebut, masyarakat dan para pedagang tetap menolak untuk direlokasi. Para pedagang setempat menolak untuk direlokasi dengan berbagai alasan, ada yang mengatakan bahwa dengan adanya kebijakan ini maka mereka akan kehilangan haknya sebagai pedagang, ada pula yang beranggapan bahwa jualan mereka akan sepi dan tidak menguntungkan serta alasan kebersihan dimana pasar baru tersebut berhimpitan langsung dengan pemukiman masyarakat (Senin 30/03/2006 Kraton City PART II).

Hal ini membuat kebijakan ini berlarut-larut namun pemerintah tetap berupaya untuk meyakinkan padagang dan masyarakat setempat dengan melakukan berbagai pendekatan yang bersifat formal maupun non formal. Pendekatan formalnya dilakukan pemerintah dengan mengajak masyarakat setempat untuk berdiskusi secara langsung beberapa kali di Gedung Aulah Kantor Kecamatan Gondokusuman. Sementara pendekatan yang bersifat non formalnya dilakukan dengan cara mendatangi langsung tokoh-tokoh masyarakat setempat (Pendekatan Ketokohan), hal ini sangat efektif karena para tokoh tersebutlah yang akan meyakinkan masyarakat dan para pedagang terhadap kebijakan tersebut (Wawancara dengan Sekcam Godokusuman).

Salah satu alasan kebijakan ini berlarut-larut dilaksanakan juga karena pada tahun 2006 terjadi Gempa Bumi yang mengguncang Yogyakarta dan sekitarnya yang mengakibatkan semua fokus perhatian pemerintah tertuju pada penanganan korban gempa, inilah yang mengakibatkan kebijakan ini baru terealisasi pada tahun 2010 yang diresmikan oleh Walikota Herry Zudhianto pada Tanggal 25 April 2010 (Kedaulatan Rakyat, 26/04/2010). 
Ini cukup beralasan karena pada saat itu kondisi perekonomian masyarakat sangat lemah bahkan bisa dikatakan perekonomian Yogyakarta mengalami kelumpuhan, sehingga fokus perhatian pemerintah hanya tertuju pada korban bencana dan pemulihan sektor ekonomi. Pada tahun berikutnya barulah kebijakan ini mulai diperbincangkan kembali, setelah mendapat persetujuan dari masyarakat dan pedagang barulah proses pembangunan pasar itu dilaksanakan pada tahun 2009 .

Setelah gedung baru Pasar Talok diresmikan oleh Walikota Yogyakarta kemudian para pedagang diberi waktu selama lima hari untuk membereskan semua dagangan dan perabot yang lainya dari jalan Tridarma untuk ditempatkan pada pasar baru. Pada tanggal 1 Mei 2010 sebanyak 120 pedagang Pasar Talok resmi menempati pasar baru untuk melakukan aktifitasnya sebagaimana biasanya (Kedaulatan Rakyat, 02/05/2010). Pada awal peresmian pasar baru tersebut Pemerintah Kota

Yogyakarta lewat Dinas Pengelolaan Pasar memberikan kompensasi kepada para pedagang selama enam bulan sebagai masa uji coba untuk menempati pasar baru dengan membayar retribusi sama seperti dulu dan untuk pengelolaan parkirnya diserahkan kepada Pemuda atau Karang Taruna setempat untuk

mengelolanya. Setelah masa uji coba ini berakhir barulah pemerintah mengelola pasar tersebut dengan memberlakukan tarif retribusi pedagang sesuai dengan Perda No 03/2009 tentang Pasar.

b. Dinamika Sosial

Budaya kekerabatan dalam masyarakat jawa yang sangat terkenal dengan istilah tepa seliranya, dimana masyarakatnya saling membantu dan peduli satu sama lainnya. Sebagai makluk sosial para pedagang mempunyai ketergantungan antara satu dengan yang 
lainnya, dimana seseorang tak dapat hidup sendirian tetapi membutuhkan keberadaan orang lain, baik dalam keluarga maupun dalam kehidupan bermasyarakat. Hubungan ini sangat dipengaruhi oleh faktor hubungan kekerabatan yang berangkat dari realitas adanya hubungan komunalisme. Hal inilah yang membuat pertemanan diantara mereka sangat baik, toleransi mereka yang tinggi, solidaritas yang tinggi serta adanya pemakluman yang tinggi diantara mereka (A.R. Purnama Sari, 2004: 99).

Masih kuatnya ciri masyarakat pedesaan di kalangan pedagang Pasar Talok membawa aspek positif pada solidaritas kelompok. Jiwa gotong royong dan saling membantu diantara mereka masih kuat. Rasa keguyuban itu muncul masih dengan perasaan yang tulus pada diri mereka untuk membantu sesama dan oleh karena adanya perasaan hidup senasib dan sepenanggungan. Masih ada kewajiban pada diri mereka untuk menghadiri undangan baik itu perkawinaan, sunatan, slametan, atau acara hajatan yang lainnya. Untuk hal-hal yang bersifat sosial mereka tidak akan menghitung untung-ruginya dengan hilangnya kesempatan kerja, namun yang terpenting kehidupan sosial itu harus di kerjakan karena merekapun suatu ketika akan mengalami hal yang sama. 


\section{BAB III \\ AKTOR-AKTOR YANG TERLIBAT DALAM RELOKASI}

Setiap kebijakan biasanya selalu diusulkan oleh seseorang, kelompok, atau pemerintah dalam lingkungan tertentu. Penataan pedagang Pasar Talok Gendeng merupakan salah satu kebijakan yang dibuat oleh Pemerintah Kota Yogyakarta untuk memberikan perlindungan dan penguatan kepada para pedagang sekaligus wujud dari konsistensi pemerintah dalam merespon aspirasi masyarakat. Kebijakan ini diusulkan oleh berbagai pihak yang terlibat dalam proses perumusan kebijakannya.

Aspirasi masyarakat yang tertuang dalam Nota kesepakatan antara Pemerintah Kota dengan DPRD Kota tentang kebijakan umum APBD Kota Tahun Anggaran 2006 menyebutkan adanya perkembangan perekonomian dan dinamika masyarakat yang sangat berpengaruh pada adanya perbaikan dan pemeliharaan infrastruktur perkotaan yang berkesinambungan dan terintegrasi. Pembagunan gedung Pasar Talok merupakan salah satu usaha yang dilakukan dalam mewujudkan aspirasi tersebut.

Dengan merelokasi para pedagang pada bangunan yang disediakan oleh pemerintah tersebut, mengindikasikan adanya perhatian dari pemerintah dalam usaha penataan kota yang bersih sehat dan nyaman sekaligus sebagai upaya untuk meningkatkan pertumbuhan ekonomi yang bebasis kerakyatan sebagai perwujudan kebijakan umum dalam Nota Kesepahaman yang telah disepakati tersebut.

Melihat masing-masing peran aktor dan nilai serta kepentingan yang mereka perjuangkan, maka dapat diuraikan dan dijelaskan dalam sub bab berikut ini.

\section{A. Eksekutif (Wali Kota)}

Sangat menarik untuk mengetahui aktor yang terlibat dalam perumusan kebijakan relokasi pedagang Pasar Talok Gendeng Yogyakarta. Proyek pembangunan gedung baru (Pembangunan Fisik) yang seharusnya dibangun pada tahun 
2006 ketika kebijakan ini diwacanakan ternyata baru di bangun pada tahaun 2009. Sedangkan pembangunan non fisik untuk PKL mulai dilakukan dengan diisahkannya PERDA No 26 Tahun 2002 tentang penataan pedagang kaki lima yang ditindaklanjuti dengan SK Walikota untuk melaksanakan perda tersebut. Sementara kebijakan penataan PKL pada Pasar Talok dilakukan dengan dikeluarkannya Perwal Nomor 31/DPA/ SKPD/II/2007 tentang Penataan dan Pembagunan Gedung Pasar Talok. Dengan adanya regulasi tersebut maka pembangunan fisik Pasar Talok segera dilaksanakan.

Walikota Yogyakarta sebagai kepala daerah mempunyai tanggung jawab untuk memimpin Kota Yogyakarta agar terciptanya pelayanan yang prima kepada seluruh masyarakatnya tanpa kecuali. Peran strategis ini menuntut Walikota untuk dapat memenuhi tuntutan dan aspirasi warganya. Berkaitan dengan kasus relokasi pedagang Pasar Talok terlihat bahwa peran Walikota untuk mengarahkan kebijakan yang akan diambil cukup dominan.

Hasil wawancara dengan Ibu Sri Sumiyati (Ketua Paguyuban Pedagang Pasar Talok) memperoleh gambaran bagimana aktor yang terlibat dalam perumusan kebijakan relokasi, yang mengatakan bahwa

"Pelaksanaan kebijakan Pemerintah Kota dulunya selalu bersifat pemaksaan, karena ide awal selalu dari pemerintah dan jarang melibatkan masyarakat dalam merumuskan kebijakan yang dibuat. Ini sangat berbeda dengan Walikota sekarang (Herry Zuhdianto) dimana dalam membuat kebijakan diawali dengan wacana dan pendekatan-pendekatan dialog secara intesif dilaksanakan mulai dari menyusun konsep sampai perencanaan tata ruangnya. Penyususnan konsep ini mulai melibatkan masyarakat namun tidak mengasilkan apa-apa. Akhirnya pemerintah tidak melibatkan masyarakat lagi dalam proses perencanaan tersebut tetapi hanya mensosialisasikan hasil yang sudah dibuat kepada masyarakat". (Wawancara dengan Ibu Sri) 
Ternyata untuk membuat kebijakan yang melibatkan masyarakat pemerintah kurang sabar dengan berbagai permintaan yang beragam sehingga yang dilakukan adalah dengan melibatkan masyarakat dalam sosialisasi setelah kebijakan tersebut sudah diputuskan.

Dari hasil Feasibility Study yang dilakukan Bappeda Kota Yogyakarta diperoleh masukan bahwa tingkat pendidikan PKL cukup terdidik sehingga disarankan agar dalam proses pembuatan kebijakan, sebaiknya mengunakan pendekatan dialog dengan masyarakat atau mendatangkan para ahli/ pakar yang menguasai masalah sektor informal. Hal ini menjadi perhatian pemerintah karena dianggap sangat berpengaruh dalam menentukan keberhasilan dari proses kebijakan relokasi tersebut.

Tabel 2. Persentase Tingkat Pendidikan PKL

\begin{tabular}{|c|c|}
\hline Tingkat Pendidikan PKL & Persenstase (\%) \\
\hline Diploma & 4 \\
\hline SMA & 48,2 \\
\hline SMP & 22,7 \\
\hline SD & 25,1 \\
\hline
\end{tabular}

Sumber : Studi FS Pasar Talok 2007

Data tingkat pendidikan PKL akan mempengaruhi bagaimana kebijakan ini disosialisasikan dan dimplemen- tasikan. Tingkat pendidikan pedagang relatif tinggi sehingga memerlukan pendekatan dialogis dalam melakukan implementasi kebijakan tersebut. Latar belakang pendidikan mayoritas pedagang menjadi pertimbangan pemerintah kota dalam menyusun langkah-langkah relokasi yang akan ditempuh.

Kemudian diadakan jalinan komunikasi yang aktif antara Pemerintah Kota Yogyakarta dengan Pedagang Pasar Talok Gendeng, yang menurut Ibu Sri : 
"Kalau di istilahkan, komunikasi yang terjalin dengan paguyuban pedagang Pasar Talok seperti pembicaraan orang tua dengan $\mathrm{ABG}$ yang memang sulit diajak komunikasi karena mereka mempunyai pandangan yang berbeda. Proses penyamaan pandangan ini dilakukan secara intensif sehingga persepsi yang dibangun mempunyai persamaan untuk menciptakan Yogyakarta Berhati Nyaman bagi seluruh warga. Komunikasi ini dilakukan dengan mengungkapkan realitas dan bagaimana penataan yang seharusnya dilakukan kepada kami selaku Pedagang" (Wawancara dengan Ibu Sri).

Dialog yang sudah berjalan baik tersebut terancam gagal dalam perumusan masalahnya karena adanya penolakan dari masyarakat sekitar terhadap rencana relokasi tersebut dengan alasan kalau direlokasi ke pemukiman warga akan mengganggu ketertiban dan kebersihan lingkungan tersebut. Ada pula beberapa pedagang yang beralasan kalau direlokasi tentunya pendapatan mereka akan berkurang tidak seperti pada tempat sebelumnya.

Dengan berbagai alasan inilah yang membuat implementasi dari kebijakan ini memerlukan waktu yang cukup lama. Namun pemerintah tidak tinggal diam proses dialog dan sosialisasi terus dilaksanakan. Dalam proses pendekatan ini pihak kecamatan mempunyai peranan yang sangat penting dalam melaksanakan amanat yang telah dipercayakan dari atas. Seperti yang dikatakan oleh Sekretaris Camat (Sekcam) Gondokusuman Bpk. Agus Arif Nugroho bahwa :

"Pihak kecamatan tidak tinggal diam, kami terus berupaya untuk melakukan pendekatan dengan pedagang dan masyarakat sekitar dengan melakukan sosialisasi, dialog bahkan sampai dengan pendekatan Door to door dengan tokoh-tokoh masyarakat setempat, seperti Ketua RT, RW, Tokoh Agama, dam Karang Taruna. Lewat berbagai upaya yang dilakukan tersebut akhirnya kebijakan ini dapat dipahami sehingga tidak terjadi konflik seprti yang terjadi pada daerah-daerah yang lain" (Wawancara dengan Sekcam). 
Setelah mendapatkan gambaran awal tentang kesediaan dari pedagang untuk direlokasi maka kebijakan tersebut harus mendapatkan dukungan dari Legislatif. Karena bila Legislatif tidak mendukung kebijakan ini maka anggaran untuk program pembangunan gedung fisiknya tidak akan disetujui. Hal ini sesuai hasil wawancara dengan Bapak Baskoro selaku Kabid Ekonomi dan Pembangunan Bappeda Kota Yogyakarta.

"Langkah berikutnya adalah meyakinkan pihak legislatif bahwa kebijakan ini dimaksudkan untuk mengangkat harkat dan martabat para pedagang dengan merelokasi mereka secara gratis dari jalan Tridarma. Selain itu untuk menghindari kemacetan pada waktu pagi hari sekaligus untuk menyediakan tempat yang nyaman bagi para pedagang untuk berjualan, kemudian penyusunan tahapan relokasi dibuat agar anggaran berjalan sesuai dengan rencana" (Wawancara dengan Baskoro).

Hal di atas senada dengan apa yang disarankan dalam studi kelayakan yang dilakukan tentang kemampuan penghasilan PKL yang sangat terbatas. Kemampuan penghasilan PKL juga menjadi pertimbangan dalam penjualan lapak di lokasi yang baru. Untuk itu pengambil kebijakan harus dapat meyakinkan anggota Dewan agar pedagang Pasar Talok dapat ditempatkan pada pasar yang baru tanpa dipungut biaya pembangunan fisik.

Pemberian lapak secara gratis kepada para pedagang merupakan langkah antisipatif agar mereka tidak menolak untuk direlokasi. Bila mereka diwajibkan untuk membeli dasaran tempat berjualan maka mereka akan keberatan karena keterbatasan modal dan penghasilan yang dimiliki.

Seiring dengan itu perkembangan Pasar Talok semakin ramai dan menimbulkan masalah ketidak-nyamanan bagi penduduk setempat terutama permasalahan ketertiban dan akses atau mobilitas masyarakat terhadap jalan Tridama yang mengalami kelumpuhan dan kemacetan pada waktu pagi hari hingga siang hari. Dalam acara Selamat Pagi Yogyakarta Walikota Menyapa, banyak masukan dari pemerhati kota tentang kemacetan dan kesemrawutan pada jalan tersebut. 
Demikian juga dari Unit Pelayanan Informasi Kota (UPIK) melalui SMS (short massege sender) yang masuk, menuntut agar Pemkot segera untuk menata Pasar Talok di jalan Tridarma sehingga tidak terkesan kumuh dan tidak teratur.

Ide pertama kali relokasi pedagang Pasar Talok di jalan Tridarma berasal dari ide Walikota yang mendapat desakan dari berbagai pihak terutama dari masyarakat sekitar yang merasa tidak aman dan nyaman pada waktu melewati jalan tersebut. Pejalan kaki juga merasa haknya terenggut dengan keberadaan aktivitas pasar tersebut. Hal tersebut senada dengan apa yang diungkapkan oleh Bapak Baskoro bahwa :

"Kebijakan ini sesuai dengan harapan dan keinginan masyarakat sekitar untuk melakukan penataan pada Jalan Tridarma agar tidak terjadi kemacetan sekaligus memberikan kenyamanan kepada pembeli dan pedagang dari hujan dan panas, sehingga dengan memberikan tempat yang permanen bagi pedagang merupakan salah satu solusi dari persoalan dan permasalahan tersebut. Ide yang dicetuskan oleh Walikota tersebut kemudian Bappeda menyusun kelengkapan dokumen yang menjadi syarat sebuah perencanaan kebijakan fisik relokasi. Kebetulan pada area sebelah selatan Jalan Tridarma di kampung Gendeng terdapat lokasi/tanah milik Pemerintah Kota yang masih kosong dan belum termanfaatkan sehingga Pemkot tidak kerepotan dalam pembangunan fisik gedung pasar tersebut" (Wawancara dengan Baskoro).

Tentu saja Walikota tidak melaksanakan sendirian apa yang menjadi kebijakan Pemerintah Kota Yogyakarta. Bappeda sebagai lembaga yang bertanggung jawab untuk memikirkan bagaimana kelengkapan suatu kebijakan agar kebijakan tersebut mendapatkan legitimasi dan persetujuan dari legisaltif. Pada akhirnya kebijakan Relokasi Pedagang Pasar Talok ini dapat dilaksanakan karena telah mendapat anggaran yang disetujui oleh anggota Dewan Kota Yogyakarta. 


\section{B. Badan Perencanaan dan Pembangunan Daerah (Bappeda)}

Aktor utama yang menerjemahkan perintah Walikota biasanya Bappeda Kota. Pada prinsipnya setiap kebijakan Kota Yogyakarta akan melalui Bappeda, kemudian akan disiapkan dokumen perencanaan untuk setiap kebijakan yang akan diambil. Pada proses ini maka penyusunan studi kelayakan selalu menjadi urutan pertama terhadap usulan kebijakan yang akan dilaksanakan.

Persiapan dokumen pertama yang dilakukan adalah melakukan kajian lokasi oleh Dinas Lingkungan Hidup baru kemudian muncul FS Rancang Bangun Aset Daerah oleh Bappeda pada tahun 2007. Pada tahun berikutnya dibuat Detail Engineering Design (DED) dan pelaksanaan bangunan fisik oleh Badan Pengelolaan Barang dan Aset Daerah. Terlihat di sini peran Bappeda dalam menyiapkan urutan kebijakan sudah sesuai dengan alur aturan hukum yang berlaku sehingga nantinya dapat diterima oleh legislatif.

Dalam perumusan kebijakan tidak luput dari pengaruh proses otonomi daerah yang memberikan keleluasaan kepada pemerintah daerah untuk menentukan kebijakan sesuai dengan kondisi, tuntutan dan potensi yang dimiliki oleh masing- masing daerah. Inovasi dan tuntutan kebutuhan yang mendadak dapat muncul karena ada persoalan yang harus diatasi. Keadaan perkembangan perkotaan dan perkembangan jumlah pedagang Pasar Talok serta adanya keinginan untuk memajukan perekonomian yang berpihak pada rakyat kecil menjadi latar belakang dari perumusan kebijakan relokasi Pasar Talok tersebut.

Menurut Bapak Baskoro selaku Kabid Ekonomi dan Pembanguan Bappeda Kota Yogyakarta yang mengatakan bahwa :

"Pada prinsipnya proses penyiapan dokumen perencanaan dilakukan dengan target efektifitas ekonomi. Proses penyiapan dokumen akan digeneralisir dan dimodifikasi sedikit, kemudian dilakukan studi kelayakan terhadap keberadaan pasar tersebut" 
Saat ini Walikota sangat konsisten dengan pemberdayaan masyarakat miskin (wong cilik). Prioritasnya adalah membangun Kota Yogyakarta agar maju sehingga secara otomatis akan mengurangi orang miskin dengan sendirinya. Hal ini biasa dilihat dari berbagai kebijakan yang dibuat untuk menguatkan masyarakat kecil terutama para pedagang ekonomi lemah. Salah satu kebijakan yang di anggap berhasil adalah melakukan relokasi terhadap PKL di jalan Mangkubumi ke Pasar Klithikan yang pelaksanaannya berjalan dengan lancar.

Tentang cara kerja Bappeda dalam menyiapkan perencanaan setiap kebijakan harus sesuai dengan kondisi dan situasi yang terjadi. Seperti yang dikemukakan oleh Bapak Baskoro berikut ini.

"Yang jelas pada saat ini program-program yang dilakukan Bapedda kebanyakan sebagai jaringan pengaman kemiskinan. Apabila Bappeda mempunyai inisiatif untuk mengembangkan wilayah tertentu, akan dilakukan studi kelayakan yang kadang memunculkan saran diluar yang direncanakan. Contoh pasar Terban yang direncanakan sebagai pusat onderdil untuk Yogyakarta wilayah utara yang juga akan melayani masyarakat Sleman. Tetapi hasil dari studi kelayakan menyarankan alternatif lain karena lingkungan di sekitar pasar Terban adalah sekolah. Hal ini menjadi pertimbangan agar jangan sampai setelah dilakukan ternyata yang apa yang diharapkan tidak terjadi"

Melihat kenyataan sebelumnya maka Bappeda harus mempertimbangkan segala kemungkin sebelum proses penyiapan dokumen dari kebijakan tersebut dilakukan. Hal ini sesuai dengan yang dikatakan oleh Bapak Daryanto selaku Kabid Fisik Bappeda bahwa :

"Selaku kepala bidang fisik saya tidak mau menerima kebijakan Relokasi Pedagang Klithikan waktu itu sebelum semua kelengkapan dokumen yang menjadi syarat sudah ada. Sama halnya dengan relokasi Pasar Talok semuanya harus lengkap sehingga dapat dibuat penetapan anggarannya untuk mengejar kekurangan 2 
(dua) dokumen dengan instansi Badan Pengelolaan Barang Daerah (BPBD) dan Badan Pengelolaan Keuangan Daerah (BPKD) pada awal tahun anggaran dengan anggaran murni yang disusun oleh FS Rancang Bangun Aset Daerah"

Jadi dari hasil wawancara di atas dapat diperoleh keterangan bahwa proses perencanaan kebijakan Relokasi Pasar Talok merupakan proses ekonomis yang dinamis dengan memanfaatkan dokumen yang sudah ada, barulah dilengkapi dengan apa yang seharusnya menjadi syarat suatu kelengkapan kebijakan.

\section{Dinas Perindustrian, Perdagangan dan Koperasi (Disperindakop)}

Aktor lain yang terlibat dalam perumusan kebijakan ini adalah Dinas Perindustrian, Perdagangan dan Koperasi (Disperindakop) Kota Yogyakarta sebagai leading sektor yang mempunyai tugas pokok dan fungsi membina pedagang kaki lima, melakukan inventarisasi ketugasan kemudian disusun menjadi sebuah dokumen yang akan dipakai sebagai bahan referensi untuk membuat kebijakan.

Pengalaman berbagai relokasi yang pernah sukses dilaksanakan oleh suatu instansi, telah menjadikan aktor yang terlibat diminta kembali untuk mengulangi kesuksesannya pada instansi lain. Bapak Sukirno dulu selaku Kepala Dinas Sosial telah berhasil melaksanakan relokasi Sanggrahan yang merupakan Lokasi WTS. Beliau kemudian di tugaskan ke Disperindakop untuk menangani pedagang kaki lima. Bukti yang dilakukannya adalah Berhasilnya relokasi pedagang pasar Klithikan tanpa gejolak (Dwi A. Hardiyanti, 2008: 71).

Dari hasil wawancara yang dilakukan dengan Bapak Sukirno di kantornya menuturkan bahwa :

"Proses penutupan lokalisasi WTS Sanggarahan oleh Dinas Sosial pada tahun 1998 telah mengawali Pemerintah Kota Yogyakarta dalam kebijakan relokasi- relokasi yang lain. Penutupan ini kemudian menjadi contoh bagi daerah lain karena berhasil tanpa gejolak. 
Sama halnya dengan keberhasilan kebijakan relokasi Pasar Klithikan tanpa gejolak, ini tidak lepas dari kesabaran kita dalam melakukan berbagai pendekatan yang lunak sehingga kebijakan tersebut dapat dipahami maksudnya"

Dari proses-proses inilah yang membuat adanya kepercayaan dari masyarakat kepada pemerintah dalam menata Pedagang Kaki Lima di kawasan Kota Yogyakarta. Keberhasilan relokasi pedagang Klithikan tidak lepas dari peran Bapak Sukirno Selaku Kepala instansi yang menangani PKL tersebut.

Pada dasarnya keberadaan pedagang kaki lima merupakan realitas dari perekonomian kota dan hal ini telah menjadi sorotan tajam masyarakat yang merasa haknya sebagai pejalan kaki telah di rampas. Realitas ini tidak dapat dipungkiri sehingga perlu kesabaran, ketelitian di dalam melakukan berbagai kebijakan yang bersentuhan langsung dengan kehidupan mereka. Dengan pemahaman seperti inilah yang melatarbelakangi berbagai kesuksesan dan keberhasilan dari Pemerintah Kota dalam berbagai kebijakan relokasi yang dilakukan. Semua kebijakan itu berhasil dilakukan karena peranan dari aktor-aktor yang diberi kewenangan.

\section{Dinas Pengelolaan Pasar (Dinlopas)}

Dinas Pengelolaan Pasar (Dinlopas) adalah Dinas yang akan menangani pedagang paska relokasi. Dinlopas diberi tugas untuk mencari data terkait dengan pedagang di Pasar Talok yang akan ditata, sehingga dinas ini dilibatkan sejak awal agar memahami kondisi pedagang yang akan ditata. Dengan metode informan yang disebar di lokasi, maka informasi tentang pedagang dapat diketahui untuk menyusun langkah- langkah dialog atau persiapan sosialisasi.

Hal ini sesuai dengan yang di ungkapkan oleh Bapak Totok Sudiarto selaku Kepala Seksi Pengembangan Pasar bahwa : 
"Sebelum rapat-rapat yang bersifat formal untuk sosioalisasi kebijakan dilakukan, Dinas Pengelolaan Pasar menyebar stafnya untuk mencari informasi perkembangan dan apa yang kira-kira akan menjadi tuntutan pedagang. Kemudian secara internal akan diadakan rapat formal untuk mengantisipasi keadaan sebelum dilakukan rapat dengan komunitas" (hasil wawancara dengan Bapak Totok)

Peranan yang penting ini dikoordinir oleh Kepala Dinas dalam merumuskan kebijakan dengan cara melakukan dialog non formal secara intensif dengan pedagang sesuai dengan situasi dan kondisi yang dibutuhkan. Pendekatan yang manusiawi dilakukan untuk dapat menangkap keinginan dari para pedagang. Pada akhirnya pedagang memahami maksud dari kebijakan tersebut dan setuju untuk direlokasi.

Tekait dengan tahapan-tahapan yang dilakukan oleh Dinas pengelolaan Pasar sebelum melakukan relokasi terhadap para pedagang, maka hasil Wawancara yang dengan Ir. Bernadeta Tuti Budyarsih selaku Kepala Seksi Penataan Lahan Dinas Pengelolaan Pasar yang menuturkan bahwa :

"Langkah pertama yang dilakukan adalah melakukan pendataan kepada para pedagang di pasar lama yang meliputi data keleluasaan lahan dasaran, jenis dagangan, jam buka dan identitas pedagang. Kemudian dikoordinasikan dengan Dinasdinas yang terkait untuk memaparkan wacana atau mensosialisasikan kepada masyarakat dan pedagang, setelah disetujui barulah proses relokasi itu dilaksanakan"

Dari hasil wawancara tersebut dapat dikatakan bahwa peranan yang dilakukan oleh Dinlopas sangat penting sehingga perencanaannya dilakukan dengan baik yang membuat para pedagang dapat memahami maksud dari kebijakan relokasi ini. Keseriusan dari Dinlopas dalam melaksanakan kebijakan ini terlihat dari apa yang dilakukan mulai pendataan sampai pada sosialisasi kepada masyarakat. Semuanya dilakukan secara 
intens sehingga menjadikan kebijakan ini berjalan dengan lancar tanpa gejolak.

\section{E. Legislatif (DPRD)}

Legislatif adalah salah satu lembaga yang berfungsi sebagai tempat penyaluran aspirasi masyarakat atau sebagai lembaga tempat pengaduan masyarakat terhadap berbagai kebijakan yang tidak berpihak pada masyarakat. Dalam hal kebijakan relokasi Pasar Talok pada prinsipnya para anggota legislatif dapat memahami kekuatiran masyarakat dan para pedagang yang belum memahami konsep kebijakan yang di tawarkan oleh pemerintah tersebut. Semua kelompok yang menyalurkan aspirasinya harus ditanggapi secara seimbang oleh anggota legislatif terutama Komisi B yang membidangi perekonomian.

Ide utama kebijakan relokasi Pasar Talok berasal dari Eksekutif dan Dewan sebagai mitra kerjanya diajak untuk membahasnya, setelah disetujui barulah proses pembahasan anggaran dilakukan. Dalam pembahasannya Dewan memberi masukan kepada Eksekutif agar kebijakan ini dilaksanakan tanpa ada konflik atau gejolak dan sebisa mungkin diselesaikan dengan berdialog.

Peran anggota Dewan dalam kebijakan relokasi pedagang Pasar Talok diakui Bapak Zulnasri salah satu anggota Dewan dari Komisi B bahwa :

"Konsep kebijakan relokasi ini berasal dari eksekutif yang dalam proses pembahasannya Dewan dilibatkan sampai dengan terealisasinya kebijakan tersebut. Konsep kebijakan ini relatif memadai dengan berbagai kepentingan baik dari para pedagang maupun dari masyarakat dan pemerintah. Namun kita harus melihat bahwa keberadaan pasar tersebut cukup mengganggu aktifitas masyarakat terutama menyankut kemacetan pada jalan tersebut sehingga kita akan memberikan kawalan terhadap kebijakan ini. Apabila ada masyarakat yang tidak menyetujui kebijakan ini maka kita akan berusaha untuk menyalurkan aspirasi mereka" (Wawancara dengan Bapak Sinar). 
Hal yang senada juga disampaikan oleh Bapak Zurif Hudaya selaku Ketua Komisi C DPRD Kota Yogyakarta terkait dengan ide awal relokasi tersebut sebagai berikut :

"Sesungguhnya yang mempunyai ide relokasi adalah eksekutif yang kemudian dibahas dengan legislatif. Karena prosedur yang diajukan oleh eksekutif sudah sesuai dengan prosedur yang berlaku seperti sudah melalui penyusunan Feasibility study (FS), kemudian Penyusunan Detail Engineering design (DED) dan di tenderkan sesuai dengan prosesnya berdasarkan peraturan yang berlaku dan tidak ada penyelewengan maupun penyimpangan, maka kami yang membawahi pembangunan dan pengawasan fisik dapat menyetujui dan mendukung kebijakan relokasi tersebut. Komisi C akan mengawal pelaksanaan pembangunan fisik dengan pantauan yang ketat terhadap kebijakan itu sampai selesai pembangunannya hingga kebijakan ini dapat diimplementasikan"

Dengan demikian jelaslah bahwa konsep kebijakan relokasi ini berasal dari pihak eksekutif dan pihak legislatif hanya memberikan pengawalan dan pengawasan terhadap kebijakan tersebut karena sudah menjadi tuntutan publik. Apabila kebijakan ini tidak dilakukan maka pasar tersebut akan semakin ramai sehingga tidak dapat terkendali lagi. Sepatutnya harus dibuat bangunan permanen untuk mewadahi para pedagang tersebut agar mereka tidak lagi menggunakan jalan Tridarma sebagai tempat untuk berjualan.

\section{F. Kecamatan Gondokusuman}

Salah satu aktor yang mempunyai peranan penting dalam mewujudkan keberhasilan dari kebijakan ini adalah Kecamatan Gondokusuman yang merupakan kepala wilayah dari keberadaan Pasar Talok tersebut. Peranan yang penting ini tidak lepas dari keberadaan kecamatan sebagai salah satu unsur dari pemerintah yang harus melaksanakan segala keputusan yang telah di putuskan di tingkat atas. Ketika wacana kebijakan relokasi ini digulirkan maka respon dari 
masyarakat pun sangat beragam ada yang pro terhadap kebijakan tersebut namun ada pula yang menolak kebijakan tersebut.

Terhadap mereka yang menolak kebijakan ini pihak kecamatan terus melakukan berbagai upaya pendekatan yang lunak dengan mereka. Hal ini terlihat dari pernyataan Camat Gondokusuman, Bapak Ari Sudaryanto yang mengatakan bahwa :

"Pedagang Pasar Talok tetap menolak untuk direlokasi, mereka tetap memilih untuk berjualan di jalan Tridarma pinggir jalan lintasan jalur kereta api Kampung Gendeng. Namun kami tetap melakukan sosialisasi terus menerus karena 'Tugas kami hanya sebagai jembatan komunikasi antara Pemkot dan warga sekitar, untuk menentukan langkah berikutnya kami menunggu jawaban dari Pemkot karena kami sudah melaporkan hasil sosialisasi tersebut kepada Sekda melalui Badan Pengelola Barang Daerah (BPBD) Kota Jogja'. Penolakan terhadap kebijakan ini disebabkan karena permasalahan limbah yang di hasilkan pasar dikuatirkan akan menggangu lingkungan dari wilayah tersebut" (Jogja, 03/03/2006 Kraton City PART II)

Ini menunjukan bahwa peranan kecamatan dalam menterjemakan keputusan dari Pemerintah Kota sangat penting, berbagai upaya dialog dan sosialisasi terus dilakukan agar kebijakan ini dapat dipahami dan disetujui oleh para pedagang dan masyarakat sekitar yang tetap menolak untuk direlokasi. Lebih lanjut Sekretaris Kecamatan Gondokusuman, Bapak Agus Arif Nugroho menambahkan bahwa :

"Adanya pro dan kontra dari warga terhadap pembangunan pasar ini sudah muncul tahun sejak tahun 2006. Bahkan, saat itu gagasan relokasi berasal dari pedagang Pasar Talok itu sendiri. Meskipun akhirnya sempat terhenti karena adanya gempa yang cukup hebat dan melanda Yogyakarta. Kami tetap melakukan berbagai upaya sosialisasi bahkan melakukan upaya- upaya pendekatan yang bersifat ketokohan lintas wilayah dengan mendatangi para tokoh-tokoh 
masyarakat dan agama serta pemuda karang taruna untuk memberikan penjelasan kepada masyarakat agar mereka dapat mengerti dan memahami maksud dari kebijakan ini”

Dengan demikian keberhasilan dari pelaksanaan kebijakan ini tidak terlepas dari berbagai upaya yang dilakukan oleh pihak kecamatan, baik itu secara langsung maupun tidak langsung. Ini tidak lepas dari keberadaan kecamatan yang lebih mengetahui maksud serta kondisi dari masyarakat tersebut sehingga langkah-langkah dan berbagai upaya yang dilakukan dapat disesuaikan dengan kondisi dan situasi masyarakat tersebut. Peranan komunitas dan paguyuban pedagang Pasar Talok serta organisasi kemasyarakatan pun sangat penting dalam mewujudkan keberhasilan pelaksanaan kebijakan ini. Paguyuban Pedagang Pasar Talok sebagai salah satu komunitas dari pedagang secara tidak langsung terlibat dalam proses kebijakan ini karena banyak dilibatkan dalam membicarakan wacana serta aspirasi yang berhubungan langsung dengan kebijakan ini.

LSM IMPLAW (Indonseia Monitoring Prosedure of Law) yang merupakan salah satu Lembaga Swadaya Masyarakat yang sudah banyak terlibat dalam proses-proses relokasi di Kota Yogyakarta mempunyai peranan yang cukup penting dalam memberikan perhatian dan penguatan kepada masyarakat sekitar terutama para pedagang dengan kasus relokasi yang sama. Upaya pendampingan yang dilakukan tersebut sangat membantu dalam memberikan masukanmasukan yang penting kepada pemerintah untuk diadopsi dalam pembuatan kebijakan. Ini pun yang dilakukan terhadap pedagang pada Pasar Talok dengan selalu memperhatikan wacana yang berkembang di masyarakat untuk disampaikan kepada pemerintah.

Berikut ini akan di gambarkan berbagai faktor dan situsi yang mendukung atau mendesak untuk segera melakukan penataan terhadap keberadaan Pasar Talok seperti yang terlihat pada bagan berikut ini : 


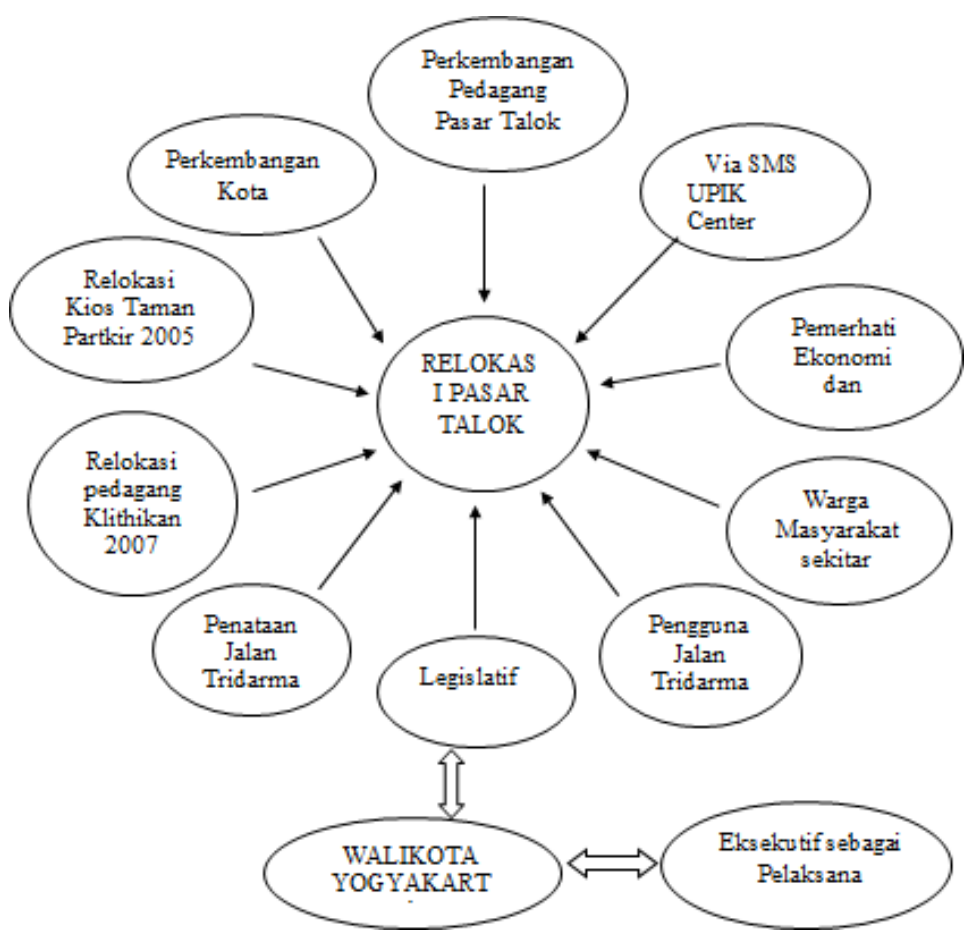

Gambar 2. Isu yang Mendesak untuk Relokasi

Dari hasil analisa terhadap kebijakan ini terlihat terdapat banyak aktor yang terlibat dalam proses perumusan masalahnya. Walikota sebagai pencetus ide yang didesak oleh berbagai kelompok kepentingan seperti Pemerhati Ekonomi Kota, Komunitas Penduduk di wilayah sekitar Pasar Talok, perkembangan kota dan desakan dari legislatif. Kemudian hal ini diterjemahkan oleh Bappeda dan dilaksanakan oleh Dinas Perindustrian, Perdagangan dan Koperesi serta dibantu oleh Dinas Pengelolaan Pasar dan Kecamatan.

Peranan stake holders seperti LSM IMPLAW dalam melakukan penguatan terhadap masyarakat dan para pedagang dalam proses perumusan kebijakan relokasi ini sangat penting dalam mewujudkan keberhasilan dari pelaksaan kebijakan tersebut. Peran legislatif yang bisa menerima 
kebijakan tersebut karena sudah sesuai dengan prosedur yang berlaku seperti adanya feasibility study, adanya Rancangan Bangunan Fisik, DED dan Pelaksanaan Fisik lewat mekanisme tender yang tidak ada penyelewengan sehingga kebijakan ini sangat rasional untuk melakukan penguatan terhadap sektor informal.

Dengan melakukan identifikasi terhadap aktor-aktor yang terlibat dalam kebijakan ini serta berbagai peranan dan kepentingannya dalam kebijakan ini seperti yang telah dibahas sebelumnya maka selanjutnya penulis akan membahas bagaimana proses perumusan kebijakan relokasi pedagang Pasar Talok ini pada bab selanjutnya. 


\section{BAB V \\ PROSES PERUMUSAN KEBIJAKAN RELOKASI PASAR}

Pada bagian ini akan membahas proses perumusan kebijakan relokasi Pasar Talok yang terletak di jalan Tridarma Gendeng, Kelurahan Baciro, Kecamatan Gondokusuman Kota Yogyakarta. Untuk uraian lebih jelasnya akan dibagi dalam beberapa sub bab yang dimulai dengan menganalisa permasalahan yang dihadapi, penyususnan Perda Kota Yogyakarta tentang PKL yang menjadi payung hukum kebijakan, melihat pendekatan yang digunakan dengan berbagai pengalaman relokasi dan alternatif kebijakan serta peran-peran aktor yang terlibat dalam proses perumusan masalah kebijakan relokasi Pasar Talok.

\section{A. Permasalahan}

Perumusan kebijakan yang sering menjadi acuan adalah "problrm oriented" yaitu berusaha untuk menyelesaikan apa yang dianggap menjadi masalah. Untuk itu menemukan apa yang menjadi inti dari permasalahan adalah hal yang penting dalam perumusan masalah. Kalau penulis berusaha untuk memetakan masalahnya adalah sebagai berikut :

Tabel 3 . Permasalahan yang Dihadapi

\begin{tabular}{|l|l|l|}
\hline No & \multicolumn{1}{|c|}{ Masalah } & \multicolumn{1}{|c|}{ Aksi } \\
\hline 1. & Umum & $\begin{array}{l}\text { Relokasi Pedagang Pasar Talok } \\
\text { Gendeng }\end{array}$ \\
\hline 2. & Rincian & $\begin{array}{l}\text { Perkembangan Kota Yogyakarta Penataan } \\
\text { Jalan Tridarma } \\
\text { Keberadaan Pasar yang menyebakan } \\
\text { kemacetan } \\
\text { Kebersihan dan Ketertiban }\end{array}$ \\
\hline 3. & Strategi/Inti & Penguatan sektor informal \\
\hline
\end{tabular}


Proses perumusan kebijakan relokasi pedagang Pasar Talok merupakan serangkaian kegiatan dan peristiwa yang sering terkait sehubungan dengan perkembangan Kota Yogyakarta. Tuntutan masyarakat untuk melakukan penataan terhadap keberadaan pasar tersebut dimaksudkan untuk mengembalikan fungsi jalan Tridarma sebagaimana yang diharapkan sekaligus untuk meminimalisir perkembagan pasar yang semakin meningkat sehingga dikuatirkan akan sulit direlokasi jika para pedagangnya sudah bertambah banyak.

Perkembangan Kota Yogyakarta tidak dapat dilepaskan dari persoalan Rencana Tata Ruang Wilayah Yogyakarta sebagaimana hasil wawancara dengan Ir. Sudarsono, selaku Kepala Bidang Tata Ruang Dinas Kimpraswil Kota Yogyakarta menuturkan :

"Pertimbangan Walikota terhadap keberadaan Pasar Talok yang cukup mengganggu pengguna jalan Tridarma sangat tidak sesuai dengan perkembangan dan kemajuan kota serta sangat mengganggu kesehatan lingkungan di sekitar pasar tersebut. Hal lain yang menunjang adalah tata ruang kota yang bersifat fleksibel. Artinya Pemerintah Kota tidak mau Rencana Tata Ruang Kota dan Wilayah diatur secara kaku. Hal ini disebabkan perkemabangan kota yang sangat dinamis dan perlu wadah agar perkembangan tersebut nantinya sesuai dengan keadaan dan kondisi yang ada"

Sejalan dengan itu muncul pemikiran bahwa keberadaan pasar tersebut sudah tidak sesuai lagi dengan perkembangan kota sehingga harus direlokasi selain untuk memberikan kenyamanan kepada pengguna jalan, juga melakukan penguatan terhadap sektor informal. Harapannya ketika para pedagang sudah menempati pasar yang baru maka ekonomi mereka semakin bertambah dengan semakin ramainya pembeli pada pasar baru tersebut. kebijakan ini juga dimaksudkan untuk memberikan kenyamanan tempat berjualan bagi para pedagang dan tidak mengganggu yang lain. 
Berkaitan dengan keberadaan pasar tersebut yang cukup mengganggu masyarakat sekitar, maka di ungkapkan oleh salah seorang warga ketika diwawancarai yang mengatakan bahwa :

"Realitas yang ada perkembangan pedagang dan Pasar Talok sudah membuat tidak nyaman pengguna jalan dimana pada waktu pagi hari jalan tersebut sangat ramai dan tidak dapat di lewati (macet total) serta adanya sampah yang berserakan dimana-dimana yang sangat mengganggu kesehatan lingkungan masyarakat terutama kami yang rumahnya berhadapan langsung dengan keberadaan Pasar tersebut, sehingga saya sangat mendukung kebijakan relokasi ini untuk menempatkan pedagang pada satu bangunan sehingga sampah dan kebersihan lingkungan tetap terjaga" (wawancara dengan Ibu Atun)

Dengan demikian dapat disimpulkan bahwa permasalahan utama pemindahan pedagang pasar Talok merupakan serangkaian peristiwa yang berawal dari tuntutan masyarakat dan warga sekitar untuk memfungsikan jalan Tridarma dari kemacetan sekaligus memberikan kenyamanan pada para pedagang dan masyarakat sekitar karena keberadaan pasar tersebut cukup mengganggu terutama yang berkaitan dengan kebersihan dan ketertiban.

\section{B. Penyusunan PERDA 26/ 2002}

Berbagai kebijakan yang berkaitan dengan relokasi merupakan perjalanan panjang upaya-upaya dialog-dialog yang dilakukan Pemerintah Kota dengan para komunitas Pedagang Kaki Lima. Walikota Syukri Fadholi mengadakan inspeksi mendadak kesejumlah lokasi PKL dan mengadakan dialog langsung. Pemerintah akan menindak tegas keberadaan PKL enam bulan ke depan, karena telah dilaksanakan sosialisasi, pembinaan, dan penataan terkait dengan pelaksanaan PERDA 26/2002 (Bernas, 25 Juli 2003) 
Menurut Bapak Benny sebagai Kepala Seksi Perdagangn di Dinas Perdagangan dan Perindustrian Kota menuturkan bahwa :

Kebijakan penataan PKL merupakan win-win solution antara mengakomodir kepentingan pedagang dan memberikan hak pada penguna jalan sekaligus memfungsikan trotoir sebagaimana tertuang dalam UU No 14/1992 yang menyebutkan fungsi utama trotoir adalah untuk pejalan kaki. Hal ini dapat diartikan bahwa trotoir dapat difungsikan untuk hal lain seperti pemberdayaan ekonomi kerakyatan untuk PKL dengan dibatasi koridor-koridor tertentu. Koridor tersebut adalah regulasi seperti PERDA 26/2002 dan petujuk pelaksanaannya sampai dengan PERWAL 45/2007. Adanya SK Camat yang mengatur titik-titik trotoir yang diperbolehkan untuk dimanfaatkan oleh PKL dengan metoda zero growt yaitu tidak memberi ijin tambahan bagi PKL baru merupakan koridor baru dimaksud"

Pelaksanaan penataan PKL dimulai dengan dibuatnya PERDA 26/2002 yang telah disahkan oleh DPRD Kota dan ditindaklanjuti dengan Surat Keputusan Walikota untuk pelaksanaan PERDA tersebut.

"Dalam Proses pembuatan aturan hukum ini, pedagang disentuh tentang keberadaan mereka. Posisi mereka yang ratarata sebagai pedagang kecil yang mencari nafkah dalam memenuhi kebutuhan hidupnya. Pemerintah Kota berfungsi untuk mengatur dan membuat regulasi yang berkewajiban melindungi seluruh warga di Kota Yogyakarta dan menata lingkungan Kota sehingga tercipta lingkungan yang nyaman, aman, tertib dan bersih sebagaimana dengan slogan Pemerintah Kota YOGYAKARTA BERHATI NYAMAN" (Wawancara dengan Bapak Sukirno).

Berbagai dialog dilaksanakan baik yang bersifat formal maupun yang besifat nonformal disesuaikan dengan kondisi dan situasi yang dialami oleh masyarakat maupun pedagang. Proses dialog berlangsung baik di kantor kecamatan maupun di areal sekitar pedagang setelah proses jual beli berakhir. Setelah 
kesadaran akan posisi mereka tergugah dan terbentuk, mereka diajak berdialog untuk membuat aturan mereka sendiri yang terbaik seperti apa. Ketika mereka diminta untuk membuat aturan yang sesuai dengan keinginan mereka, mereka meminta draf yang di buat oleh Pemerintah Kota karena mereka merasa tidak mampu. Akhirnya proses dialog dilaksanakan dengan membahas draf yang dibuat oleh pemerintah.

Lebih lanjut Bapak Sukirno mengatakan bahwa :

"proses pembuatan aturan hukum ini bermula dari rancangan Perda 26/2002 yang masih belum menyentuh kawasankawasan tempat PKL berada seperti, jalan Mangkubumi, termasuk Malioboro. Inilah yang mendorong lahirnya Perda tersebut untuk melakuan penataan terhadap PKL yang pada akhirnya bisa dilaksanakan. Contohnya relokasi pedagang Klithikan dari jalan mangkubumi yang berhasil dilaksanakan” (Wawancara dengan Bapak Sukirno).

Keterlibatan dari objek kebijakan dalam perumusan kebijakan sangat mempengaruhi proses implementasi kebijakan tersebut. Pemerintah Kota Yogyakarta menyadari hal itu sehingga sejak awal perumusan kebijakan serta aturan- aturan yang mendukung relokasi Pasar Talok sudah melibatkan komunitas pedagang pasar tersebut. Mereka diajak serta dalam proses perumusan bahkan sebelumnya kasus relokasi pedagang Klithikan, para pedagang diajak studi banding ke daerah lain yang sukses maupun tidak sukses dalam pelaksanaan kebijakan relokasi Pedagang.

Menurut Bapak Wuryanto salah satu staf Dinas Perdagangan Industri dan Koperasi Kota Yogyakarta mengatakan bahwa :

"Untuk melibatkan PKL dalam menyususn Petunjuk Pelaksanaan Perda 26/2002 mereka diajak study banding ke Surabaya dan Bali selama 5 hari. Adapun pengurus PKL yang diajak adalah pengurus PKL Wilayah Lempuyangan, PKM (Paguyuban Kawasan Malioboro) serta PPKLY (Persatuan Pedagang Kaki Lima Yogyakarta). Hal ini sangat membesarkan hati mereka 
karena mereka merasa diperhatikan oleh pemerintah. Ini merupakan sumbangan spigologis yang memudahkan para PKL berpartisipasi dalam menyusun petunjuk pelaksana Perda tentang PKL. Adapun studi banding di Surabaya untuk melihat bagaimana bila PKL ditata dengan kekerasan oleh Pemkot Surabaya karena mereka menolak ketika dilaksanakan kebijakan relokasi. Sedangakan keberadaan PKL di Bali untuk melihat PKL yang ditata.

Dari hasil studi banding tersebut proses dialog dalam penyususn Perda Penataan PKL dilaksanakan serta dilanjutkan dengan SK-SK Walikota yang menjadi pedoman pelaksanaan Perda berjalan dengan lancar. Perda inilah yang menjadi payung hukum sekaligus sebagai acuan dalam penataan PKL maupun pembuatan kebijakan relokasi para pedagang. Lebih lanjut Bapak Wuryanto menambahkan :

"Peran tim Penataan PKL yang beranggotakan Disperindakop, Dinas Ketertiban, Bagian Hukum, dan Kecamatan merupakan ujung tombak Pemerintah KotaYogyakarta dalam rangka penataan PKL. Kegiatan tim ini dimulai dengan perumusan bersama Paguyuban untuk membuat petunjuk pelaksanaan Perda 26/2002 dengan cara berembug dengan wakil dari pedagang dan paguyuban. Karena paguyuban tidak mampu membuat draf sehingga memberikan kuasa kepada pemerintah untuk membuat draf yang nantinya akan dibahas secara bersama-sama"

Berbagai peraturan pelaksanaan Perda tersebut yang dikelurkan dengan SK Walikota dan Peraturan Walikota yang menjadi dasar dalam melakukan kebijakan relokasi terhadap para PKL. Meskipun berbagai pendekatan persuasif yang dilakukan oleh pemerintah terhadap PKL dalam Penyusunan Perda dengan keterlibatan mereka dalam proses perumusan sampai dengan ditetapkan tetapi tetap masih menyisakan konroversi. Forum LSM meyakini proses pembuatan PERDA PKL dulunya kurang partisipatif dan tidak mengakomodir berbagai pihak sehingga kesannya pemerintahlah yang paling 
dominan dalam penyusunan Perda tersebut (Kedaulatan Rakyat, 16 Mei 2004)

Pada awal disahkannya PERDA ini memang menimbulkan banyak kontroversi yang terjadi di masyarakat namun PERDA ini tatap dilaksanakan dengan menata angkringan di Malioboro termasuk tendanisasinya. Pada pertemuan terakhir, pedagang angkringan memahami langkah penataan Pemkot dan ada bukti otentiknya, kata Walikota. Tetapi demo anti pengusuran dan penolakan pemberlakuan PERDA tersebut dihalaman DPRD (24/5) yang ditemui oleh Wakil Ketua DPRD Sukariyani yang mengatakan bahwa jika PERDA tersebut menyengsarakan maka dapat ditinjau kembali. Tetapi Pemkot tidak bisa begitu saja mencabut PERDA karena pada dasarnya Pemkot diberi amanah untuk mengawal Perda agar dilaksanakan dengan SK Walikota sebagai tindak lanjutnya. (Kedaulatan Rakyat, 25 Mei 2004)

Konsistensi Pemerintah Kota dalam Penataan PKL sudah terlihat dengan serangkaian kegiatan penertiban PKL yang berusaha di pinggir jalan yang dilarang untuk usaha PKL. Penataan Angkringan Malioboro (Maret 2004), Penataan Lesehan Malioboro (Mei 2004), Penataan Pedagang Alun-alun Utara (Juni 2004), dan Penataanpenataan PKL pada tempat- tempat lainya yang tidak sesuai dengan aturan akan ditindak tegas. Demikian Wakil Walikota mengatakan penataan ini bukan berarti melarang tetapi mengatur agar terlihat lebih rapai sekaligus memberikan kenyamanan pada penguna jalan. (Bernas, 22 Juni 2004).

Dengan diberlakukan PERDA 26/2002 maka dikeluarkanlah SK Walikota kemudian dipertegas lagi dengan SK Kadisperindakop dan Camat yang mengatur lokasi-lokasi yang diijinkan untuk usaha PKL. Setelah adanya kebijakan ini maka tidak ada lagi ijin baru bagi PKL kecuali tempat yang sudah ditinggalkan terdahulu berdasarkan surat Keputusan sebagai berikut :

1. Surat Keputusan Kepala Dinas Perindustrian, Perdagangan dan Koperasi Kota Yogyakarta Nomor 57 Tahun 2007 
tentang Penetapan Golongan Jenis Tempat Usaha dan Jenis Dagangan PKL Kota Yogyakarta.

2. Surat Keputusan Camat tentang Golongan jenis Tempat Usaha dan Jenis Dagangan Pedagang Kaki Lima di Kecamatan yang mengatur titik lokasi yang dijinkan untuk berjualan dilokasi masing-masing Kecamatan (Dwi Ariyanti Hardiyanti, 2008: 89).

Kewenangan ini dikonsultasikan dengan Disperindakop oleh Kecamatan supaya tercipta sinergi dalam pengaturan pedagang kaki lima, koordiansi ini berlangsung bila ada masalah di lapangan.

Dengan demikian adanya PERDA 26/ 2002 yang ditindak lanjuti dengan SK-SK Walikota akan memudahkan pemerinatah Kota untuk menata PKL selanjutnya. Peraturan- peraturan ini telah menjadi alat legitimasi terhadap penataan- penataan yang dilaksanakan oleh Pemkot, sehingga arah kebijakan relokasi Pasar Talok mempunyai landasan hukum yang jelas berdasarkan Perwal Nomor 31/DPA/SKPD/II/2007 tentang Pembangunan dan Penataan Pasar Talok. Dengan adanya Perwal tersebut maka kebijakan mempunyai legitimasi yang kuat sesuai dengan Perda 22/ 2002 meskipun protes dari masyarakat tetap ada.

\section{Pendekatan, Pengalaman Relokasi dan Alternatif Kebijakan}

Keberhasilan beberapa kebijakan relokasi yang pernah dilaksanakan oleh Pemerintah Kota Yogyakarta telah membuat aktor yang terlibat diberi amanah lagi untuk melaksanakan kebijakan relokasi yang lain. Hal yang menarik yang perlu dilihat dari berbagai kebijakan yang pernah dilakukan itu adalah pendekatan yang dipakai. Selama ini dalam proses penataan PKL pendekatan yang digunakan adalah pendekatan kemanusiaan sehingga Pemerintah Kota tidak menggunakan istilah "relokasi" atau "pengusuran" untuk menghindari konflik di masyarakat. 
Salah satu aktor yang terlibat dalam kebijakan relokasi ini menjelaskan ketika diwawancarai mengatakan bahwa :

"Pendekatan kemanusiaan disini di artikan sebagai seni dalam kepemimpinan yang situasional dengan melihat kondisi di lapangan, silaturahmi, pendekatan dengan guyonan (senda gurau). Proses yang disentuh terlebih dahulu hati dari objek kebijakan. Hal ini diterapkan dalam proses dialog dalam rangka penataan pedagang klithikan yang telah dilakukan. Konsep ini sebagaimana kultur Jawa yang mengajarkan untuk memanusiakan manusia. Pepata Jawa mangku (mendudukan orang dalam pangkuan kita) maka orang itu akan mati (menuruti kemauan kita)" (Hasil Wawancara dengan Bapak Sukirno).

Dari hasil wawancara dengan Bapak Wuryanto pada tanggal 01 Oktober 2010 diperoleh keterangan dan dari catatan notulen rapat bahwa pelaksanaan perumusan relokasi dilakukan secara intensif paska gempa bumi yang melanda DIY dan sekitarnya dengan agenda sosialisasi atau pendekatan dialog yang intensif untuk menjajagi kondisi pedagang. Mereka di undang dalam rangka dialog bersama eksekutif, DPRD dan komunitas masyarakat. Disisi lain, para pedagang yang pro terhadap relokasi mendesak pemerintah untuk segera melaksanakan relokasi kerana pelaksanaannya terus mengalami kemunduran. Sementara mereka yang menolak tetap dilaksankan dialog untuk mengajak berpikir supaya mau direlokasi.

Pedagang kemudian diajak berpikir untuk kebaikan mereka sendiri oleh Pemerintah Kota dengan mengadakan pertemuan antara pemerintah dengan pedagang. Dari cacatan notulen pemikiran untuk merelokasi para Pedagang Pasar Talok tersebut dilatarbelakangi oleh :

1. Aspek Legalitas Yaitu bahwa keberadaan para pedagang di lokasi baru nantinya akan mempunyai status hukum yang jelas (Pedagang Formal). Mereka sebagai pedagang pasar harus mempunyai Kartu Tanda Pedagang. 
2. Aspek Pemberdayaan yaitu bahwa dengan dengan dilakukan relokasi ke tempat yang baru akan difasilitasi oleh Pemerintah Kota sehingga pasar baru tersebut dapat tumbuh dan berkembang sebagai tempat usaha yang menjanjikan.

3. Aspek Ketertiban bahwa dengan dipindakannya para pedagang ke gedung pasar baru maka akan berdampak pada kelancaran lalulintas di jalan Tridarma, kebersihan dan ketertiban di lokasi pasar tetap terjaga.

4. Aspek Wisata yaitu dengan berkurangnya PKL yang akan dapat mewujudkan icon Kota Yogyakarta sebagai Kota Pariwisata sekaligus dapat mewujudkan slogan Yogyakarta Berhati Nyaman.

Peran pemerintah adalah untuk membuat kebijakan umum, sedangkan kebijakan khusus tergantung bagaimana proses komunikasi dijalankan. Secara prosedural, norma-norma birokrasi ditempuh untuk menghasilkan kebijakan yang ideal. Namun secara riil kadang-kadang dinamika masyarakat yang berkembang cepat menyebabkan pemerintah harus menghormati tuntutan masyarakat untuk memenuhi aspirasi mereka, sehingga terkesan kebijakan yang ada "by accident”.

Pada awalnya proses relokasi kebijakan yang baru pertama kali dilakukan oleh pemerintah akan menjadi laboratorium sosial yang mempunyai biaya tinggi sebagai model pertama tetapi murah pada model berikutnya. Hal ini terbukti dengan berbagai kebijakan relokasi yang pernah dilakukan seperti relokasi Pedangan Klithikan tahun 2007, relokasi pedagang Taman Sari ke Bringharjo lantai III (2008) dan relokasi Pedagang depan SD Pojokusuman (2008) yang semunya itu tanpa gejolak sama sekali (D.A Hardiyanti, 2008 : 92)

Model kebijakan kelompok mungkin merupakan pendekatan yang paling sesuai untuk melihat keberagaman komunitas dalam masyarakat yang menuntut untuk melakkukan relokasi terhadap keberadaan Pasar Talok yang di 
anggap sudah tidak sesuai lagi dengan perkembangan kota. Proses perumusan kebijakan ini merupakan upaya untuk menanggapi tuntutan dari masyarakat atau kelompok kepentinagan dengan cara bergaining, negosiasi dan kompromi, disinilah model mixed scaning digunakan sebagai referensi dimana di dalamnya terdapat keanekaragaman kolektifitas yang menuntut adanya masyarakat aktif yang terlibat dalam proses kebijakan untuk mencapai sebuah kompromi.

Dalam proses perumusan kebijakannya diawali dengan membentuk model kesepakatan bersama dalam bentuk tertulis supaya ada pengikat yang jelas antara hak dan kewajiban.

1. Membentuk semacam MoU antara pemerintah dengan komunitas pedagang dan masyarakat sekitar.

2. Adanya sebuah lembaga dari masyarakat yang digunakan untuk menjembatani dan menstrukturkan bahasa masing- masing pihak (LSM IMPLAW)

3. Adanya sentuhan psikologis dari aparat Pemerintah Kota untuk menempatkan diri sebagai pelayan bukan sebagai figur pribadi yang lebih ditonjolkan (Ibidem).

Dengan pendekatan sebagaimana di ungkapkan di atas, maka pembasan kebijakan antara pemerintah dan masyarakat serta komunitas pedagang akan lebih cair. Pemerintah Kota tidak menempatkan objek regulasi berbeda, tetapi mempunyai tingkat ketokohan yang sama bukan tingkat kelembagaan. Kedua belah pihak harus saling memahami proses yang berlangsung dan kepercayaan adanya keberpihakan pada masyarakat. Bila ada perubahan-perubahan yang terjadi merupakan bagian dalam mengukap realitas dan potensi yang maksimal.

Dalam proses pembuatan kebijakan ada beberapa unsur yang harus diperhatikan yaitu rasa tanggung jawab, resiko, inisiatif dan kesulitan-kesulitan yang dihadapi. berkaitan dengan hal tersebut, maka harus ada yang mau jadi driver untuk kebijakan tersebut. Untuk itu sejak awal dia sudah 
mewakafkan dirinya untuk menjadi driver dengan segala resiko yang mungkin dia akan di tanyakan kedudukannya sebagai apa sehingga harus mengatur lembaga atau instansi lain (Hasil wawancara dengan Bp Sukirno, 30/09/2010)

Kesulitan dalam proses perumusan kebijakan yang mungkin dihadapi adalah informasi yang tidak lengkap. Hal ini sudah di antisipasi dengan menyebar informan untuk mencari informasi terlebih dahulu oleh staf dari Dinas Pengelolaan Pasar untuk mendapatkan bukti-bukti yang ada di lapangan. Dengan adanya informasi yang didapat dari lapangan maka dapat digunakan sebagai referensi dalam proses perumusan kebijakan. Dengan langkah tersebut maka Pemerintah Kota dapat meyakinkan dan menyatukan pandangan dan keinginan para pedagang bahwa mereka mempunyai potensi yang bisa dikembangkan dengan cara meletakan mereka pada bidang dan tempat yang benar.

Kesulitan lain yang mungkin dihadapi dalam proses perumusan kebijakan adalah proses yang sulit dipahami. Dalam hal ini pemerintah Kota memerlukan suatu lembaga kemasyarakatan yang mampu menjadi jembatan struktur komunikasi sehingga kedua belah pihak saling memberi dan menerima. Dengan adanya bantuan LSM semacam IMPLAW yang telah terbukti melakukan penguatan kepada para pedagang selama ini maka proses perumusan kebijakan mudah dipahami oleh kedua belah pihak.

Dengan kesadaran dan kemampuan untuk membantu dari LSM, maka pemahaman bahwa Pemkot memihak kepada rakyat serta kepercayaan bahwa Pemkot akan memberikan penghormatan dalam memenuhi tuntutan masyarakat sangat membantuh dalam proses perumusan kebijakan dalam penataan pedagang.

Terkait dengan alternatif kebijakan relokasi Pedagang Pasar Talok yang di ilhami oleh berbagai pengalaman relokasi yang pernah dilakukan oleh Pemerintah Kota, pengalaman itulah yang menjadi pelajaran yang sangat berharga. Inilah yang menjadi feedback yang terintegral sehingga mengurangi 
kesulitan yang mungkin muncul dalam proses perumusan kebijakan.

Berbagai pengalaman relokasi yang pernah dilakukan terkait dengan kebijkan relokasi yang dilakukan oleh Pemerintah Kota Yogyakarta di antaranya. Pada tahun 2004 proses relokasi pedagang buah dan sayur di Shopping Center ke Pasar Buah dan Sayur Giwangan dimana LSM IMPLAW mencium bahwa Pemkot memecah belah komunitas di wilayah shopping center sebelum proses relokasi sehingga proses dialog tidak bisa berjalan sesuai dengan rencana yang diharapkan. Rencana dialog adalah dengan mendatangi masingmasing kelompok dan menegosiasi keberatan masing-masing yang mempunyai latar belakang yang berbeda. Maskipun proses ini ada banyak gejolak, tetapi Pemkot mendapatkan banyak pelajaran dari proses tersebut dan menjadikan konsep relokasi selanjutnya berganti (Wawancra dengan Bapak Sukirno, 30/09/2010)

Tahun 2005 Penataan Pedagang di Parkir Senopati untuk PKL sekitar wilayah Kilometer Nol dengan dibangunnya Kios Taman Parkir Senopati yang dapat menampung sebanyak 63 PKL yang terdata di wilayah depan Taman Pintar, Depan Kantor Pos Besar, Depan Gereja, Depan Kantor Bank Indonesia dan lingkungan Taman Parkir Senopati. Proses ini lebih mudah dan lebih mulus karena metode pendekatan dialog baik formal maupun non formal, siang dan malam secara intensif dilakukan sehingga hasilnya berjalan dengan baik dan dijadikan Pemkot sebagai referensi untuk konsep relokasi selanjutnya (D.A Hardiyanti, 2008: 96).

Konsep Penataan berikutnya adalah Wilayah Poncowinatan sebagai wisata Kaki Lima dan Kuliner. Namun masyarakat di sekitar keberatan karena takut kenyaman mereka akan terganggu dengan aktifitas malam yang akan berlangsung tetapi dengan pendekatan yang sudah dilakukan sebelumnya akhirnya konsep ini terealisir juga. Kemudian pada Tahun 2007 Kebijkan relokasi pedagang Klithikan ke Ex Pasar Hewan Pakucen yang pada awalnya banyak penolakan dari 
masyarakat maupun para pedagang namun akhirnya berhasil dilaksanakan tanpa gejolak (Ibidem).

Ini menunjukan bahwa pengalaman relokasi-relokasi yang telah dilaksanakan sebelumnya sangat penting untuk dijadikan sebgai pelajaran untuk kebijakan relokasi berikutnya. Meskipun rentang waktu dan situasinya tidak sama namun pendekakatan yang dilakukan tersebut menjadi acuan seperti dialog, sosialisasi dan penekatanpendekatan kemanusiaan yang lainnya. Pendekatan tersebut tetap menjadi senjata yang ampuh dalam mempengaruhi kemauan dan pandangan dari masyarakat ataupun para pedagang karena mereka merasa dihormati oleh pemerintah.

Terkait dengan kebijakan relokasi Pedagang Pasar Talok yang pada awalnya para pedagang menolak untuk direlokasi tetapi akhirnya berhasil dilaksanakan. Itu semua tidak lepas dari pendekatan kemanusiaan yang dilakukan oleh pemerintah lewat kecamatan Gondokusuman yang menjadi pioneer dalam keberhasilan tersebut. hal ini bisa dilihat dari hasil wawancara yang dilakukan dengan Bapak Baskoro selaku Kabid Pembangunan pada Bappeda yang mengatakan bahwa :

"Keberhasilan kebijakan relokasi Pasar Talok tidak lepas dari pendekatan yang dilakukan oleh Pemerintah terutama pihak Kecamatan yang melakukan berbagai pendekatan seperti dialog dengan komunitas pedagang dan masyarakat sekitar, sosialisasi secara rutin, dan pendekatan ketokohan lintas kewilayahan dengan masyarakat sekitar"

Lebih lanjut Sekretaris Kecamatan Gondokusuman, Agus Arif Nugroho menambahkan bahwa :

"Adanya pro dan kontra dari warga terhadap pembangunan pasar ini sudah muncul tahun 2006. Bahkan, saat itu gagasan relokasi berasal dari pedagang Pasar Talok itu sendiri. Kami tetap melakukan berbagai upaya sosialisasi bahkan melakukan upaya-upaya pendekatan yang bersifat ketokohan lintas wilayah dengan mendatangi para tokoh-tokoh masyarakat dan agama serta pemuda karang taruna untuk memberikan 
penjelasan kepada masyarakat agar mereka dapat mengerti dan memahami maksud dari kebijakan ini sampai akhirnya kebijakan ini bisa diterima dan dilaksanakan. Sekarang coba kita lihat ternyata lokasi di sekitar pasar sekarang menjadi pusat pertumbuhan ekonomi baru pedagang kecil yang setiap pagi harinya sangat ramai dengan pembeli" (Wawancara Bapak Agus arif Nugroho).

Ternyata berbagai pendekatan yang dilakukan diatas seperti sosialisasi dan dialog sejalan dengan misi Pemerintah Kota Yogyakarta menciptakan birokrasi pemerintah yang mampu menjadi fasilitator, inovator, motivator dan mediator yang handal di dalam kehidupan bermasyarakat, berbangsa dan bernegara. Proses relokasi Pasar Talok dari jalan Tridarma menjadi salah satu bukti dari kemampuan birokrasi dalam memainkan peranan tersebut.

Konsep perumusan kebijakan relokasi Pasar Talok merupakan desakan yang situasional dalam rangka memenuhi tuntutan masyarakat yang mendorong pemerintah untuk segera membuat kebijakan untuk menghidari jalan Tridarma dari kemacetan serta meminimalisir bertambahnya PKL di jalan tersebut. Permasalahan seperti kemacetan lalulintas, kenyamanan tinggal masyarakat sekitar, perparkiran yang tidak teratur, ketertiban dan kebersihan lingkungan akan menjadi lebih parah apabila kebijakan relokasi tidak ditempuh.

\section{Peran Media Massa dalam Perumusan Kebijakan}

Peranan media massa memang sangat mempengaruhi bagaimana kebijakan publik bisa diterima di masyarakat. Ketika media massa dapat "dikuasai" atau berpihak pada salah satu kelompok maka akan terjadi distorsi kebijakan publik tersebut dan energy yang diperlukan untuk melaksanakan kebijakan tersebut jelas lebih banyak yang harus dibutuhkan. Untuk itu hendaknya media massa harus independen dan berimbang dalam melakukan pemberitaan kepada masyarakat sesuai dengan fungsinya sebagai sarana informasi publik yang 
independen agar masyarakat dapat memahami realitas yang dihadapi olehnya.

Pada kasus relokasi Pasar Talok, media massa cukup seimbang dalam melakukan pemberitaan, hal ini tidak lepas dari peran Dinas Perindustrian, Perdagangan dan Koperasi yang menjadi leading sector "proyek" dalam menjalin komunikasi dengan para pencari berita dari berbagai media massa. Pertemuan dengan para jurnalis diadakan oleh Pemerintah Kota dalam rangka sosialisasi dan pembentukan opini tentang kebijakan relokasi ini dengan mengumpulkan para wartawan untuk dapat mensosialisasikan perkembangan yang ada. Bila ada berita yang tidak menguntungkan Pemkot, maka pemberitaan yang seimbang akan diberikan sebagai press release untuk dimuat sebagai counter berita utama (Wawancara dengan Bapak Wuryanto staf Disperindakop tanggal 01/10/2010).

Dengan mengumpulkan para jurnalis untuk mensosialisasikan maksud dari kebijakan ini harapannya berita yang dikeluarkan kepada masyarakat berimbang sesuai dengan kondisi dan situasi yang ada. Kesan yang selama ini terhadap pemberitaan media yang yang lebih memojokan kebijakan yang dibuat oleh pemerintah harus di tinggalkan sehingga masyarakat luas dapat menikmati pembangunan yang dibuat oleh pemerintah sekaligus pemerintah harus peka terhadap persoalan masyarakat dengan pemberitaan oleh media masa. Respon pemerintah terhadap aspirasi masyarakat yang menginginkan Pasar Talok segera direlokasi ke sebuah bangunan permanen itu tidak lepas dari peran media massa.

\section{E. Peran Legislatif dalam Perumusan Kebijakan}

Ide utama kebijakan relokasi Pasar Talok berasal dari masyarakat kemudian direspon oleh eksekutif dan legislatif di ajak untuk membahas kebijakan tersebut setelah disetujui barulah dibahas proses pentahapan anggaran pembangunan fisik pasar tersebut. Dalam pembahasannya, Dewan memberi masukan agar kebijakan tersebut dilaksanakan tanpa ada 
konflik atau gejolak dan sebisa mungkin diselesaikan dengan jalan dialog.

Peran anggota Dewan dalam kebijakan relokasi pedagang Pasar Talok diakui Bapak Zulnasri yang merupakan salah satu anggota Dewan dari Komisi B bahwa :

"Konsep kebijakan relokasi ini berasal dari eksekutif yang dalam proses pembahasan Dewan dilibatkan sampai dengan terealisasinya kebijakan tersebut. Konsep kebijakan ini relatif memadai dengan berbagai kepentingan baik dari para pedagang maupun dari masyarakat. Namun kita harus melihat bahwa keberadaan pasar tersebut cukup mengganggu aktifitas masyarakat terutama menyankut kemacetan pada jalan tersebut sehingga kita akan memberikan kawalan terhadap kebijakan ini. Apabila ada masyarakat yang tidak menyetujui kebijakan ini kita akan mewadai untuk menyalurkan aspirasi mereka" (Wawancara dengan Bapak Sinar).

Hal yang senada juga disampaikan oleh Bapak Zurif Hudaya selaku Ketua Komisi C DPRD Kota Yogyakarta terkait dengan ide awal relokasi tersebut sebagai berikut :

"Sesunggunya yang mempunyai ide relokasi adalah eksekutif yang kemudian di ekspose ke Dewan. Karena prosedur yang diajukan oleh eksekutif sudah sesuai dengan prosedur yang berlaku seperti sudah melalui penyusunan feasibility study (FS), kemudian penyusunan detail Engineering design (DED) dan di tenderkan dengan proses yang sesuai dengan peraturan yang berlaku serta tidak ada penyelewengan maupun penyimpangan, maka kami yang membawahi pembangunan dan pengawasan fisik dapat menyetujui dan mendukung kebijakan relokasi tersebut. Komisi $\mathrm{C}$ akan mengawal pelaksanaan pembangunan fisik dengan pantauan yang ketat terhadap kebijakan tersebut.

Dengan demikian jelaslah bahwa konsep kebijakan relokasi ini berasal dari pihak eksekutif sehingga pihak legislatif hanya memberikan pengawalan terhadap kebijakan tersebut. Apabila hal ini dibiarkan maka pasar tersebut akan 
semakin ramai sehingga tidak dapat terkendali lagi maka sepatutnya harus dibuat bagunan permanen untuk mewadahi para pedagang tersebut sehingga mereka tidak menggunakan jalan Tridarma sebagai tempat berjualan.

Kejelasan konsep relokasi ini harus jelas sehingga masyarakat dapat mempercayai Dewan sebagai kepanjangan tangan dari rakyat. Apabila proses perumusan kebijakan itu memakan waktu 2-3 tahun maka akan mempengaruhi perkembangan relokasi itu sendiri. Meskipun dengan keterbatasan anggaran yang dimiliki dalam pembangunan fisik pasar yang memerlukan waktu yang cukup lama tetapi Dewan harus tetap konsisten memberikan perhatian pada kebijakan ini.

Sebaik apapun kebijakan yang dibuat pemerintah pasti menimbulkan pro dan kontra dalam masyarakat karena tidak ada suatu kebijakan yang memuaskan semua pihak. Persetujuan dari Dewan terhadap kebijakan ini karena sudah sesuai dengan konsep pemberdayaan ekonomi pedagang (ekonomi kerakyatan). Legitimasi dari Dewan terhadap kebijakan ini harus benar-benar dikawal dalam proses perumusannya sampai dengan pelaksanaannya serta dapat memastikan kebijakan tersebut berjalan sesuai dengan rencana yang telah dibuat. Dewan juga harus membuka diri kepada masyarakat terkait dengan penolakan mereka terhadap kebijakan ini agar aspirasi mereka dapat tersampaikan kepada pembuat kebijakan untuk diselesaikan dengan baik.

\section{F. Peran Komunitas dalam Perumusan Kebijakan}

Peran Komunitas Pedagang Pasar Talok dan masyarakat sekitar sangat penting dalam proses perumusan kebijakan. Peran komunitas ini banyak terwakili oleh LSM IMPLAW (Indonesian Monitoring Prosudure of Law) yang sejak lama sudah menaruh perhatian pada kasus-kasus relokasi yang dilakukan di Yogyakarta. Meskipun kusus kebijakan relokasi Pedagang Pasar Talok tidak sebesar kasus relokasi Pedagang klithikan namun LSM IMPLAW tetap konsisten untuk memberikan 
perhatian dan penguatan terhadap masyarakat dan pedagang sekitar.

Proses relokasi Pasar Talok yang dilakukan secara damai tidak lepas dari peran LSM ini yang sangat anti dengan penggusuran. Proses penguatan terhadap para pedagang dilakukan dengan mengadakan berbagai diskusi sehingga tercipta suatu persepsi sebagai bekal untuk proses perumusan kebijakan dengan pemerintah. Keberhasilan relokasi ini juga karena LSM ini yang selalu berkomunikasi dengan pemerintah terkait dengan persoalan yang dihadapi oleh masyarakat sebelum dan sesudah relokasi dilaksanakan.

Untuk itu keberhasilan sebuah kebijakan sangat tergantung dari peranan seluruh stake holders yang terlibat dalam perumusan kebijakan tersebut. Jika masing-masing pihak tetap mempertahankan maksud dan kepentingannya maka tidak akan ada kompromi sehingga yang terjadi adalah dominasi atau hegemoni dari satu kelompok terhadap kelompok yang lainnya. Adanya konsistensi dari pemerintah untuk melakukan penguatan terhadap ekonomi lemah khususnya PKL serta adanya dukungan dari masyarakat menjadikan kebijakan ini dapat dilaksanakan dengan baik.

Dari uraian diatas dapat dibuat bagan ringkasan proses perumusan kebijakan Relokasi Pasar Talok sebagai berikut :

\section{Gambar 3. Perumusan Masalah}

\begin{tabular}{|c|c|}
\hline $\begin{array}{l}\text { Isu Kebijkan } \\
\text { - Perkembangan Pedagang Pasar } \\
\text { Talok } \\
\text { - Perkembangan Kota Yogyakarta } \\
\text { - Desakan Masyarakat sekitar dan } \\
\text { Pemerhati Kota } \\
\text { - Penertiban Parkir } \\
\text { - Kemacetan Jalan Tridarma } \\
\text { - Kebersihan Lingkungan }\end{array}$ & $\begin{array}{l}\text { Perumusan Masalah } \\
\text { - Merelokasi Pedagang Pasar Talok } \\
\text { ke dalam Kampung Gendeng di } \\
\text { samping Jalan Tridarma dengan } \\
\text { membuat Gedung yang permanan } \\
\text { bagi para pedagang agar mereka } \\
\text { merasa aman dan nyaman untuk } \\
\text { berjualan dan masyarakat sekitar } \\
\text { tidak terganggu }\end{array}$ \\
\hline
\end{tabular}

Ternyata perumusan kebijakan berasal dari desakan keadaan masalah yang harus diselesaikan. Apabila masalah yang timbul tersebut tidak di selesaikan maka Pemerintah Kota 
akan lebih banyak menanggung persoalan dan permasalahan yang akan mengikutinya. Kebijakan Relokasi Pasar Talok ini merupakan salah satu solusi yang tepat untuk memberikan penguatan terhadap sektor informal khususnya PKL sekaligus dapat memberikan kenyaman bagi pengguna jalan dan masyarakat sekitar. 


\section{BAB VI \\ PENUTUP}

Keberadaan pedagang kaki lima di Yogyakarta tetap dibutuhkan dalam meningkatkan pertumbuhan ekonomi dan mengurangi beban pemerintah dalam menyiapkan lapangan pekerjaan bagi masyarakat. Namun sering kali keberadaannya justru merugikan bagi beberapa pihak yang menganggap mereka sebagai sumber yang mengganggu ketertiban masyarakat dan kebersihan kota. Hal ini diperparah lagi dengan status mereka yang ilegal dikarenakan mereka menempati fasilitas-fasilitas umum yang tidak diperbolehkan oleh pemerintah. Menyadari akan hal itu maka Pemerintah Kota membuat Perda Nomor 26 Tahun 2002 tentang PKL untuk memberikan legitimasi bagi para PKL agar dapat melakukan aktivitasnya dengan tetap berkewajiban untuk mematuhi aturan yang berlaku.

Dari hasil kajian yang telah dilakukan terhadap kasus Relokasi Pasar Talok ini dapat disimpulkan sebagai berikut : 1) Kebijakan relokasi pedagang Pasar Talok ini merupakan usaha yang dilakukan oleh Pemerintah Kota Yogyakarta untuk memberikan perlindungan bagi para pedagang dari gangguan alam (hujan, panas) sehingga dengan dipindahkannya mereka pada bangunan yang permanen, maka harapannya mereka dapat melakukan aktivitas dengan baik dan nyaman. Selain itu juga kebijakan ini dimaksudkan untuk memfungsikan jalan Tridarma yang mengalami kemacetan sehingga mengganggu ketertiban dan kebersihan lingkungan masyarakat dan sekaligus juga kebijakan ini dilakukan untuk dapat meminimalisir bertambahnya PKL pada pasar tersebut. 2) Adapun pihak-pihak yang terlibat dalam proses perumusan kebijakan ini antara lain yaitu :

1. Walikota Yogyakarta

2. Kepala Badan Perencanaan Pembangunan Daerah Kota Yogyakarta.

3. Kepala Dinas Perdagangan Industri dan Koperasi Kota Yogyakarta. 
4. Kepala Dinas Pengelolaan Pasar Kota Yogyakarta

5. Camat dan Sekretaris Camat Gondokusuman

6. DPRD Kota Yogyakarta

7. Pedagang Pasar Talok dan Paguyubannya.

8. Masyarakat sekitar Pasar Talok

9. LSM IMPLAW (Indonesian Monitoring Prosudure of Law)

Proses perumusan kebijakan relokasi Pasar Talok diawali dengan adanya desakan dari masyarakat, pemerhati kota, dan keprihatinan terhadap kemacetan yang ditimbulkan oleh pasar tersebut. Kemudian Pemerintah Kota Yogyakarta merespon aspirasi yang berkembang di masyarakat dengan mengeluarkan Perwal Nomor 31/DPA/SKPD/II/2007 tentang Dokumen SKPD untuk Penataan dan Pembangunan Pasar Talok. Langkah selanjutnya Bappeda melakukan studi kelayakan terhadap pasar tersebut dan menyiapkan berbagai dokumen yang diperlukan untuk dibahas dengan masyarakat, pedagang dan LSM setelah ada kesepakatan kemudian kebijakan tersebut dibahas dengan Legislatif untuk memperoleh legitimasi dan persetujuan kemudian kebijakan tersebut mulai dilaksanakan. Dapat dipahami bahwa dalam proses pembahasannya dengan masyarakat pemerintah lebih menekankan pada pendekatan persuasif dengan cara melakukan diskusi yang intensif dengan masyarakat dan para pedagang yang menolak kebijakan tersebut, melakukan sosialisasi dan berbagai pendekatan lunak lainnya sehingga masyarakat dapat memahami maksud dari kebijakan tersebut. 


\section{DAFTAR PUSTAKA}

Burger, W. 1985. The Informal Sektor: Concept, Issues, and Policies. Institute of Social Studies Advisory Service, London

De Soto, Hernando. 2006. Meluruskan Banyak Pandangan Salah Kaprah. Yayasan Obor Indonesia, Jakarta.

Dunn, William. 1998. Pengantar Analisis Kebijakan Publik. UGM Press, Yogyakarta.

Dwidjowijito, Riant Nugroho. 2003. Kebijakan Publik, Formulasi, Implementasi dan Evaluasi. PT Elex Media Komputindo, Jakarta.

Dwidjowijito, Riant Nugroho. 2006. Kebijakan Publik untuk Negaranegara Berkembang, Model-model Formulasi, Implementasi dan Evaluasi. PT Elex Media Komputindo, Jakarta.

Eko, Sutoro (ed). 2005. Manifesto Pembaharuan Desa. APMD Press, Yogyakarta.

Hardiyanti, Dwi Ariyani. 2008. Kebijakan Relokasi Pedagang Klithikan (Studi Kasus di Pasar Klithikan Pakuncen Kota Yogyakarta. Tesis Pasca Sarjana MAP UGM, Yogyakarta.

Hartati, Sri, 2006. Dilema Sektor Informal. Kompas, Yogyakarta.

Hidayat. 1978. Pengembangan Sektor Informal dalam Pembanguan Nasional: Masalah dan Prospek. Pusat Penelitian Ekonomi dan Sumber Daya Manusia, Fakultas Ekonomi Universitas Padjajaran, Bandung.

Hidayat. 1988. Posisi dan Peranan Strategis Sektor Informal dalam Perekonomian Indonesia, Makalah disajikan Seminar "Mobilitas Penduduk dan Sektor Informal di Indonesia. PUA Studi Sosial UGM, Yogyakarta. 
Moleong, Lexy. 2001. Metodologi Penelitian Kualitatif. PT Remaja Rosdakarya, Bandung.

Nurcholis, Hanif. 2005. Teori dan praktik Pemerintahan dan Otonomi Daerah. Grasindo, Jakarta.

Pratikno, dkk. 2004. Mengelola Dinamika Politik dan Sumber Daya Daerah. Pascasarjana PLOD UGM, Yogyakarta.

Reni, Anastasia Purnama Sari. 2004. Dinamika Sosial-Politik Kebijakan Penataan Pedagang Kawasan Bringharjo (Studi Kasus terhadap Pedagang Kaki Lima (PKL) di Jalan Sriwedani. Tesis Pascasarjana Ilmu-ilmu Sosial UGM, Yogyakarta.

Riyadi, Soeprato. 2002. Pencermatan Peraturan Daerah No 26 Tahun 2002 tentang Penataan Pedagang Kaki Lima di Wilayah Kota Yogyakarta. Pemerintah Kota Yogyakarta.

Safi'i, H.M. 2008. Paradigma Baru Kebijakan Pembangunan Ekonomi Daerah. Averroes Press, Malang.

Singarimbun dan Effendi, Sofian. 1989. Metode Penelitian Survei, Edisi Revisi. Pustaka LP3ES Indonesia, Jakarta.

Soenarko. 2000. Public Policy: Pengertian Pokok untuk Memahami dan Analisa Kebijakan Pemerintah. Airlangga Univ. Press, Surabaya.

Subangun, Emmanuel. 1991. Sektor Informal di Indonesia Dari Titik Pandang Non-Akademik. Dalam : Prisma Politik Ekonomi Kaum Pinggiran. LP3ES, Jakarta.

Subarsono. 2005. Analisis Kebijakan Publik: Konsep, Teori dan Aplikasi. Pustaka Pelajar, Yogyakarta. 
Suharto, Eddi. 2005. Analisis Kebijakan Publik: Panduan Praktis Mengkaji Masalah dan Kebijakan Sosial. CV Alfabeta, Bandung.

Suharto, Eddi, 2006, Analisis Kebijakan Publik: Konsep Teori dan Aplikasi. Pustaka Pelajar, Yogyakarta

Swasono, Sri Edi dkk, 1986, Studi Kebijakan Sektor Informal, Laporan Penelitaian untuk Mentri Koordinator EKUIN. Kerjasama antara Pusat Penelitian Pranata Pembangunan Universitas Indonesian dan Lembaga Studi Pembangunan, Jakarta.

Triputro, R. Widodo. 2009. Kebijakan Publik. Materi Kuliah, Pasca Sarjana Ilmu Pemerintahan STPMD, Yogyakarta.

Wahab, Solichin Abdul. 1997. Analisis Kebijakan: Dari formulasi ke Implementasi Kebijakan Negara. Bumi Aksara, Jakarta.

Wahab, Solichin Abdul. 2002. Masa Depan Otonomi Daerah. SIC, Surabaya.

Wibawa, Samodra 1994. Kebijakan Publik Proses dan Analisis. Intermedia, Jakarta

Wibawa, Samodra. 2004. Reformasi Administrasi. Dalam: Pemikiran Administarsi Negara/ Publik. Geva Media, Yogyakarta.

Wibowo, Eddi. 2004. Kebijakan Publik Pro Civil Society. Yayasan Pembaruan Administrasi Publik Indonesia (YPAPI), Yogyakarta.

Widodo, Joko. 2007. Analisis Kebijakan Publik: Konsep dan Aplikasi Proses Kebijakan Publik. Bayumedia, Malang.

Winarno, Budi Surachman. 1982. Pengantar Penelitian Ilmiah, Dasar, Metode, dan Teknik.Toronto, Bandung. 
Winarno, Budi Surachman. 2007. Teori dan Proses Kebijakan Publik.

Media Pressindo, Yogyakarta.

Wiyano, Hasto. 2009. Outline Bahan Kuliah. Dalam: Matrikulasi Metodologi Penelitian Sosial. Pascasarjana Ilmu Pemerintahan STPMD, Yogyakarta.

\section{Referensi Lain}

Bappeda, 2007. Rencana Aksi Daerah (RAD) Pemerintah Kota Yogyakarta. Bappeda Kota, Yogyakarta.

Bernas, 25 Juli 2003. Inspeksi Mendadak Walikota. Yogyakarta.

Bernas, 22 Juni 2004. Penataan PKL di Kota Yogyakarta.

Yogyakarta.

Dinas Bangunan Gedung dan Aset Daerah. 2009. Dokumen Tentang Pekerjaan Pembangunan Pasar Talok. DBGAD Kota, Yogyakarta

Kedaulatan Rakyat, 16 Mei 2004. Forum LSM. Yogyakarta.

Kedaulatan Rakyat, 25 Mei 2004. Demo Anti Penggusuran. Yogyakarta.

Kedaulatan Rakyat, 26 April 2010. Peresmian Pasar Talok. Yogyakarta

Kedaulatan Rakyat, 02 Mei 2010. Pasar Talok Resmi Ditempati Pedagang. Yogyakarta

Kraton City PART II, 30 Maret 2006. Pedagang Pasar Talok Tolak Relokasi. Yogyakarta.

Pemerintah Kota, 2002. Peraturan Daerah (PERDA) Nomor 26 Tahun 2002 tentang Penataan Pedagang Kaki Lima. Yogyakarta 
Pemerintah Kota, 2009. Peraturan Daerah (PERDA) Nomor 03 Tahun 2002 tentang Pasar. Yogyakarta

Republika,09 Maret 2004. Tolak Penggusuran PKL. Yogyakarta. Wikipedia,

Indonesia, 2008, Pedagang Kaki Lima, Ensiklopedia

Bebas Berbahasa Indonesia, http://id.wikipedia.or/wiki/ pedagang_kaki_lima. 


\section{BIODATA PENULIS}

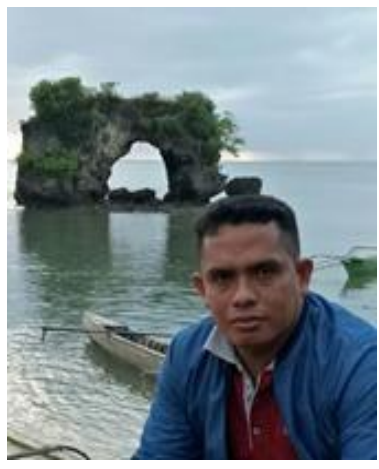

Amtai Alaslan, dengan sapaan akrab Bung Allan, lahir pada tanggal 18 Juni 1985 di Latdalam, Kabupaten Kepulauan Tanimbar, Maluku. Mengenyam pendidikan formal di SD Kristen I Latdalam dan lulus tahun 1998. Selanjutnya Ia meneruskan Sekolah Menengah Pertama di SMP Negeri 1 Tanimbar Selatan dan lulus pada tahun 2001, kemudian melanjutkan di pendidikan Menengah Atas di SMA Negeri 1 Tanimbar Selatan.

Setelah menamatkan SMA pada tahun 2004, Penulis melanjutkan studi pada jenjang Strata Satu (S1) Jurusan Ilmu Pemerintahan Sekolah Tinggi Pembangunan Masyarakat Desa "APMD” Yogyakarta dan Lulus tahun 2008 dengan Skripsi berjudul "Penerapan Prinsip- prinsip Goodgovenance dalam Pelayan Kesehatan".

Selepas meraih Gelar Sarjana Ilmu Politik, aktivitas Bung Allan lebih banyak dihabiskan untuk mengajar dan menjadi dosen tetap di Sekolah Tinggi Ilmu Adminstrasi Saumlaki (STIAS) sejak tahun 2008 hingga sekarang. Tahun 2009, Ia berkesempatan untuk melanjutkan studi S2 pada Alamamaternya yakni Program Pasca Sarjana Ilmu Pemerintahan STPMD “APMD” Yogyakarta. Hanya dalam waktu dua tahun (2011), gelar Magister Sains (M.Si.) diraihnya. Di bawah bimbingan Dr.Tri Nugroho, Ia merampungkan Tesis-nya yang berjudul "Kebijakan Relokasi Pasar Talok: Studi Kasus Tentang Relokasi Pasar Talok di Jalan Tridarma Gendeng Yogyakarta".

Dalam aktifitasnya sebagai Dosen tetap STIAS, Ia dipercayakan untuk menduduki Jabatan Struktural sebagai Wakil Ketua III Bidang Kemahasiswaan tahun 2012, tahun 2013 menduduki Jabatan Wakil Ketua I Bidang Akademik, pada tahun 2015-2020 menjabat sebagai Ketua STIAS kemudian saat ini Ia dipercayakan sebagai Kepala Lembaga Penelitian dan Pengabdian Masyarakat hingga tahun 2024.

Selain tugas sturuktural yang pernah diembannya, Ia banyak melakukan penelitian, baik dalam skala lokal maupun skala nasional. Tulisan-tulisannya telah dipulikasikan dalam jurnal 
OTONOMI (STIA Trinitas Ambon) dan AdBisPower (STIA Saumlaki). Pada tahun 2017, Penulis berhasil mendapatkan Hibah Penelitian Kompetitif Nasional melalui skema Penelitian Dosen Pemula dengan Judul "Analisis Nilai-nilai Duan Lolat Berbasis Kearifan Lokal Pada Masyarakat Tanimbar di Kabupaten Maluku Tenggara Barat". Pada saat ini, Penulis telah memperoleh jabatan fungsional akademik Lektor dalam kajian "Ilmu Politik dan Metodologi Penelitian Sosial Kualitatif" dan Penulis juda telah mendapatkan sertifikat sebagai Pendidik Profesional (Sertifikasi Dosen). Penulis dapat dihubungi melalui Alamat e-mail: bung_allan@yahoo.com atau alaslanamtai@gmail.com 